




\section{DARWINISM AND HUMAN LIFE}






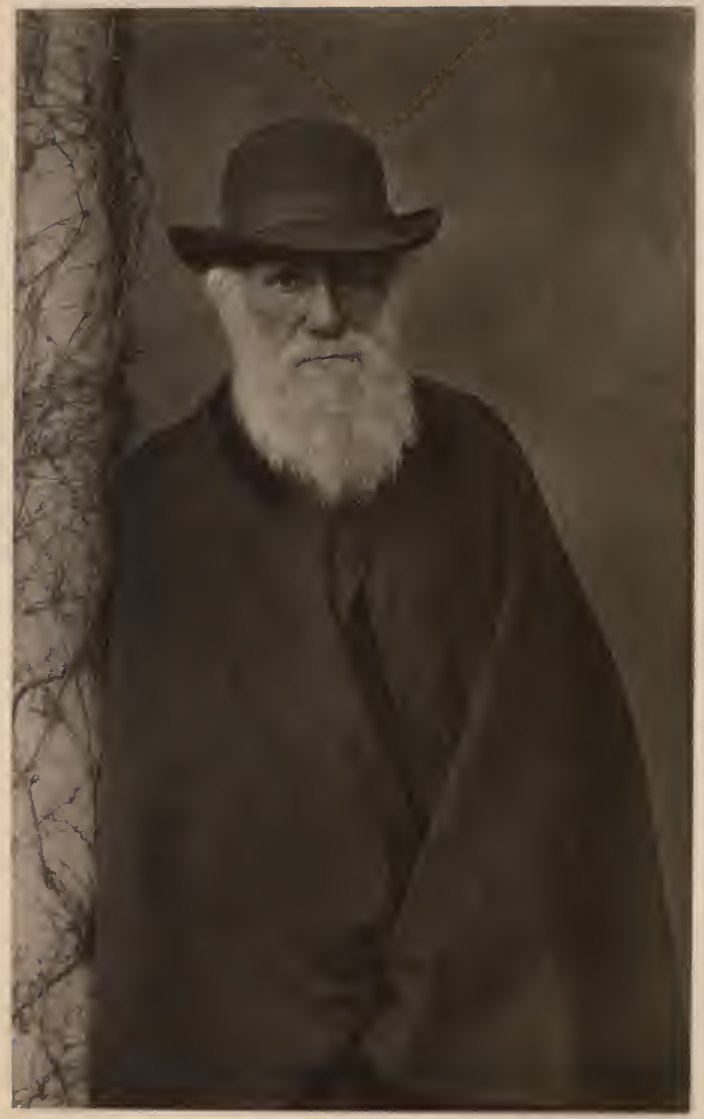




\section{DARWINISM AND HUMAN LIFE}

THE SOUTH AFRICAN LECTURES FOR 1909

B $\mathbf{Y}$

\section{J. ARTHUR THOMSON, M.A.}

Regius Professor of Natural History in the University of Aberdeen AUTHOR OF "THE STUDY OF ANIMAL LIFE," "THE SCIENCR OF LIFE," "OUTLINES OF zOOLOGY," "THE NATURAL HISTORY OF THE YRAR," "THR PROGRESS OF SCIENCE IN THE CENTURY," "HERBERT SPENCER," "HEREDITY," “THE BIBLE OF NATURE," ETC.; JOINT AUTHOR OF . "THE eVOLUTION OF sEx."

NEW YORK HENRY HOLT AND COMPANY LONDON : ANDREW MELROSE 
PRINTED BY HAZELL, WATSON AND VINEY, LD., LONDON AND AYLESBURY, ENGLAND. 



\section{PREFACE}

IN 1908 the Lecture Committee of the South African Association for the Advancement of Science did me the honour of inviting me to give the "South African Lectures" for 1909, and suggested that, in view of Darwin's Centenary, the subject of the course should be Darwinism. It was the chief aim of the lectures to explain the gist of Darwinism-what problems Darwin set himself to solve, and what solutions he arrived at, and to indicate what progress has been made as regards the problems of Organic Evolution since Darwin's day--what has been added to Darwinism, what, if anything, has been taken away, and, especially, what is now being reconsidered. An endeavour-necessarily straitened by the limits of the course-was also made to suggest how Darwinism touches everyday life, in farm and garden, in city and empire. 


\title{
CONTENTS
}

\author{
CHAPTER I \\ WHAT WE OWE TO DARWIN
}

Biographical-Darwin's Books-The Naturalist's Problems-The first Question: What is This ?-The second Question: How does This work ?-The third Question: Whence is This ?-The fourth Question: How have Present-day Organisms come to be as they are ?-Manifoldness of Darwin's Services-The Web of Life-The Struggle for Existence-Variability of Living Creatures-Natural Selection-Vindication of the Evolution Idea-The Evolution Theory, a Modal Interpretation-Darwin's Argument-Comparison of Evolution Formula and Gravitation Formula-The Descent and the Ascent of Man-Liberation of Intelligence-Ideal of Scientific Mood and Method-Characteristics of Scientific Mood : Passion and Reverence for Facts-Scientific Caution-Clearness of VisionSense of Interrelations-Darwin's Method of Working-Darwin on his own Success-Darwin's Achievements-Co-operating Influences -Particular Reasons for Darwin's Success . . . pp. 3-42

\section{CHAPTER II}

\section{THE WEB OF LIFE}

Correlation of Organisms as well as Correlation of Organs-What the Metaphor of "The Web of Life" suggests-Dependence of Living Creatures upon their Surroundings-Nutritive Chains-Nexus 
between Mud and Clear Thinking-Correlation between Catches of Mackerel and Amount of Spring Sunshine-Nutritive Chains in the Deep Sea-Dependence of one Organism on another for the Continuance of the Species-Darwin's Instance of the Connection between Cats and Clover-Scattering of Seeds-Interrelations between Freshwater Mussels and Fishes-Life-histories of Parasites -Far-reaching Influence of Certain Animals : Earthworms-Termites, or White Ants-The Hand of Life upon the Earth-Practical Importance of a Realisation of the Web of Life • - pp. 45-65

\section{CHAPTER III}

\section{THE STRUGGLE FOR EXISTENCE}

The Idea not so Simple as it seems-The Anthropomorphism of the Idea-Different Forms of the Struggle for Fxistence-Struggle for Existence in the Plant World-Illustration of the Complexity of the Struggle for Existence-Reasons for the Struggle for Existence -Results of the Struggle for Existence-Breadth of the Darwinian Concept of the Struggle for Existence-The other Side of the Struggle for Existence-Mutual Aid-Application of the Concept to Human Lifo • • • • • • • . pp.69-94

\section{CHAPTER IV}

\section{THE RAW MATERIALS OF PROGRESS}

Organio Progress Primarily depends on Variability-Darwin's Position-Progross since Darwin's Day in Regard to VariationVariations more Abundant than even Darwin supposed-Proportion between Frequency and Amount of Variations-Correlation of Variations-Brusque Variations more Frequent than was formerly supposed-Discontinuous Variations-Mutations-Darwin's Posjtion in Regard to Mutations-Origin of Variations-Germinal Seloction-Variational Stimuli-Modifications or Acquired Characters-Indirect Importance of Modifications-Modification-SpociosIndividual Plasticity-Relation to Human Lifo a pp. 97-126 


\section{CHAPTER V}

\section{FACTS OF INHERITANCE}

Progress during the Darwinian Era-Demonstration of Heritable Qualities-Heredity, a Term for the Genetic Relation between Successive Generations-Appreciation of Distinction between Nature and Nurture-The Idea of the Continuity of GenerationsCritical Attitude in Regard to Various Conclusions-MendelismMethods of Studying Heredity-Microscopical Study of the Germcells-Statistical Study: Filial Regression-Galton's Law of Ancestral Inheritanco-Experimental Study-Pairing of Similar Pure-bred Forms-Blending-Particulate Inheritance-Exclusive Inheritance-Reversion-Now Departures-Mendelian Inheritance -Unit Characters-The Case of Andalusian Fowls-Waltzing Mice -Occurrence of Mendelian Inheritance-Practical Importance of Mendelism-Much Progress but Great Uncertainty-Transmission of Acquired Characters-Diseaso-Facts and Possibilities-A Striking Case-Logical Position of the Question-Cases where the Theory of Modification-inheritance is Inapplicable-Importance of Environment and Function Remains-Selection and Stimulus-Indirect Importance of Modifications-Practical Import of the Question as to the Transmission of Acquired Characters-Inheritance of Moral Character-Three General Conclusions . . . . . . . . pp. 129-177

\section{CHAPTER VI}

\section{SELECTION : ORGANIC AND SOCIAL}

Influence of Malthus-Darwin's Position-The Theory statedThe Theory of Natural Selection to be tested as an Interpretative Formula-Illustrations of Natural Selection-Objections and Criticisms-Adaptations-Changes since Darwin's Day-Evidences of Natural Selection-Lessening the Burden of the Theory-Sexual Seleetion-Isolation-Gradual Diminution of Natural Selection in 
Mankind-Contrast between the Human Race and the Animel World-Some Natural Selection remains-The Dilemma of Civilisation-The extreme laissez-faire Position-Social Surgery-How far is Social Selection compensating for Diminished Natural Selection?Reversed Selection in Human Society-Summary of the ArgumentConstructive Suggestions-Selection of Eutopias-Selection of Healthful Occupations-Eugenic Selection. . . pp. 181-237

REPRESENTATIVE BOOKS ON DARWINISM - pp. 241-245 


\section{CHAPTER I}

\section{WHAT WE OWE TO DARWIN}





\section{CHAPTER I}

\section{WHAT WE OWE TO DARWIN}

Biographical-Darwin's Books-The Naturalist's Problems-The first Question: What is This ?-The second Question : How does This work ?-The third Question: Whence is This ? -The fourth Question: How have Present-day Organisms come to be as they are ?-Manifoldness of Darwin's Services -The Web of Life-The Struggle for Existence-Variability of Living Creatures-Natural Selection-Vindication of the Evolution Idea-The Evolution Theory, a Model Interpretation-Darwin's Argument-Comparison of Evolution Formula and Gravitation Formula-The Descent and the Ascent of Man-Liberation of Intelligence-Ideal of Scientific Mood and Method-Characteristics of Scientific Mood: Passion and Reverence for Facts-Scientific Caution-Clearness of Vision - Sense of Interrelations-Darwin's Method of WorkingDarwin on his own Success-Darwin's Achievements-Cooperating Influences-Particular Reasons for Darwin's Success.

BiograpHicaL.-Charles Darwin, the greatest naturalist who has yet lived, was born at Shrewsbury on February 12, 1809, on the same day as Abraham Lincoln. Indeed the year was one of remarkable children, for it saw the birth of Tennyson and Gladstone, of Chopin and Mendelssohn, of Mrs. Browning and Fanny Kemble, of Edgar Allan Poe and John Hill Burton, of Edward Fitzgerald and Oliver Wendell Holmes, and many more. We shall not compare Darwin with any of the illustrious personalities whom we have named, for the comparison of incommensurables is always unprofitable; but without exaggeration, which 
should be absent from scientific discourse, it may be said that no other man of science has influenced the framework of human thought as Darwin has done. We propose, first of all, to recall very briefly the leading facts of his life.

Darwin's inheritance must have given him a scientific bent. His grandfather, Erasmus Darwin, the author of " Zoonomia " (1794) was a thoughtful evolutionist; his father, Robert Waring Darwin, also a physician, had an unusually keen faculty of observation; his mother was a daughter of Josiah Wedgwood, the founder of the famous pottery works; and it may be further noted that Sir Francis Galton is Darwin's cousin. In addition to actual inheritance, there was another influence which would tend to direct Darwin's mind towards science, namely, the scientific atmosphere and tradition of his home.

As a boy Darwin was strong and active; he was fond of open-air life, and he made nothing of the classical school to which he was sent. In 1825 he went with his brother to Edinburgh with the purpose of studying medicine; but he found the lectures "intolerably dull" and made little of them. He got to know several naturalists, however, and made his first discovery-in regard to the development of the sea-mat (Flustra). After two sessions at Edinburgh he went to Cambridge with the vague view of becoming a clergyman; but of this period he writes: "During the three years which I spent at Cambridge my time was wasted, so far as academical studies were concerned, as completely as at Edinburgh and at school."

During his stay at Cambridge he kept up his boyish beetle-collecting and indulged his fondness 
for riding and shooting. $\mathrm{He}$ came under the influence of Professor Henslow, the botanist, who advised him to read Lyell's "Principles of Geology," and was instrumental in sending him off on the Beagle.

Of the Beagle voyage, which extended for five years (1831-6), mainly spent along the coasts of South America, Darwin says : " This was by far the most important event in my life, and has determined my whole career." He learned to work hard, he accumulated a wealth of impressions, and he had time to think. On one of his land journeys over the Pampas he was struck by the resemblances between living and extinct forms, and wrote: "This wonderful relationship in the same continent between the dead and the living will, I do not doubt, hereafter throw more light on the appearance of organic beings on our earth, and their disappearance from it, than any other class of facts." The savage character of the natives at Tierra del Fuego and the individuality of the fauna on the various Galapagos islands were seed-impressions which afterwards bore fruit in thought.

For six years after returning from the Beagle voyage, Darwin worked in London at his collections, especially at the geological specimens. He published his "Naturalist's Voyage" in 1839, and in the same year married his cousin, Emma Wedgwood. As his health had not been good after his return from the Beagle, he left London in 1842, and settled in a country house at Down. There in quiet industry, badly hampered by ill health, he spent the rest of his life. He died on April 19, 1882, one of the great Immortals among men.

Darwin's Books.-The forty years at Down 
were punctuated by the completion of book after book-the "milestones of my life," as he called them; and it may be useful to note that Darwin recognised three stages in his career as a biologist: (1) the mere collector at Cambridge; (2) the collector and observer on the Beagle voyage (to which he thought he owed " the first real training and education" of his mind); and (3) the trained naturalist after his eight years' work on barnacles.

His books may be arranged in three groups:

(a) The early zoological and geological studies, e.g. "Zoology and Geology of the Beagle" (184046), "Coral Reefs" (1842), "Monograph on the Cirripedia" (1846-54). Although the book on Earthworms was not published till 1881, it was begun more than forty years before, and may be included in the first series.

(b) The series of evolutionary volumes: "The Origin of Species" (1859); "Variation of Animals and Plants under Domestication" (1868); "Descent of Man" (1871); "Expression of the Emotions" (1872).

(c) The botanical books-largely influenced by evolutionary ideas: "Fertilisation of Orchids" (1862); "Movements and Habits of Climbing Plants" (1875); "Insectivorous Plants" (1875); "Cross and Self-fertilisation in Plants" (1876); "The Different Forms of Flowers in Plants of the same Species" (1877) ; " The Power of Movement in Plants" (1880).

The Naturalist's Problems. - It may be useful to inquire into the aims and methods of naturalists in general, if we are rightly to appreciate the services rendered by the greatest of them all. The problems appear at first sight to be numerous and 
varied, but, from a certain distance, we see that naturalists ask only four questions: What is this living creature? How does it work? Whence has it arisen? How has it come to be as it is ? Darwin asked each of these questions, but, after serving his apprenticeship in answering the first three-for he was anatomist, physiologist, and palæontologist in turn-he settled down to the fourth-the question of questions-How have living creatures come to be as they are?

The Question What is This? - The naturalist's first question-however learnedly he may phrase it-is one of the child's first questions, asked long before it can speak: "What is this?" In how many different tones - of fear, of awe, of wonder, of inquisitiveness-has this question been asked since man and science began! Was it not Aristotle's question when a new specimen was brought to him? Was it not the question of the naturalist on the Challenger when the dredge came up? Is it not the question on the lips of every teacher and student of natural history to-day?-What is this? It is a "simple question," but how hard to answer, as we press it further and further home, from external features to internal structure, from organs to tissues, from tissues to cells, as we put one lens after another in front of our own, as we call to our aid all sorts of devices-scalpel and forceps, razor and microtome, fixative and stain! "What is this," we say, "in itself and in all its parts? what is this by itself and when compared with its fellows and kindred ?", and our answer broadens and deepens till it furnishes the raw materials of the science of morphology. 
The Question How does This work?-But close upon the first question-What is this? there rises a second-How does this work? It is equally natural and necessary, and throughout the progressive periods in the history of biology the two questions have never been far apart. They have evolved together especially during the last hundred years, prompting one another to a more and more penetrating inquisitiveness. The key-word of the one is structure, or organisation; of the other function, or activity. The creature which our first question killed and picked to pieces has to be put together again and made to work. What does it do? how does it do it? how does it go ? how does it keep a-going? how does it set other creatures like itself a-going? how long can it go? how does it cease from going? In other words, how does the organism feel and move? how does it grow and multiply? how does it waste, recover itself, and finally, in most cases, die? Above all, what is the secret of its activity and of its power of effective response to the order of nature? These are some of the physiological problems which recall Clerk Maxwell's boyish question- "What is the go of this-the particular go of this ?"

The Question Whence is This? -A third question is-Whence is this? and, though it is probably as ancient as the others, the answering of it is distinctly modern. It is really a double question, for we may inquire into the development-the becoming-of the individual, and we may inquire into the history of the race to which the individual belongs. We may study the childanimal in its cradle-the bee-grub in the comb, the embryo skate in its mermaid's purse, the 
chick within the egg-shell-and the answer to the question-Whence came this individual animal as a whole and in each of its parts ? is embryology. On the other hand, we may study the history of the race as it is hidden in the strange graveyards of the buried past, the fossil-bearing rocks, and the answer to the question-Whence came this race? is palæontology.

The Question How have Present-day Organisms come to be as they are?-There remains a fourth question, also ancient, but since Darwin's day asked with a new hopefulness-How have these living creatures come to be as they are? They have had a history-a slow racial evolution-as surely as they have an individual development. We have got a firm grasp of the modal theory-that the present is the child of the past, but the causal theory is still being evolved. The idea of evolution is the most potent thought-economising formula which the world has yet known, but as to the factors in evolution we are still only inquiring. What are the originative and what the directive factors? How has the raw material of progress, which we call variation, been made available throughout the countless ages? and how has this raw material been fashioned to shape and use?

Manifoldnness of Darwin's Services.-What do we owe to Darwin? It is the meed of greatness to receive manifold tribute. For how many diverse reasons has Shakespeare the world's homage! A great life-work is like a great picture ; this character appeals to me and that to you. So some say that what we most owe to Darwin is our evolutionist outlook, while others emphasise the idea of selection, and others the demonstration that the problems 
of heredity and variation are amenable to scientific analysis, and others that he first clearly showed the affiliation of man to the rest of creation. The fact is that Darwin focussed so many ideas that were previously dim, and made so many old facts new, and gave us keys to so many doors, that it is a matter of opinion which of his services was greatest. This, at least, is certain: that, when we have thought for an hour of what we owe to Darwin, we shall not have discovered how much that is. For his intellectual legacy is still earning interest and increasing our wealth. His leaven will go on fermenting till the whole is leavened. Then it will be time for a new yeast.

(I) The Web of LIFE.-What do we owe to Darwin? We give precedence to Darwin's picture of "The Web of Life," the service that appeals most to the naturalist, to whom the conception is absolutely fundamental. It lies below the idea of the Struggle for Existence, and therefore below the idea of Natural Selection. It is a fact of life which will remain, however theories may change. It is a fine idea to dream over and to work with.

What is meant by Darwin's picture of the Web of Life, and where did he paint it? We find it in all his works-a luminous background-the idea of linkages in nature, the idea of the correlation of organisms. Cats have to do with the clover crop, Darwin says, and earthworms with the world's bread supply. If there is an orchid in Madagascar with a spur eleven inches long, Darwin prophesies that there is a moth with a proboscis of equal length. No bird falls to the ground without sending a throb through a wide circle, for Darwin rears eighty seedlings from a single clod 
taken from a bird's foot. Long nutritive chains bind the bracken on the hill-side to the brain of the proprietor-if he is fond of eating trout. The patent-leather shoes on his feet connect him with the melancholy slaughter of seals, while his ivory-backed toilet-brushes implicate him in the passing of the elephant. There is a ceaseless circulation of matter and energy. All things flow. Influence passes from A. to Z., though Z. is quite unaware of A. What ripples spread and spread from the introduction of rabbits into Australia, or of sparrows into the United States, or of the mongoose into Jamaica! What absolutely essential connections there are between cutting down trees and a plague of insects, between birds and seed-scattering, between sunlight and the catches of mackerel!

Take an instance from "The Origin of Species": "If certain insectivorous birds were to decrease in Paraguay, the parasitic insects would probably increase; and this would lessen the number of navel-frequenting flies-then cattle and horses would become feral, and this would certainly greatly alter (as indeed I have observed in parts of South America) the vegetation; this, again, would largely affect the insects ; and this, as we have just seen in Staffordshire, the insectivorous birds, and so onwards in ever-increasing circles of complexity."

(II) The Struggle for Existence.-What do we owe to Darwin? In the second place, we may rank his realisation of "the struggle for existence." From Aristotle to Lucretius, from Buffon to Robert Chambers, there had been allusion to the struggle for existence in nature, and every one knows, for instance, how it recurs repeatedly in 
Tennyson's "In Memoriam," which was written before "The Origin of Species." The poet speaks of Nature "red in tooth and claw with ravine"; "so careless of the single life"; "of fifty," or (as he afterwards suggested) "of myriad seeds she often brings but one to bear." But it is certain that no one before Darwin realised the length and breadth, the height and depth, of the struggle for existence. His realisation of it is " bigger " than that of most of his successors. Darwin recognised the struggle between Fellows, the struggle between Foes, and the struggle between Living Creatures and the Physical Forces. (A) There is cannibalism in the cradle in the egg-capsules of the buckie and the dog-whelk; locust may eat locust when the worst comes to the worst; stag may fight to the death with stag in the forest clearing; certain mountainvarieties of sheep will starve out other mountainvarieties; the sister seedlings compete together in the plot: that is Struggle between Fellows. We may extend this category of competition between individuals of the same species to include competition between individuals of nearly related species, though what is involved in the step should be carefully noticed. If we make the extension, however, we include Darwin's well-known case of brown rat versus black rat. The other illustrations he gave concerned two kinds of thrush, two kinds of swallow, two kinds of cockroach, and two kinds of charlock. (B) Secondly, the world is full of competition and struggle between living creatures not nearly related to one anotherbetween fox and hare, between stoat and rabbit, between mongoose and snake, and so on, end- 
lessly: that is Struggle between Foes. The foes do not need to be well matched. Alfred Russel Wallace has recently told us of a pair of blue tits, with a large family, who worked for sixteen hours a day at midsummer, and it was estimated that they captured in that time about two thousand caterpillars and grubs. A locust-bird at work is another good instance of a one-sided struggle. Nor do the foes need to compete directly-it will suffice if both seek the same food, the same locality, the same anything. third great mode of the struggle for existence when he spoke, for instance, of a plant on the edge of the desert struggling for life against the drought, and of the birds struggling against the winter. This is the Struggle with Fate.

As a number of illustrious living naturalists persist in maintaining that what Darwin mainly thought of was the struggle between near kinfor room in the nest, for food at the platter, for foothold on the rock, and so on, we must remember Darwin's emphatic statement that he used the term "in a large and metaphorical sense." He speaks of two "canine animals" struggling with each other in a time of dearth; of mistletoe versus mistletoe on the same branch; of mistletoe versus other fruit-bearing plants; of a plant on the edge of the desert in days of drought; and then says, "In these several senses, which pass into each other, I use, for convenience' sake, the general term of Struggle for Existence." The fact is that the "struggle for existence" is a formula-phrase including all the reactions and endeavours of living creatures in face of difficulties and limitations. 
(III) Variability of Living Creatures. - What do we owe to Darwin? A vivid presentation of the idea of variability, or organic flux. There had been, of course, transformists before his day, but either they had not the idea very clearly in their own minds or they failed in making it convincing to others. So it was that Darwin had to make way against the general conviction of contemporary naturalists that species were fixed. In 1844 he wrote to Hooker : "I am almost convinced ... that species are not (it is like confessing a murder) immutable." The idea seems to have suggested itself more than once on the Beagle voyage; for instance, when he found fossils in Argentina very like living forms and yet different.

In forming his impression of the variability of living creatures Darwin depended on what has taken place in domestication and cultivation, on the experience gained in his systematic work that specific characters are far from being constant, and that so-called varieties often link species to species. A species is a group of similar individuals of common descent, capable of pairing together, and breeding more or less true. It may be represented by a constellation of dots, densest towards the centre (which means that the great majority are very like one another) and thinning out towards the periphery where the variants extend as outliers in different directions. When we begin to study a corner of the zoological sky it seems to be covered with very distinct constellations, and it is all clear; but in many cases deeper study shows that one constellation is connected with another by outliers, and that there is continual flux. 
Darwin recognised the occurrence of structural changes directly due to changed surroundings and changed habits, which he called "definite variations," which are now usually called modifications, or "acquired characters"; and he believed that these were, in some cases, transmitted. This is the characteristic Lamarckian position. But the raw materials of progress which Darwin chiefly relied on were what he called the " numerous, successive, slight, favourable variations" ("Origin of Species," p.421). He also took account of "sudden and considerable deviations of structure "-_" single or occasional variations," as he called them; but he very deliberately refrained from attaching importance to such leaps and bounds, thinking that they had no staying power in inheritance. As to the causes of the inborn variations in living creatures, Darwin had no light, and, with his characteristic candour, said so.

(IV) Natural Selection.-What do we owe to Darwin? The theory of Natural Selection, which his magnanimous fellow-worker, Alfred Russel Wallace, independently stated at the same time (1858), and of which there had been a few previous suggestions of a more or less vague description. It was here that Darwin's originality was greatest, for he revealed the many different forms-often very subtle-which Natural Selection takes, and, with the insight of a disciplined scientific imagination, he realised what a mighty engine of progress it has been and is. His theory is simple and admits of brief statement. We can understand Huxley's remark: "How extremely stupid not to have thought of that!"

(1) Variability is a fact of life. The members of 
a family or of a species are not born alike : some have qualities which give them a little advantage both as to hunger and as to love; others are relatively handicapped. We may not understand their origin, but we know that useful variations occur.

(2) A struggle for existence is also a fact of life-a struggle for existence in an intricate web of interrelations. It operates whenever there is disturbance of equilibrium or clashing of interests, whenever the living creature makes effective responses to the limitations closing in upon it.

(3) In certain forms of the struggle for existence the relatively less fit forms are eliminated, which does not necessarily mean that they come at once to a violent end, but often simply that they die before the average time and are less successful than their neighbours as regards their offspring. The result is that the relatively more fit tend to survive, and to become the majority. The fitness may refer to the whole constitution, or to a particular character.

(4) As many variations are transmitted from generation to generation, and may, through the pairing of similar or suitable mates, be gradually increased in amount, the eliminative or selective process, if discriminate, consistent, and sustained, will work towards the establishment of new adaptations and new species. Natural Selection is Nature's process of singling and sifting for parenthood by the discriminate elimination of the relatively less fit to the given conditions.

Take, in the meantime, just one illustration. In Dublin Bay there is a sandy island, about 120 years old. It is frequented by a light-coloured 
variety of mouse which burrows in the sand. It seems reasonable to interpret the prevalence of this inconspicuous sand-coloured variety as due to the elimination of the ordinary darker mice by birds of prey.

Wallace asks the interesting question: Why, after many had failed, did Darwin and he find the same solution of the riddle of progress, namely, in Natural Selection? He points out that they had certain experiences in common : (1) as ardent beetle-hunters from their youth up, they were both accustomed to study minute details and varieties, and they thus had a trained eye for individualities; (2) they both had a speculative turn of mind, and were fond of trying solutions ; (3) they both enjoyed the wealth of impressions that travel gives, and the boon of solitude and quiet in which to "attend their minds unto" the problem that "haunted" them; and (4) both had read Malthus. Perhaps one might add that both had realised the selective processes implied in the keen competitive conditions of their time.

(V) Vindication of the Evolution Idea.What do we owe to Darwin? The first successful vindication of the evolution idea. It was not his own, nor was he its first champion, yet we always, and rightly, think of Darwin and the Doctrine of Descent together. He made it current coin of. the intellectual realm. He made the nations "think in terms of evolution."

The central idea of evolution is that the present is the child of the past and the parent of the future. It is the idea of progressive change from phase to phase without loss of continuity. A process of Becoming leads to a new phase of 
Being-whether in solar systems or in social institutions or in living creatures. But in the first the continuity is sustained in identity of substance, in the second by tradition and social registration, and in the third by the hereditary linkage of successive generations.

"Stated concretely, in regard to living creatures, the general doctrine of descent suggests, as we all know, that the plants and animals now around us are the results of natural processes working throughout the ages; that the forms we see are the lineal descendants of ancestors on the whole somewhat simpler, that these are descended from yet simpler forms, and so on backward, till we lose our clue in the unknown-but doubtless momentous-vital events of pre-Cambrian ages, or, in other words, in the thick mist of life's beginnings." 1

"As in the development of a fugue," Samuel Butler says, "where, when the subject and countersubject have been announced, there must thenceforth be nothing new, and yet all must be new, so throughout organic nature-which is a fugue developed to great length from a very simple subject-everything is linked on to and grows out of that which comes next to it in order."

The evolution idea is not only essentially simple, it is also very ancient. It is as old as Aristotleand older. It is perhaps as old as clear thinking, which we may date from the unknown time when man discovered the year, with its marvellous object-lesson of recurrent sequences, and realised that his race had a history. Whatever may have

1 "The Study of Animal Life," by J. Arthur Thomson. (Murray, London.) 
been its origin, the idea was familiar to several of the ancient Greek philosophers, as it was to Hume and Kant; it fired the imagination of Lucretius and linked him to Goethe; it persisted through the ages of other than scientific preoccupation; it became a concrete theory of the transformation of species in the hands of the pioneers of modern biology-such as Buffon, Lamarck, Erasmus Darwin, and Treviranus; and it became current intellectual coin when Charles Darwin, Alfred Russel Wallace, Herbert Spencer, Huxley, and Haeckel, with united but varied achievements, won the conviction of most thoughtful men.

The Evolution Theory a Modal InterpreTATION.-It must be carefully noted that the general idea of organic evolution is a modal interpretation of the history of the animate world. It suggests the mode by which organisms have come to be as they are. It says that the mode is scientifically decipherable, and is comparable to what we see going on in the origin of new breeds of pigeons or new varieties of wheat. But what other view is there? We do not know of any other scientific view, and the only alternative is to maintain that the mode of origin of the various kinds of living creatures is undecipherable scientifically, and cannot be formulated except in transcendental terms, such as Creation. The general view when Darwin published the "Origin of Species" was Creationist, or, if the naturalist fought shy of such words, the Linnæan dogma of the Fixity of Species was accepted and the question of origin was regarded as hopeless. Much will be gained if we clearly understand 
that the theory of evolution suggests a modal interpretation within the scientific universe of discourse, while the other view gives up even the possibility of scientific re-description, and suggests a transcendental formula as alone possible. It is quite certain that there is no manner of use in pitting a scientific formula against a transcendental one: that always means a false antithesis and intellectual fog. They are incommensurables. The true antithesis is between a scientific interpretation and maintaining that it is impossible to give one.

There is an intricate, beautiful, rational pattern before us in nature : are we to think of it as woven, thread by thread, by invisible hands in a way past finding out scientifically; or was there so much mind put into the original institution of things-an apparently simple loom-that thenceforth the web has been worked out automatically in a manner that admits of scientific formulation? When we finally discover that the doctrine of descent and all the theories of evolution do not fundamentally explain what they formulate, ${ }^{1}$ we

1 This expresses the common view that science is re-description in "simpler terms"-which, however, are not themselves "explained." In regard to complexities such as development and behaviour we formulate sequences, but we cannot flatter ourselves that our notations are more than symbols of the realities. In his "L'Èvolution Créatrice," Prof. Henri Bergson states this position (which he does not hold) in the following sentence: "Ce n'est plus la réalité même, dit-elle, qu'elle recomposera, mais seulement une imitation du réel, ou plutôt, une image symbolique; l'essence des choses nous échappe et nous échappera toujours, nous nous mouvons parmi des relations, l'absolu n'est pas de notre ressort, arrêtons-nous devant l'Inconnaissable." For an exposition of this scientific position see "The Bible of Nature," by J. Arthur Thomson (1908). 
shall be able, perhaps, to return to the transcendental formula with intelligence.

In regard to the proposition that science offers not explanations but formulations, it is important to bear in mind (1) that the biologist, for instance, postulates simple living creatures with which to start his story of evolution; (2) that he also takes for granted throughout the organism's power of varying and trading with time; (3) that he does not account, as yet, for the "big lifts " in the process of evolution, or for the direction in which the tree has grown (vertically, so to speak, as well as horizontally)-a direction which gives the whole process greater significance; and (4) that the biologist's causal equation is not like those of mechanics, where causa aequat effectum. Bergson distinguishes (a) a cause acting par impulsion, as when one billiard-ball strikes another (where the quantity and quality of the effect vary with the quantity and quality of the cause); (b) a cause acting par délanchement, as when a spark makes the powder explode (where the invariable effect has no relation to the quantity and quality of the cause); and (c) a cause acting par déroulement, as when the spring which works the gramophone unrolls the tune on the cylinder (where the quantity of the effect is proportionate to the quantity of the cause). In the first case only does the cause explain the effect, but living is not such an effect.

Darwin's Argument.-What did Darwin reall.ido in regard to the general doctrine of org-iains evolution? He showed that it rationalisereloped whole outlook. He took a wide sweep. to visible as they are and showed that they aiy small ves- 
lutionist interpretation. There are no locks which its key does not fit. As there is often misunderstanding in regard to the so-called " evidences of evolution," we must note that Darwin's magistral work was not of the nature of an induction leading up to the doctrine of descent as its conclusion. It was a deductive vindication of the doctrine that he gave us-" a cumulative justification showing how well the formula fits a vast series of facts." We cannot agree with the statement that Darwin proved in 1859 what Lamarck had only suggested fifty years before, ${ }^{1}$ for there is no logical proof of the doctrine of descent. It must be allowed, however, that Darwin's illustrationswhat some would call his cumulative evidencewere so carefully chosen that they left few openings for effective criticism. The basis of fact which the formula was shown to fit was solid, broad, and representative.

(a) Darwin pointed to the evolution which is going on in domesticated animals, such as sheep and cattle, and in cultivated plants, such as cabbages and apples, and used the argument: If Man has been instrumental in fixing all these varieties in a short time, what may not Nature have effected in a very long time? This line of argument has been greatly strengthened of recent years by cases like De Vries's mutations of the Evening Primrose (Enothera lamarckiana).

- (b) There is significance in the broad fact that l'e is possible to arrange the animal kingdom in nous povisional genealogical tree, showing stages of this scicessive organisation from lower to higher Thomson (1九 . "Philosophie Zoologique" was published in 1809, $\checkmark$ born. 
forms. When we take a particular group of animals it is often possible to draw that branch of the genealogical tree with a firmer hand, for it is the mutual relations of the large series which are so difficult. From the actual classification of organisms, from the peculiar way in which the categories are related one within the otherspecies, genera, families, orders, classes-we get an impression of affiliation which we do not get from a classification of rocks or other inanimate objects.

(c) Darwin attached great importance to the anatomical evidence of adherence to general type in spite of the most manifold diversity in external form. If we take, for instance, a series of forelimbs among Vertebrates-the arm of a frog, the paddle of a turtle, the wing of a bird, the fore-leg of a horse, the flipper of a whale, the wing of a bat, the arm of man-we find a detailed homology not only as regards the bones, but as regards muscles, nerves, and blood-vessels. It is difficult to suggest any interpretation except that the resemblance is due to relationship. As Darwin said: "How inexplicable is the similar pattern of the hand of a man, the foot of a dog, the wing of a bat, the flipper of a seal, on the doctrine of independent acts of creation! How simply explained on the principle of the natural selection of successive slight variations in the diverging descendants from a single progenitor!"

(d) Darwin made a good case out of rudimentary or vestigial organs-the dwindling remains of structures which were presumably well developed in ancestral forms. Cetaceans have no visible hind-limbs, but many show relatively small ves- 
tiges buried deep below the surface. The whalebone whale has two sets of teeth which never cut the gum, their place being taken by baleen plates. The New Zealand Kiwi has minute traces of wings, the limbless slow-worm has a rudimentary pectoral girdle, man has scores of vestiges, such as the third eyelid or the ear-moving muscles. Darwin compared these vestiges to the unsounded letters in many words, such as the "o" in leopard, the " $\mathrm{b}$ " in doubt, the " $\mathrm{g}$ " in reign, which are quite functionless, but tell us something about the history of the words.

(e) It is a simple but eloquent fact that the geological record in the fossil-bearing rocks shows the gradual appearance of higher and higher forms. At a certain stage in the history of the earth all the animals were Invertebrates; then fishes appeared, then amphibians, then reptiles, then birds and mammals. As the ages have passed, life has been slowly creeping upwards. The rock-record corresponds in its sequences with those deducible from comparative anatomy and embryology.

Furthermore, the rock-record reveals quite a number of connecting links, such as Archocopteryx, the oldest known bird, which has some distinctly reptilian features, and a larger number of generalised types, such as Phenacodus, one of the ancestors of the horse lineage, which bind together several subsequently specialised families, or even orders.

In certain cases, where fossils have been obtained from successive strata, the palæontological series is wonderfully complete, and the various stages in the evolution of tooth, or limb, or shell appear like the stages in individual development. 
Thus there is convincing completeness in the series uniting various species of the freshwater snails, Paludina and Planorbis, and various types of Ammonites. In the same way the remarkable series of fossil horses, elephants, and crocodiles, are either records of pedigree or conundrums.

$(f)$ The development of the individual is often in some measure interpretable as a condensed recapitulation of the presumed racial evolution. The individual, as Prof. Milnes Marshall said, climbs up its own genealogical tree. Ontogeny tends to recapitulate phylogeny, especially as regards the stages passed through by a particular organ, such as the brain or the heart. In their early stages there is a remarkable resemblance between the embryos of the higher Vertebrates: they seem, as it were, to travel for some distance along the same road before they diverge on their several paths. Gill-slits occur in the development of the embryos of reptiles, birds, and mammals, although they have no respiratory significance and are not of any use at all except that one seems to become the Eustachian tube connecting the ear with the back of the mouth. The young tadpole of the frog is fish-like in many details, e.g. as regards the heart and circulation. The very unsymmetrical flat fishes, such as flounder and sole, pass through a symmetrical stage. In Fritz Müller's "Facts for Darwin" the recapitulation idea was applied in detail to Crustaceans, and it seems impossible to understand the often very circuitous development unless it has an historical significance.

(g) The facts of geographical distribution in past and present suggest the gradual dispersal of 
races from centres where they had their original headquarters. Peculiar cases, such as the presentday distribution of Camelidæ, or the fauna of Australia, or the population of oceanic islands, readily admit of evolutionist interpretations.

We have not given prominence to the so-called evidences of evolution, partly because they have been stated so often-e.g. by Romanes and by Milnes Marshall-partly because none of the socalled evidence is in itself demonstrative in the strict sense. All that is shown is that the formula fits a wide and representative series of facts, and enables us to think of them in a clear and rapid way. What can be securely said is this, that all biological facts can be used as evidence of evolution if we know enough about them, and there are no biological facts which are inconsistent with it, so far as we know.

Comparison OF Evolution Formula AND Gravitation Formula.-Let us compare the evolution theory with one of the great physical generalisations-the gravitation formula. Both are simple in statement, both are wide as the world in their applicability. We are aware of no facts contradictory to either. Furthermore, they are alike in this, that neither proposes any ultimate explanation, that both are examples of intellectual shorthand, of thought-economising, descriptive formulæ. We do not know why one body attracts another in the manner which Newton formulated; we do not know why life should have its power of slowly creeping upwards. It has been pointed out that, just as Newton started with gravitation as a big fundamental fact, so Darwin started from variation, 
and that both left their fundamental assumption from experience unexplained.

But there is this difference between the gravitation formula and the evolution idea, that the experimental vindication of the first is easy, while that of the second is, to say the least, extremely difficult. Whether we study the apples falling in the orchard or the planets in their courses, we can continually confirm the accuracy of the gravitation formula, to which two centuries have not added anything essential, from which two centuries have taken nothing away.

But the evolution doctrine does not rest on a foundation of this sort. Like wisdom, it is justified of its children-by half a century's using-and to speak of proving it is to misunderstand it.

Before passing from the general idea of organic evolution we must point out that it is no mere doctrine of the schools, but an important human asset-of practical and emotional, as well as of intellectual value. In accepting the evolution idea we lose no small part of its virtue if we do not visualise it, if we do not, in some measure, image the relative simplicity of life's beginnings and the long pageant that has passed in gorgeous procession over the earth for millions of years; if we do not understand that evolution is going on still and that it includes us and our doings in its sweep. ${ }^{1}$

1 Émile Ferrière illustrates 'the theory of organic evolution very clearly by drawing a parallel between species and languages.

A language may have many varieties, just as a species often has. In both cases there is evidence of slow transformation and of demonstrable pedigrees. Changes may be observed in actual occurrence alike in languages and in organisms. It is possible in both to distinguish changes arising from within (intrinsio varia- 
(VI) The Descent and Ascent of Man.What do we owe to Darwin? A recognition of man's solidarity with the rest of creation, of his affiliation to a Simian stock. In the cumulative argument of the "Descent of Man," Darwin disclosed the rock whence he was hewn and the pit whence he was digged, showing, not exactly that " man sprang from a monkey," as the vulgar idea is, but that man and anthropoid apes are collateral branches from a common Primate stock which remains hidden in obscurity.

Darwin gave details of the all-pervading similitude of structure between man and the anthropoid apes, to which the researches of recent years have added such striking items as a sameness in blood-reaction to Friedenthal's test. He showed how we carry about with us a museum of relics indicative of our ancestry-a museum whose catalogue now amounts, according to Wiedersheim, to about a hundred items. The anatomical resemblances between adult man and adult apes are associated with even closer resemblances in the embryos, and gain additional significance when we take into account the scanty skeletal remains of primitive man, the lower races of men, and the occurrence of almost sub-human types occasionally born in times of distress. The affiliation applies to mind as well as body, for there is an ever-growing mass of tions) from changes imposed from without (extrinsic modifications). Young stages of a language show embryonic features, just as languages that have been evolving for centuries show vestigial structures, such as the familiar unsounded letters in words. There are fossil languages, just as there are fossil species. Both in languages and in species we can recognise the operation of selective processes and the effect of isolation, 
facts relating to peculiar psychoses in child and adult which we must recognise as vestigial and recapitulatory. ${ }^{1}$

Those who feel a repugnance to the Darwinian conclusion that man is descended from a humble Simian ancestry should remember the marvellous ascent in each individual lifetime. Neither the dignity nor the value of a result is affected by the historical conditions of its becoming. And if man is separated off by reason (or the power of conceptual inference), by morality (or the habit of controlling his conduct in reference to ideals), by the possession of true language or Logos, and by other qualities distinctively human, then we must increase our respect for, and see more in, that brute creation which contained the potentiality of all. For it is a fundamental idea of evolution that there is nothing in the end which is not also in the beginning.

(VII) IIberation of Intelligence.-What do we owe to Darwin? A great liberation of the intelligence. Like Abraham Lincoln, who was born on the same day in the same year, Darwin worked for freedom, though perhaps without ever thinking of it. As Prof. H. E. Crampton has said: "The 'Origin of Species' has proved a veritable Magna Charta of intellectual liberties, for, as no other single document before or since, it has released the thoughts of men from the trammels of unreasoned conservatism and dogmatism." Speaking of his first impressions of the "Origin

1 Prof. Stanley Hall gives, as an illustration, "the new psychology of crime and criminals, who are so shot through, body and soul, with atavisms that only the early history of the race can explain them." 
of Species," Sir Francis Galton has told us that his dominant feeling was one of freedom.

For one must remember that Darwin attacked a whole series of problems which, for most of his contemporaries, were either insoluble mysteries or a preserve for transcendental interpretation. "Evolution," Prof. Bateson says, " is a process of variation and heredity. The older writers, though they had some vague idea that it must be so, did not study variation and heredity. Darwin did, and so begat, not a theory, but a science." 1 He showed that the deeper mysteries of life were in a measure accessible to the scientific method. He won freedom for the application of the evolution formula to man as well as to other creatures, and not only to his body, but to his emotions and behaviour. $\mathrm{He}$ was one of the founders of genetic psychology, which, though still hardly above the ground, is destined to make for the growing freedom of the human spirit. We mean not merely intellectual freedom from obscurity, but a practical freedom as well; for in regard to the mind, as well as the body, Darwin set a-going a kind of inquiry into individual development and racial evolution, into variation and heredity, which promises to give us a firmer control of life. We are only beginning to realise that the truth which is in Darwinism shares with all truth the power of making us free.

Darwin gave men confidence in the interpretative value of the evolution formula, which makes the present less obscure by throwing on it the light of the past, and every one knows how the interpretation has been applied to mind,

1 "Darwin and Modern Science," (1909), p. 88. 
to morals, to language, to art, to customs, to religion. Even the evolution theory has had its evolution, and is still, happily, being evolved.

Of the wide diffusion of the evolutionary way of looking at things which Darwin justified, we give a single example, as a diagram as it were. After the disaster of Königgrätz the Austrian Parliament met to consider what steps should be taken for the re-consolidation of the monarchy, and a distinguished member of the Upper House began a famous speech with the words, "The first thing we have to consider is: Is Charles Darwin right, or is he not?"-" and upon the rightness of Darwin's theory it was gravely proposed to reconstruct the Austrian monarchy." 1

Darwin once expressed satisfaction that he had not been permitted to become a "specialist"; it is hardly too much to say that there is no specialism in natural science which he has left unaffected by his influence.

(VIII) Ideal of Scientific Mood and Method. -What do we owe to Darwin? An ideal of the scientific mood and of scientific workmanship. As it will be a long time before Science weeps, like Alexander, having no more worlds to conquer, perhaps this ideal is not the least of Darwin's legacies. If we can follow Darwin in the spirit, not necessarily in the letter, we shall not go far astray. As Prof. T. H. Morgan finely says : "It is the spirit of Darwinism, not its formulæ, that we proclaim as our best heritage." For this reason, and because the scientific spirit is a big fact in modern life, let us consider the features

1 See Sir Archibald Geikie's Speech at the Darwin-Wallace Celebration, Linnean Society (July 1st, 1908), p. 53. 
of the scientific mood, and Darwin's illustration of them.

In his stimulating presidential address at the meeting of the British Association at Dover in 1899, Sir Michael Foster discussed the distinctive features of the scientific spirit-of which he was himself a fine embodiment. His answer was that the features of the fruitful scientific mood are in the main three-truthfulness, alertness, and courage. (1) "The seeker after truth must himself be truthful-truthful with the truthfulness of nature." (2) "He must be alert of mind, ever on the watch, ready at once to lay hold of Nature's hint, however small; to listen to her whisper, however low." (3) "Scientific inquiry has need of the moral quality of courage-not so much the courage which helps a man to face a sudden difficulty, as the courage of steadfast endurance." To the objection that truthfulness, alertness, and courage are virtues belonging to almost every one who has commanded or deserved success, Sir Michael answered: "That is exactly what I would desire to insist, that men of science have no peculiar virtues, no special powers. They are ordinary men, their characters are common, even commonplace. Science, as Huxley said, is organised common sense, and men of science are common men, drilled in the ways of common sense."

Characteristics of Scientific Mood : Passion and Reverence for Facts. - But let us consider the scientifio mood more analytically. The first characteristic of the scientific mood is $a$ passion and reverence for facts. Long ago Bacon said: "We should accustom ourselves to things themselves"; and to distinguish between appearance 
and reality is part of the unending business of science. Faraday said that the scientific investigator should be "not a respecter of persons, but of things." It was Huxley who spoke of "that enthusiasm for truth, that fanaticism of veracity, which is a greater possession than much learning; a nobler gift than the power of increasing knowledge." Darwin was a fine illustration of this passion for facts ; there have been few naturalists more careful as to data. He began collecting facts in regard to the work of earthworms when a young student in Edinburgh, and he published his fascinating book the year in which he died. His gardener said: "He moons about in the garden, and I have seen him stand doing nothing before a flower ten minutes at a time."

Scientific Caution.-Following from the passion of facts is a second characteristic of the scientific mood, namely, cautiousness, or distrust of finality and dogmatism of statement. Prof. W. K. Brooks says, in his "Foundations of Zoology": "The hardest of intellectual virtues is philosophic doubt, and the mental vice to which we are most prone is our tendency to believe that lack of evidence for an opinion is a reason for believing something else. ... Suspended judgment is the greatest triumph of intellectual discipline." As Huxley said: "The assertion that outstrips the evidence is not only a blunder but a crime." As Karl Pearson says: "The scientific man has, above all things, to strive at self-elimination in his judgments, to provide an argument which is as true for each individual mind as for his own." What a fine temper there is in Darwin's statement-" I have steadily endeavoured to 
keep my mind free so as to give up any hypothesis, however much beloved-and I cannot resist forming one on every subject-as soon as facts are shown to be opposed to it." "I had," he says, " during many years followed a golden rule, namely, that whenever a published fact, a new observation or thought came across me, which was opposed to my general results, to make a memorandum of it without fail, and at once; for I had found, by experience, that such facts and thoughts were far more apt to escapefrom the memory than favourable ones." Let us remember how Darwin opened his first note-book in 1837, conceived the idea of natural selection in 1838, sent a sketch of the theory to Hooker in 1844, read his joint-paper with Wallace in 1858, and published "The Origin of Species" in 1859. These dates are eloquent. It is interesting to notice that Wallace wrote his sketch in a week - the thought-stream of his fevered brain in spate.

Clearness of Vision.-A third characteristic of the scientific mood is dislike of obscurities, of blurred vision, of fogginess. Ignorance in itself is no particular reproach, if it is not carried too far, but it is essential to know when we know and when we do not. The mole has a strange half-finished lens, which is physically incapable of throwing a precise image on the retina. If there is any image, it must be a blurred tangle of lines. In our busy lives we tend to acquire mole-like lenses in regard to particular orders of facts; we see certain things clearly, others are blurs; but the scientific mood is in continual protest against obscurities, insisting upon lucidity. One of Bacon's most historically true aphorisms declares "Truth to emerge sooner from error 
than from confusion." Now we may claim for Darwin the quality of definiteness and lucidity. $\mathrm{He}$ was convinced of the efficacy of natural selection, and his exposition, though rarely elegant, is always clear. He did not understand how variations in the direction of fitness arose, and he said so. His yea was yea, and his nay, nay.

SENSE OF INTERRELATIONS.-A fourth characteristic of the scientific mood is a sense of the interrelations of things. The realisation of Nature as a great interconnected system is, indeed, one of the ends of science; to be on the outlook for interrelations is diagnostic of the scientific mood. We have seen how Darwin had the vision of the web of life with pre-eminent vividness.

Darwin's Method of Working.-As to Darwin's method of working, he tells us himself three things : (1) that he had from his earliest youth a desire to explain things, and that he could not resist forming an hypothesis on every subject; (2) that he accumulated large collections of facts and tried to formulate them in a general law; and (3) that he sought to anticipate all possible objections to his conclusion. In short, he was a deductive-inductive philosopher.

In speaking of Darwin's services, Romanes said: "A true scientific judgment consists in giving a free rein to speculation on the one hand, while holding ready the brake of verification with the other. Now it is just because Darwin did both these things with so admirable a judgment that he gave to the world of natural history so good a lesson as to the most effective way of driving the chariot of science." 1

1 “Darwin and After Darwin" (1897), vol. i. p. 7. 
Prof. Karl Pearson says, in his "Grammar of Science," that the scientific method is marked by the following features: " $(a)$ careful and accurate classification of facts and observation of their correlation and sequence; (b) the discovery of scientific laws by aid of the creative imagination; and $(c)$ self-criticism and the final touchstone of equal validity for all normally constituted minds." The writer had Darwin as well as Newton in mind when he framed this useful definition.

DARwIN ON HIS OwN SUCcess.--No one who has read Darwin's "Autobiography" can forget how he himself deals with the question of his success. "My success as a man of science, whatever this may have amounted to, has been determined, as far as I can judge, by complex and diversified mental qualities and conditions. Of these, the most important have been-the love of science, unbounded patience in long reflecting over any subject, industry in observing and collecting facts, and a fair share of invention as well as of common sense. With such moderate abilities as I possess, it is truly surprising that I should have influenced to a considerable extent the belief of scientific men on some important points."

Darwin's ACHIEVEMENTS.-Let us turn from that humility of greatness once more to the actual achievement. The idea of organic evolution, older than Aristotle, slowly developed from the stage of suggestion to the stage of verification, and the first convincing verification was Darwin's; from being an a priori anticipation it has become a detailed interpretation of nature, and Darwin is still the chief interpreter; from being a modal interpretation of the manner in which living 
creatures have come to be, it has advanced to the rank of a causal theory, the most convincing part of which men will never cease to call Darwinism.

In referring to Darwin's services, Huxley wrote : "Whatever be the ultimate verdict of posterity upon this or that opinion which Mr. Darwin propounded; whatever adumbrations or anticipations of his doctrines may be found in the writings of his predecessors; the broad fact remains that, since the publication, and by reason of the publication, of 'The Origin of Species' the fundamental conceptions and the aims of students of living nature have been completely changed. . . B But the impulse thus given to scientific thought rapidly spread beyond the ordinarily recognised limits of biology. Psychology, ethics, cosmology were stirred to their foundations, and 'The Origin of Species' proved itself the fixed point which the general doctrine needed in order to move the world."

Co-operating INFLUENCES. - To understand how all this came about we must get beyond the personality of Darwin. We must shake ourselves free from all creationist appreciations of Darwin and Darwinism; we must recognise the services of pioneers who helped to make the time ripenotably, for instance, Robert Chambers, whose work has seldom been adequately appreciated; we must inquire into the acceptance of evolutionary conceptions in regard to other than biological orders of facts; we must realise how the growing success of scientific interpretation along other lines gave confidence to those who refused to admit that there was any domain from which science could be excluded as a trespasser; we 
must take account of the development of philosophical thought-for instance in Herder, Kant, and Hegel ; we should also, if we are wise enough, consider social changes. In short, we must abandon the idea that we can understand a great step like the acceptance of the evolutionist outlook without getting beyond the individual prophet, without associating his work with contemporary evolution in other departments of activity. The man and the moment must agree, and, as Professor R. M. Wenley says in this very connection, " genius rarely achieves supremacy without the co-operant ' social mind.'

There is a risk of attaching too much importance to the force of individual effort on the one hand, and to the ripening of public opinion on the other. The storm of opposition roused by the publication of "The Origin of Species" shows how far the time was from being ripe. To say, as Samuel Butler said, "Buffon planted, Erasmus Darwin and Lamarck watered, but it was Mr. Darwin who said 'That fruit is ripe' and shook it into his lap," seems to us as wilful a perversion of historical fact as that other statement by the same ingenious and often well-advised critic, " Darwin was heir to a discredited truth, and left behind him an accredited fallacy." Much more accurate is Huxley's fine pronouncement ${ }^{1}$ : "None have fought better, and none have been more fortunate, than Charles Darwin. He found a great truth trodden underfoot, reviled by bigots, and ridiculed by all the world; he lived long enough to see it, chiefly by his own efforts, irrefragably established in science." That the time was far from ripe is shown by Darwin's foreboding:

1 “Darwiniana," p. 247. 
"When my notes are published I shall fall infinitely low in the opinion of all sound naturalists; so this is my prospect for the future." That the time was far from ripe is well shown in a passage in the second volume of Buckle's " History of Civilisation," which was published two years after "The Origin of Species ": "We are in that predicament that our facts have outstripped our knowledge, and are now encumbering its march. The publications of our scientific institutions, and of our scientific authors, overflow with minute and countless details, which perplex the judgment, and which no memory can retain. In vain do we demand that they should be generalised and reduced into order. Instead of that, the heap continues to swell. We want ideas, and we get more facts. We hear constantly of what nature is doing, but we rarely hear of what man is thinking. Owing to the indefatigable industry of this and the preceding century, we are in possession of a huge and incoherent mass of observations, which have been stored up with great care, but which, until they are connected by some presiding idea, will be utterly useless." And yet one of the greatest of generalisations, one of the most powerful of presiding ideas, was awaiting Buckle's recognition. It was eminently characteristic of Darwin that the accumulation of facts was to him not an end but a means to an end.

Particular Reasons for Darwin's Success.We must grant that the intellectual temper of the time was changing, that in various departments men were becoming familiar with the historical method-the first step to becoming evolutionists, that the genetic view of nature was insinuating 
itself like a slow incoming tide in men's minds, and that the scientific spirit had ripened since the days when Cuvier laughed Lamarck out of court, but we must still ask, more personally, how it was that Darwin succeeded so well. There are several answers.

Because, in the first place, he had clear visionspensées de la jeunesse, exécutées par l'âge mûrwhich a University curriculum had not made impossible, which the Beagle voyage-a Columbus voyage that discovered a new world-had made vivid, which an unrivalled British doggedness made real-visions of the web of life, of the fountain of change within the organism, of the struggle for existence, of discriminate winnowing or selection, and of the spreading genealogical tree.

Because, in the second place, he put so much grit into the verification of his visions, forcing them to the proof in an argument which is, of its kind-direct demonstration being out of the question-quite unequalled.

Because, in the third place, he broke down the opposition which the most scientific had felt to the seductive modal formula of evolution, by bringing forward a more plausible theory of the process than had been previously suggested. Nor can one forget, since questions of this magnitude are human and not merely academic, that Darwin wrote, of his condescension, so that all men could understand.

As Mr. Arthur Balfour recently said: "Charles Darwin's performances have now become part of the common intellectual inheritance of every man of education, wherever he lives or whatever his occupation or trade in life. To him we trace, 
in the main, the view which has affected, not merely our ideas of the development of living organisms, but our ideas upon politics, upon sociology, ideas which cover the whole domain of human terrestrial activity. $\mathrm{He}$ is the fount and origin, and he will stand for all time as the man who has made this great, and, as I think, beneficent revolution in the mode in which educated men can see the history, not merely of their own institutions, not merely of their own race, but of everything which has that unexplained attribute of life, everything that lives on the surface of the globe or within the depths of the ocean."

In any case, we must agree with what Huxley says of Darwin: "It is only by pursuing his method, by that wonderful single-mindedness, devotion to truth, readiness to sacrifice all things for the advance of definite knowledge, that we can hope to come any nearer than we are at present to the truths which he struggled to attain."

Darwin was no metaphysician; he always kept very close to earth-which is half the secret of the persistent strength of his teaching. For this reason, most appropriately, Prof. R. M. Wenley ended a very suggestive address ${ }^{2}$ on Darwin by quoting, in reference to Darwin's services, the fine words of a Scottish poet:

Man's thought is like Antæus, and must be Touched to the ground of Nature to regain Fresh force, new impulse, else it would remain Dead in the grip of strong Authority.

- Popular Science Monthly (1909), vol. Ixxiv. p. 395. 
But, once thereon reset, 'tis like a tree, Sap-swollen in spring-time: bonds may not restrain; Nor weight repress; its rootlets rend in twain Dead stones and walls and rocks resistlessly.

Thine, then, it was to touch dead thoughts to earth, Till of old dreams sprang new philosophies, From visions systems, and beneath thy spell Swiftly uprose, like magic palaces,Thyself half-conscious only of thy worthCalm priest of a tremendous oracle! 
CHAPTER II

\section{THE WEB OF LIFE}





\section{CHAPTER II}

\section{THE WEB OF LIFE}

Correlation of Organisms as well as Correlation of Organs-What the Metaphor of "The Web of Life" suggests-Dependence of Living Creatures upon their Surroundings-Nutritive Chains -Nexus between Mud and Clear Thinking-Correlation between Catches of Mackerel and Amount of Spring Sunshine -Nutritive Chains in the Deep Sea-Dependence of one Organism on another for the Continuance of the Species -Darwin's Instance of the Connection between Cats and Clover-Scattering of Seeds-Interrelations between Freshwater Mussels and Fishes-Life-histories of Parasites-Farreaching Influence of Certain Animals: Earthworms-Termites, or White Ant3-The Hand of Life upon the Earth-Practical Importance of a Realisation of the Web of Life.

Naturalists, in the true sense, who study the life of living creatures in nature, have always been distinguished by a keen perception of the inter-relations of things. Whether we take Gilbert White as representing the old school, or W. H. Hudson as representing the new, we get from their observations the same impression of nature as a vibrating system, most surely and subtly inter-connected. But it seems just to say that no naturalist, before or since, has come near Darwin in his realisation of the web of life, in his clear vision and picture of the vast system of linkages that penetrates throughout the animate world.

Correlation of Organisms as well as CorReLATION OF ORGANS.-In thinking of a living body we are accustomed to the idea of the correlation of 
organs. It is of the very nature of an organism that there should be mutual dependence among its parts. The organs are all partners in the business of life, and if one member changes others also are affected. This is especially true of certain organs that have developed and evolved together, and are knit by close physiological bonds. We know in health how nerve and muscle, brain and sense-organs, heart and lungs, are closely bound together in the bundle of life. We know in disease that a change in one organ often affects another, and the fact remains, though the nexus is sometimes mysterious. The state of our liver may give colour to our whole intellectual firmament, and a slight ocular derangement may warp a wise man's philosophy. The far-reaching importance of a little organ like the thyroid gland beside the larynx is well known; our intellectual as well as our bodily health depends on its soundness. Now, just as there is a correlation of organs within the body, so there is a correlation of organisms in that system of things which we call Nature. In both cases we are here using the word "correlation" in its deeper sense-that the various parts are more than mutually dependent, that they are in some measure co-ordinated, making larger systems workable.

What the Metaphor of "The Web of Life" sUGGESTS.-We may use the metaphor "web of life" in two ways. On the one hand, Nature has a woven pattern which science seeks to read, each science following the threads of a particular colour. There is a warp and woof in this web, which to the zoologist usually appear as " hunger " and "love." There is a changing pattern in the web, becoming more complex as the ages pass; and this is evo- 
lution. But the essential idea of a web is that of interlinking and ramifying. We can never tell where a thread will lead to. If one be pulled out, many are loosened. This is true of Nature through and through.

The phrase "web of life" suggests another picture-the web of a spider-often an intricate system, with part delicately bound to part, so that the whole system is made one. "The quivering fly entangled in a corner betrays itself throughout the web; often it is felt rather than seen by the lurking spinner. So in the substantial fabric of the world part is bound to part. In wind and weather, or in the business of our life, we are daily made aware of results whose first conditions are very remote; and chains of influence, not difficult to demonstrate, link man to beast, and flower to insect. The more we know of our surroundings the more we realise that nature is a vast system of linkages, that isolation is impossible." 1

Dependence of Living Creatures on their Surroundings.-We do not know what life in principle is, but we may describe living as action and reaction between organisms and their environment. This is the fundamental relationthe dependence of living creatures on appropriate surroundings, and the primary illustrations of linkages must be found here. The living creatures are real, just in the same sense as the surroundings are real; but it is plain that we cannot abstract the living creatures from their surroundings. When we try to do this they die-even in our thought of them, and our biology is only necrology.

1 "The Study of Animal Life," by J. Arthur Thomson (1890). 
Huxley compared a living creature to a whirlpool in a river; it is always changing, yet always apparently the same; matter and energy stream in and stream out; the whirlpool has an individuality and a certain unity, yet it is wholly dependent upon the surrounding currents. One may push the whirlpool metaphor too far, so as to give a false simplicity to the facts, for when vital whirlpools began to be there also emerged what cannot be discerned in crystal or dewdrop-the will to live, a capacity of persistent experience, and the power of giving rise to other lives. To ignore this is to attempt a falsely simple natural history. But what Huxley's metaphor of the whirlpool does vividly express is the dependence of living creatures on their surroundings. We cannot understand either the whirlpool or the trout apart from the stream.

When we think out this fundamental dependence upon surroundings, we see, for instance, that all our supplies of energy, all our powers of every kind - with our own hands, or by the use of animals, or by means of machinery-are traceable to the sun. Or again, it is easy to show that our society depends fundamentally not on gold, but on iron. We depend for food on plants and animals, and through these animals on plants ultimately; the plants feed upon air, water, and salts, which, with the aid of the energy of the sunlight, they build up into complex organic compounds; they cannot do this unless the sun shines through a screen of green pigment called chlorophyll; there cannot be chlorophyll without iron; therefore our whole social framework is founded on IRON.

Nutritive Chains.-Plants feed on their in- 
animate environment in a direct way that is impossible to animals, so we pass insensibly from dependence on surroundings to those nutritive chains which bind living creatures together in long series often quaintly suggestive of "The House that Jack Built" and similar old rhymes. We have ceased to wonder at the circulation of the blood in our body; have we begun to wonder enough at the ceaseless circulation of matter in the system of nature? As Heraclitus said, $\pi a ́ v \tau \alpha$ $\dot{\rho} \epsilon \dot{i}$, all things are in flux. "The rain falls; the springs are fed; the streams are filled and flow to the sea; the mist rises from the deep and the clouds are formed, which break again on the mountain-side. The plant captures air, water, and salts, and, with the sun's aid, builds them up by vital alchemy into the bread of life, incorporating this into itself. The animal eats the plant, and a new incarnation begins. All flesh is grass. The animal becomes part of another animal, and the reincarnation continues." 1 The silver cord of the bundle of life is loosed, and earth returns to earth. The microbes of decay break down the dead, and there is a return to air and water and salts. We may be sure that nothing real is ever lost; we are sure that all things flow. Penelope-like, Nature is continually unravelling her web and making a fresh start.

Nexus between Mud and Clear Thinking.To keep a famous inland fish-pond from giving out, some boxes of mud and manure were placed at the sides. Bacteria-the minions of all putrefaction-worked in the mud and manure, making

1 "The Bible of Nature," by J. Arthur Thomson (1908). (Scribner, New Xork. Clark, Edinburgh.) 
food for minute Infusorians, which multiply so rapidly that there may be a million from one in a week's time. A cataract of Infusorians overflowed from box to pond, and the water-fleas and other small fry gathered at the foot of the fall and multiplied exceedingly. Thus the fishes were fed, and, as fish-flesh is said to be good for the brain, we can trace a nexus from mud to clear thinking. What was in the mud became part of the Infusorian, which became part of the Crustacean, which became part of the fish, which became part of the man. And it is thus that the world goes round.

Correlation between Catches of Mackerel and Amount of Spring Sunlight.-A curious and most interesting correlation has been discovered by Dr. E. J. Allen between catches of mackerel and the amount of sunlight." The more sunshine in May, the more mackerel at Billingsgate. How does this work out? Mr. G. E. Bullen ${ }^{2}$ shows that "for the years 1903-1907 there appears to be a correlation between the number of mackerel taken during May and the amount of Copepod plankton, upon which the mackerel feed, taken in the neighbourhood of the mackerel fishing grounds during the same month." Mr. W. J. Dakin ${ }^{3}$ shows that the food of Copepods consists largely of the vegetable organisms of the plankton, such as diatoms, and of Infusorian-like organisms called Peridinidæ. But the production of this microscopic plankton, the "stock" of the "seasoup," depends partly on the composition of the

1 Journ. Marine Biol. Assoc. (1909), vol. viii. p. 394.

Ibid. p. 269.

Internat. Revue Hydrobiologie (1908), vol. i. 
sea-water, partly on the temperature, and partly on the amount of light available. There seems to be no correlation between the surface temperature and the abundance of mackerel, but Dr. Allen has shown a correspondence between sunshine and the catches. Thus we see that, if all flesh is grass, then in the same sense all fish is diatom.

Nutritive Chatns in the Deep Sea.-If we pass from the sunlit open sea to the floor of the deep sea-that strange, dark, cold, silent, plantless world-we find carnivorous animal preying upon carnivorous animal through long series-fish feeds on fish, fish on crustacean, crustacean on worm, worm on still smaller fry, and all ultimately depend on the basal food-supply-the ceaseless shower of moribund atomies sinking from the surface waters many miles, it may be, overhead, like the snowflakes on a quiet winter day.

Dependence OF ONE ORganism oN aNOTHER for the Continuance of the Species.-Passing from "nutritive chains," we may select a few illustrations of the dependence of one creature upon another for the continuance of its kind. The crowning instances are to be found in the interrelations between plants and animals which secure cross-fertilisation and the distribution of seeds. To both of these Darwin devoted much attention, and they were always favourite subjects with him.

Every one knows that flowering plants and flower-visiting insects have grown up throughout long ages together, in alternate influence and mutual perfecting. They are now fitted to one another as hand to glove. The insects visit the flowers for food; in so doing they carry the fer- 
tilising golden dust from blossom to blossom, so that the possible seeds become real seeds.

In 1793 a Berlin naturalist, Christian Konrad Sprengel, like Darwin in his perception of the web of life, published a pioneer book entitled "The Secret of Nature discovered in the Structure and Fertilisation of Flowers," in which he showed that most flowers have nectar which insects enjoy; that by the insects' visits pollination is secured; that there is no detail of the flower without its meaning-the colour is a flag to attract the insect's eye, conspicuous spots are honey-guides to the explorers, there are arrangements for keeping the pollen dry and for dusting it on the insects, and so on. If Sprengel had only discovered the utility of the cross-fertilisation, which Darwin proved experimentally, his work could hardly have been overlooked for nearly seventy years. In 1841 it came into Darwin's hands, and impressed him as being "full of truth," although "with some little nonsense." In Darwin's work Sprengel had his long-delayed reward.

Darwin's Instance of the Connection BEtween Cats aND Clover.-One of Darwin's instances of the web of life-given in connection with the pollination of flowers-has become familiar all over the world. It should never become trite to us and it should never be regarded as more than a particularly clear illustration of a general fact. "Plants and animals, remote in the scale of nature, are bound together by a web of complex relations. ... I have found, from experiments, that humble-bees are almost indispensable to the fertilisation of the heart's-ease (Viola tricolor), for other bees do not visit this 
flower. I have also found that the visits of bees are necessary for the fertilisation of some kinds of clover-thus, 100 heads of red clover (Trifolium pratense) produced 27,000 seeds, but the same number of protected heads produced not a single seed. Humble-bees alone visit red clover, as other bees cannot reach the nectar. . . . Hence we may infer as highly probable that, if the whole genus of humble-bees became extinct or very rare in England, the heart's-ease and red clover would become very rare, or wholly disappear." We know that the red clover imported to New Zealand did not bear fertile seeds until humblebees were also imported. " The number of humblebees in any district depends in a great measure on the number of field-mice, which destroy their combs and nests; and Colonel Newman, who has long attended to the habits of humble-bees, believes that more than two-thirds of them are thus destroyed all over England." Now the number of mice is largely dependent, as every one knows, on the number of cats; and Colonel Newman says: "Near villages and small towns I have found the nests of humble-bees more numerous than elsewhere, which I attribute to the number of cats that destroy the mice." Thus we may say, with Darwin, that next year's crop of purple clover is influenced by the number of humble-bees in the district, which varies with the number of field-mice; that is to say, with the abundance of cats!

Scattering of Seeds.-It is a fascinating chapter of natural history which tells us how cross-pollination is effected-here by a bee and there by a butterfly, occasionally by a long-billed 
humming-bird beautifully poised before the flower with almost invisibly rapid vibrations of its wings, and occasionally by a slowly moving snail of epicure appetite. But not less important is the part played by animals in the scattering of seeds, and here again Darwin gives us the classic case of fourscore seeds germinating out of a ball of mud from a bird's foot. From one instance you may learn all, and see that much of Darwin's work has been an eloquent commentary on that memorable saying about the sparrow that falls to the ground. Such a simple event literally sends a throb through surrounding nature; we can follow its effects a few steps, just as we follow for a few yards the ripples made when we throw a stone into a still lake: in neither case can we doubt that the spreading influences are real, though they pass beyond our ken.

INTERRELATIONS BETWEen Fresh-WATER MusSELS AND FISHES.-As a striking illustration of the inter-linking of different forms of life, we may take the case of the fresh-water mussels and their larvæ. The fertilised eggs develop in the outer gill-plate of the mother-mussel, and minute bivalve larvæ, called Glochidia, are formed. The mussel keeps these within the cradle until a freshwater fish-such as the minnow-comes into the vicinity, and then she sets them free. In a way that we do not understand, the simple constitution of the larvæ is tuned to respond to the presence of minnows and the like, and with snapping valves they manage to fix themselves to their host. After a short period of temporary parasitism, at the end of which there is a metamorphosis, they drop off from the fisb into the mud, often far 
from their birth-place. This is curious enough, but the idea of linkages becomes incandescent in the mind when we note that, just as the fresh-water mussel has young temporarily parasitic on fishes, so a fresh-water fish, the bitterling (Rhodeus amarus), has its young temporarily parasitic in the gills of the mussel.

Life-histories of Parasttes. - When we pass to parasites in a stricter sense we find the most extraordinary interconnections, the most widely separated animals often sharing a parasite between them. Liver-rot, which has repeatedly killed a million sheep in a year in Britain alone, is due to a parasite which passes from sheep to water, from water to water-snail, from water-snail to grass, from grass to sheep. The tapeworm of the cat has its bladder-worm stage in the mouse, the sturdie-worm of the sheep's brain has its tapeworm stage in the dog, and similar relations hold for hundreds of species. The troublesome threadworm of human blood (Filaria sanguinis hominis) is transferred from man to man by the mosquito, and the guinea-worm, which was probably the fiery serpent that vexed the Israelites in the desert, which passes into man in drinking-water, spends its youth in a minute water-flea, called by the giant's name of Cyclops. The importance of tse-tse flies in transmitting the minute animals which cause sleeping-sickness and allied diseases is known to all. We have spoken of the connection between cats and clover, and there is a not less striking connection between cats and plague. For it seems to have been shown in India that the more cats the fewer rats, and the fewer rats the fewer rat-fleas, which 
are the agents in passing the plague-germs to man.

Far-Reaching Influence of Certatn Animals : Earthworms.-We realise the idea of the web of life in another way when we consider the far-reaching influence of particular kinds of activity, the best instance being the work of earthworms. In 1777 Gilbert White got at the very root of the matter. "The most insignificant insects and reptiles are of much more consequence and have much more influence in the economy of nature than the incurious are aware of. . . . Earthworms, though in appearance a small and despicable link in the chain of nature, yet, if lost, would make a lamentable chasm. ... Worms seem to be the great promoters of vegetation, which would proceed but lamely without them, by boring, perforating, and loosening the soil, and rendering it pervious to rains and the fibres of plants; by drawing straws and stalks of leaves and twigs into it; and, most of all, by throwing up such infinite numbers of lumps of earth called worm-casts, which, being their excrement, is a fine manure for grain and grass. Worms probably provide new soil for hills and slopes where the rain washes the earth away; and they affect slopes probably to avoid being flooded. ... The earth without worms would soon become cold, hard-bound, and void of fermentation, and consequently sterile.... These hints we think proper to throw out, in order to set the inquisitive and discerning at work. A good monograph of worms would afford much entertainment and information at the same time, and would open a large and new field in natural history." 
The monograph that Gilbert White wished for in 1777 was published by Darwin in 1881, the year before he died-" the completion," he said, " of a short paper read before the Geological Society more than forty years ago." With his characteristic thoroughness and patience he worked out the part that earthworms have played in the history of the earth, and proved that they deserve to be called the most useful animals. By their burrowing they loosen the earth, making way for the plant rootlets and the raindrops; by bruising the soil in their gizzards, they reduce the particles to more useful, powdery form; by burying the surface with castings brought up from beneath, they have been for untold ages ploughers before the plough, and by burying leaves they have made a great part of the vegetable mould over the whole earth. In illustration of the last point, we may notice that we recently found thirteen midribs of the leaves of the rowan, or mountainash, radiating round one hole like the spokes of a wheel; the withering leaflets had been carried down, and two were sticking up at the mouth of the burrow: that meant 91 leaflets to one hole. Darwin showed that there often are 50,000 (and there may be 500,000 ) earthworms in an acre; that they often pass ten tons of soil per acre per annum through their bodies; and that they often cover the surface at the rate of three inches in fifteen years. Though our British worms only pass out about $20 \mathrm{oz}$. of earth in a year, the weights thrown up in a year on two separate square yards which Darwin watched were respectively 6.75 $\mathrm{lb}$. and $8.387 \mathrm{lb}$., which correspond to $14 \frac{1}{2}$ and 18 tons per acre per annum. 
We follow the work further and it becomes evident that the constant exposure of the soil bacteria on the surface is bound to be important, on the one hand, in allowing them to be scattered by wind and rain, on the other in exposing them to the beneficent action of the sunlightwhich is the most universal, effective, and economical of all germicides.

In Yorubaland, on the West Coast of Africa, Mr. Alvan Millson calculated that about 62,233 tons of subsoil are brought every year to the surface of each square mile, and that every particle of earth, to the depth of two feet, is brought to the surface once in twenty-seven years. It need hardly be added that the district is fertile and healthy.

Earthworms play their part in the disintegration of rocks, letting the solvent humus-acids of the soil down to the buried surface. Their castings on the hill-slopes are carried down by wind and rain and go to swell the alluvium of the distant valleys or the wasted treasures of the sea. The well-known parallel ledges along the slopes of grass-clad hills are partly due to earthworm castings caught on sheep-tracks, and thus we begin to connect the earthworms not only with our wheat-supply but with our scenery. Well may we say, with Darwin : "It may be doubted whether there are many other animals which have played so important a part in the history of the world as have these lowly organised creatures." Those who wish to understand Darwinism should always begin with Darwin's last book-“"The Formation of Vegetable Mould through the Action of Worms" (1881). It illustrates the web of life, 
the idea of which is essential to an understanding of the struggle for existence and natural selection. But it also illustrates what Darwin had learned from Lyell-that great results may be brought about by the accumulation of infinitesimal items. As Prof. A. Milnes Marshall said: "The lesson to be derived from Darwin's life and work cannot be better expressed than as the cumulative importance of infinitely little things."

Termites, or White ANTs.-Henry Drummond, in his "Tropical Africa," tried to make out a case for the agricultural importance of termites, or white ants. It is well known that these oldfashioned insects have a pruning action in the forest, destroying dead wood with great rapidity. Houses and furniture, fences and boxes, as well as forest-trees, fall under their jaws. In some places, " if a man lay down to sleep with a wooden leg, it would be a heap of sawdust in the morning." But what of the termites' agricultural importance? The point is that they keep the soil circulating by constructing earthen tunnels up the sides of trees and posts and by making huge obelisk-like ant-hills, or termitaries. "The earth-tubes crumble to dust, which is scattered by the wind; the rains lash the forests and soils with fury, and wash off the loosened grains to swell the alluvium of a distant valley." It must be noted, however, that Drummond did not prove his case with sufficient precision, and there is, as Escherich points out in his beautiful study of termites, ${ }^{1}$ this difficulty, that, while the castings of earthworms are soft and loose, the earth-tubes and constructions of termites are stony.

1 “Die Termiten." (Leipzig, 1909.) 
Escherich does, however, admit that the termites have some agricultural importance, and he points out that there are other services to be put to the credit side of their account. They prune off wood that has begun to go ; they destroy rotting things, including the bodies of small animals; they make for cleanliness and health. In some low-lying tracts, as Silvestri has shown, there are dry stretches, "termite islands," which have been gradually built up from the broken-down remains of termitaries. Nor should it be forgotten that the white ants are often used as food. On the other hand, Escherich does not hesitate to rank them as among the great hindrances to the spread of civilisation. They insidiously devour everything wooden, from the telegraph-post to the wooden butt of the gun hanging against the wall, from books in the library to corks in the cellar. There does not seem sufficiently precise information in regard to the living plants that they attack, and no safe general statement can be made except that their appetite is large and catholic.

With a centre in earthworms, what a variety of interests must be included within the radius of their life and work!-centipedes, birds, moles, seedlings, man. The same is true of termites, and two further illustrations may be given. $\mathrm{Ob}$ servers have reported about thirty different species of termites with the habit of feeding on fungi grown within the termitary on specially constructed mazy beds. The habit is interesting in many ways ; for instance, because the fungi afford a supply of nitrogenous material which is scarce in the ordinary diet of wood, and also because a similar habit 
occurs in the quite unrelated true ants. Finally, the web is illustrated by the numerous boarders, mostly beetles, that are found in the termitariesnot hostile intruders or parasites, but guests which are fed and cared for apparently for the sake of a palatable exudation with a pleasant, narcotising effect on the termites. With a centre in termites, what a variety of interests must we not include within the radius of their life and work!-fungi and trees, beetles and birds, lizards and ant-eaters, and man more than any.

The Hand of Life upon the Earth.-The hand of life has been working upon the earth for untold ages. Take plants, for instance. The seaweeds lessen the force of the waves, the lichens eat into the rocks, the mosses form huge sponges on the moors which keep the streams flowing in days of drought. Many little plants are for ever smoothing away the wrinkles on the earth'stheir mother's-face, and they adorn her with jewels. Others that have formed coal have enriched her with ages of entrapped sunlight. The grass-which began to appear in Tertiary agesprotects the earth like a garment; the forests affect rainfall and temper climate, besides sheltering multitudes of living things, to many of whom every blow of the axe is a death-knell. No plant, from bacterium to oak-tree, lives or dies to itself, or is without its influence upon the earth. So among animals there are destructive borers and burrowers and conservative agents, such as the coral-polyps and the chalk-forming Foraminifera.

Practical Importance of a Realisation of THE WeB of LIFE.-What has Darwinism to do with human life? The answer at this stage in 
our inquiry is clear: we must respect the web of life if we wish to master Nature. She must be humoured, not bullied. Emerson included in his vision of a perfected earth the absence of spiders, but the absence of spiders-which snare so many injurious insects-would mean the absence of much else, man probably included. In a northern county in Scotland the proprietors were justly annoyed at the injuries inflicted on young trees by squirrels, and they formed a squirrelclub, setting a price on the beautiful rodent's head. Perhaps a wiser course would have been to begin by inquiring what disturbance of the balance of nature had allowed the squirrels to multiply so disastrously. But, after a period of squirrelslaughter and some jubilation thereat, a cloud began to rise in the sky. The wood-pigeons were multiplying worse than ever, and the farmers, at least, said with no uncertain voice that they preferred the squirrels. An imperfect recognition of the web of life had left out of account the notable fact that squirrels destroy large numbers of young wood-pigeons.

One of the hopeful symptoms of the last few years is the reawakening of an interest in woods and forests. Every one knows how terribly these have been wasted, and how the disastrous results have affected rainfall and irrigation, climate and crops, and even the character of the people. Here what was once a pleasant stream is now like a gravelly road, and there the fertile plains are flooded; here the wind is sweeping away the soil, and there both beauty and health have departed. The birds which the woods once sheltered are driven elsewhere, and the insect- 
pests are rife among the crops. For " the cheapest and most effective insecticides are birds."

The recognition of consequences-often farreaching-grows with us as we work with the idea of the web of life, as we see in proper perspective the criminality of those who are ruthless. President Roosevelt ${ }^{1}$ has declared his abomination of "the land-skinner"- "the individual whose idea of developing the country is to cut every stick of timber of it, and then leave a barren desert for the home-maker who comes in after him. That man is a curse, and not a blessing, to the country. The prop of the country must be the man who intends so to run his business that it will be profitable to his children after him." Every right-thinking man, and especially those who have grasped the idea of the web of life, will say with Roosevelt, "I am against the landskinner every time."

It may be said that man must exterminate a good deal if he is to go on peaceably with his business, and it will be admitted that there has never been a strong enthusiasm, humanitarian or otherwise, against the elimination of rattlesnakes, and such like. The naturalist's answer is that every crusade should be carefully considered on its own merits, and that every careless and hasty destruction of life is to be condemned. Even in regard to snakes killing may be carried too far. Some creatures are, as it were, on the fringes of the web, while others occupy a position where many threads meet. It is scientifically and æsthetically deplorable that birds like the great auk and

1 Quoted by A. H. 3. Lucas in his admirable Presidential Address, "Proc. Linnean Soc. N.S.W." (1908), vol. xxxiii. pp. 1-38. 
mammals like the quagga should have been exterminated, but it is practically much more deplorable that we have lost so many hawks and weasels and other members of that pertinacious army whose guerilla warfare keeps hundreds of more humdrum creatures up to the scratch, and keeps "vermin" from becoming a plague. Moreover, it is extremely difficult to tell what may be the consequences of exterminating any creatureremote as it may seem from the beaten track of human affairs. One of the obvious lessons of Darwinism is that we should be slow to call any change unimportant. Everything counts, or may count. A so-called unimportant animal is destroyed and no immediate ill effects are seen. But who can tell ?

Very pertinent, for instance, is the question : What about the parasites that used to complete their life-history in romantic routine in this extinguished animal? Have we extinguished the parasite also? Or is it waiting, with a whip of scorpions, to chastise mankind for their ignorance of Darwinism?

The practical importance of recognising the web of life has been proved by the heavy penalties which man has often had to pay for disturbing the balance of nature, careless of results and ruthless of beauty, for not admitting that if we would master Nature we must first understand her. How much has Australia had to pay for the introduction of rabbits in 1860, or America for sparrows? Sometimes the introduction has been unconscious, and man has only to blame himself for letting the intruder take hold, as in the case of the Phylloxera in France, or of the 
Colorado Beetle in Ireland. "Ignorance of nature," Mr. A.H. S. Lucas says, " is costly. By disturbing the balance of nature, man has introduced foes into his own household." Speaking of Australia, he says : "How much is needed for the eradication of Bathurst Burr, Prickly Pear, Water-hyacinth, Bramble and Sweetbriar, Codlin Moth, Waxy Scale, Pear Slug, and Red Spider, owing to carelessness or lack of knowledge in early days ? " 1

An obvious moral is that we should be careful in our introductions of new organisms-man included-into new surroundings. The primary consequences may be predictable, but the secondary and the tertiary consequences-who is sufficient for these things? We have records of the unconscious introduction of rats into Jamaica, where they became a pest. To destroy them mongooses were imported, and the rats were soon checked. But the mongooses, having finished the rats, began to eat up the poultry and young birds of various kinds. As this went on the injurious insects and ticks, that the birds used to eat, began to gain the ascendant. A recent report-which requires confirmation-says that the increase of ticks is making life a burden to the mongooses. Thus a balance will be again arrived at. There is no doubt of that, but how much is often unnecessarily lost by the way!

1 "Presidential Address, Proc. Linnean Society N.S. Wales" (1908), vol. $x \times x$ iii. pp. 1-38. 



\section{CHAPTER III}

\section{THE STRUGGLE FOR EXISTENCE}





\section{CHAPTER III}

\section{THE STRUGGLE FOR EXISTENCE}

The Idea not so Simple as it seems-The Anthropomorphism of the Idea-Different Forms of the Struggle for ExistenceStruggle for Existence in the Plant World-Illustration of the Complexity of the Struggle for Existence-Reasons for the Struggle for Existence-Results of the Struggle for ExistenceBreadth of the Darwinian Concept of the Struggle for Existence-The other Side of the Struggle for ExistenceMutual Aid-Application of the Concept to Human Life.

The Idea not so Simple as IT seems.-No evolutionist phrase is more familiar than " the struggle for existence," which has passed into everyday usage. Yet it is not easy to grasp its full meaning, or to keep it vividly in mind. "Nothing is easier," Darwin said, "than to admit in words the truth of the universal struggle for life, or more difficultat least I have found it so-than constantly to bear this conclusion in mind. Yet, unless it be thoroughly engrained in the mind, the whole economy of nature, with every fact on distribution, rarity, abundance, extinction, and variation, will be dimly seen or quite misunderstood." 1

If a recognition of the "struggle for existence" is essential to a clear outlook on nature, and if Darwin found difficulty in bearing it constantly in mind, we must be prepared to take some pains in trying to get a grasp of the facts which the

$$
\text { I "The Origin of Species," p. } 49 .
$$


phrase sums up. This is the more desirable since there is often tyranny in a phrase, especially when it is misunderstood. Are we sure that we understand what the struggle for existence means? Are we clear that it means much more than the bare words suggest? Do we understand that the phrase is a biological formula which has at the same time the misfortune of being an anthropomorphic metaphor?

From ancient days there had been a recognition of a struggle in nature-we find the idea expressed by Aristotle and by Lucretius, and more definitely by several of the pioneers of modern evolution theory-but it was Darwin who first realised its length and breadth, its height and depth, and, what is more, its dynamic significance. ${ }^{1}$

The ANthropomorphism of the IDEA.-In trying to understand the past and present of living creatures naturalists have followed with some success two very different methods, which seem opposed to one another, but are rather complementary. The one method is to inquire into the material machinery of vital activity, to throw on the puzzling drama of life the light of chemistry and physics. This is a sound method as far as it goes. The celery is blanched because

1 It is interesting to notice how often Tennyson turns to certain aspects of the struggle for existence, as when he speaks of Nature "red in tooth and claw with ravine," "So careless of the single life," or in the well-known lines :

"For life is not as idle ore;

But iron dug from central gloom,

And heated hot with burning fears,

And dip't in baths of hissing tears,

And batter'd by the shocks of doom

To shape and use." 
it is hidden from the light; the child is pale because, roughly speaking, it has not enough of iron in its blood. The defect of the method is that, unless its partiality be borne in mind, it is apt to give a false simplicity to the facts, for it is quite certain that we cannot at present redescribe vital happenings in terms of modern physics and chemistry-vitalistic as these are. The old materialism has been found out.

The other method is to read man into the beasts and even into the flowers of the field, to interpret the life of animals and plants in terms of human life. This is also a sound method as far as it goes. Its defect is that, verification being difficult, we are apt to land in fanciful anthropomorphism. Perhaps we may say, without disrespect, that it was in great part Darwin's method, just as the other was Spencer's. Darwin approached the naturalist's problem from above, Spencer from below.

No better illustration of Darwin's wholesome anthropomorphism can be found than the cardinal idea of the struggle for existence. It is an idea borrowed from human life; it was consciously suggested to Darwin by reading Malthus; it was subconsciously suggested by the keen industrial competition, more striking-because more novelin Darwin's day than in ours. In human life the phrase "struggle for existence" is a formula summing up in three words half the misery and half the happiness of mankind. It means that when Nature has said to man "you must dio" he has always answered back "I will live." " It means that he has fought with wild beasts and ${ }^{1}$ See "The Kingdom of Man," by Sir E. Ray Lankester. 
worsted them or tamed them, that he has sifted out the wholesome from the poisonous plants, that cowering and crouching for ages, he has watched the forces of nature till he has mastered their secrets, that he has been to his fellows since the beginning the strangest mixture of self-assertiveness and sympathy, that he has kept up an age-long endeavour after well-being-always at his best when rowing hard against the stream.

The formula, "struggle for existence," familiar in human affairs, was used by Darwin in his interpretation of organic life, and he showed that we gain clearness in our outlook on animate nature if we recognise there, in continual process, a struggle for existence not merely analogous to, but fundamentally the same as that which goes on in human life. He projected on organic life a sociological idea, and showed that it fitted. But while he thus vindicated the relevancy and utility of the sociological idea within the biological realm, he declared explicitly that the phrase "struggle for existence" was meant to be a shorthand formula, ${ }^{1}$ summing up a vast variety of strife and endeavour, of thrust and parry, of action and reaction. The idea has been better realised by naturalists than by the severer laboratory specialists. "It was certainly no chance," Weismann says, "that the struggle for existence first revealed itself to men who had spent the greater part of their lives in the open air." Similarly, Prof. Poulton suggests that the main reason why Huxley never appreciated the theory

1 “For words are wise men's counters-they do but reckon by them; but they are the money of fools." Hobbes, "Leviathan," Pt. I. ch. iv. 
of natural selection was that he had so little of the naturalist's mood and experience.

DifFerent Forms OF THE STRUGGLE For Existence.-Some of Darwin's successors have taken pains to distinguish a great many different forms of the struggle for existence, and this kind of analysis is useful in keeping us aware of the complexities of the process. Darwin himself does not seem to have cared much for this logical mapping out and defining; it was enough for him to insist that the phrase was used "in a large and metaphorical sense," and to give full illustrations of its various modes. For our present purpose it is enough to follow his example.

(a) Struggle between Fellows.-When the locusts of a huge swarm have eaten up every green thing they sometimes turn on one another. This cannibalism among fellows of the same species-illustrated, for instance, among many fishes-is the most intense form of the struggle for existence. An eerie struggle occurs between sister embryos in the egg-capsules of the buckie and the dogwhelk on the sea-shore. This sort of thing has its close analogue in what goes on between thicksown seedlings of the same kind, which compete with one another for room and food and light. The struggle does not need to be direct to be real-the essential point is that the competitors seek after the same desiderata of which there is a limited supply. Whether an adult frog eats a tadpole of its own kind, or a female spider her suitor, or coral polyps compete for the same niche, or rabbits for the same scanty food, the formula is the same in all cases, and, apart from chance, the result will be the same-the survival 
of those fittest for the particular conditions. The struggle may be for food, or foothold, or breathing-space, or what is sought after may be a luxury, as is seen in the wild stampede of the reindeer when the longing to visit the salt seashore becomes irresistible-many are overthrown and trampled in the mad rush.

As an instance of keen struggle between nearly related species, Darwin referred to the combats of rats. The black rat was in possession of many European towns before the brown rat crossed the Volga in 1727; whenever the brown rat arrived the black rat had to go to the wall. Thus at the present day there are practically no black rats in Great Britain. Here the struggle for existence is again directly competitive. It is difficult to separate off the struggle for food and foothold from the struggle for mates, and it seems clearest to include here the battles of the stags and the capercailzies, or the extraordinary lek of the blackcock-showing off their beauty at sun-rise on the hills.

(b) Struggle between Foes.-In the locust swarm and in the rats' combats there is competition between fellows of the same or nearly related species, but the struggle for existence includes much wider antipathies. We see it between focs of entirely different nature, between carnivores and herbivores, between birds of prey and small mammals. In both these cases there may be a stand-up fight, for instance between wolf and stag, or between hawk and ermine; but neither the logic nor the biology of the process is different when all the fight is on one side. As the lemmings, which have over-populated the Scandinavian 
valleys, go on the march they are followed by birds and beasts of prey, which thin their ranks. Moreover, the competition between species need not be direct; it will come to the same result if both types seek after the same things. The victory will be with the more effective and the more prolific.

In the same way we pass from the struggle of similar seedlings in the over-crowded garden-plot to the struggle of coarser with finer grasses after a veldt-fire-in many cases apparently ending in the survival of the coarsest.

(c) Struggle with Fate.-Our sweep widens still further, and we pass beyond the idea of competition altogether, to cases where the struggle for existence is between the living organism and the inanimate conditions of its life-for instance, between birds and the winter's cold, between aquatic animals and changes in the water, between plants and drought, between plants and frost-in a wide sense, between Life and Fate. ${ }^{1}$

The Struggle for Existence in the Plant WORLD.-We may be saved from taking a narrow view of the struggle for existence if we emphasise the fact that the concept must apply to plants as much as to animals. "It has always pleased me," Darwin said, "to exalt plants in the scale of organised beings," and in his books "The Power of Movement in Plants," "Climbing

1 We cannot here pursue the suggestive idea that, besides struggle between individuals, there is struggle between groups of individuals - the latter most notably developed in mankind. Similarly, working in the other direction, there is struggle between parts or tissues in the body, between cells in the body, between equivalent germ-cells, and, perhaps, as Weismann pictures, between the various multiplicate items that make up our inheritance. 
Plants," and "Insectivorous Plants," we find most interesting evidence that they are not so sound asleep as is often thought. Among the insectivorous plants we find actively aggressive, almost militant, forms, like the well-known Venus Fly-trap and the Sundew. Do they struggle less really than the octopus? Has not the Venus Fly-trap more than a hint of memory? Yet how impossible to draw the line where aggressiveness ceases! We have to include the passive pitcher-plants and bladderworts. Apart from actually carnivorous plants there are various orchids that entrap, or, we may almost say, visibly resent certain intruding insects, and there are many common plants that have deep moats where unwelcome visitors drown, hedges of hairs where they are entangled, sticky surfaces where they are limed.

There is no bloodshed among plants, but there is over-crowding, crushing, starving, smothering, strangling. Whether we take two lichens-each a quaint partnership of Alga and Fungus-competing for room to grow on an exposed stone, or the plants in the meadow, or the weeds in the sluggard's garden, or the crowded life of the jungle, we find clear evidence of competition for space and light, for food and air. This has been beautifully expressed by R. L. Stevenson, in his poem "The Woodman":

Thick round me in the teeming mud

Brier and fern strove to the blood:

The hooked liana in his gin

Noosed his reluctant neighbours in :

There the green murderer throve and spread,

Upon his smothering victims fed, 
And wantoned on his climbing coil.

Contending roots fought for the soil

Like frightened demons: with despair

Competing branches pushed for air.

Green conqu ors from overhead

Bestrode the bodies of their dead :

The Cæsars of the sylvan field,

Unused to fail, foredoomed to yield:

For in the groins of branches, lo!

The cancers of the orchid grow.

Silent, as in the listed ring,

Two chartered wrestlers strain and cling;

Dumb as by yellow Hooghly's side

The suffocating captives died;

So hushed the woodland warfare goes

Unceasing; and the silent foes

Grapple and smother, strain and clasp

Without a cry, without a gasp.

Here also sound Thy fans, O God,

Here too Thy banners move abroad:

Forest and city, sea and shore,

And the whole earth, Thy threshing-floor !

The drums of war, the drums of peace,

Roll through our cities without cease,

And all the iron halls of life

Ring with the unremitting strife.

But as we continue our illustrations of struggle among plants we lose the competitive note altogether,-in cases like the desert plant withstanding exceptional drought, and the northern plant withstanding unusually keen frost. No one doubts that extremes of drought and cold, and the like, press upon the ceaseless endeavour of even vegetable life, and that the plants answer back. They do not take every assault lying down.

Illustration OF tHe COMPlexity OF THE StrugGle FOR ExISTENCE.-To convey a broad 
impression of the struggle for existence we cannot do better than refer to a graphic picture drawn by Mr. W. H. Hudson in his charming "Naturalist in La Plata." The summer of 1872-3 in La Plata was rich in sunshine and showers; there was great wealth of blossom; the humblebees were very abundant; and the season was also very favourable for mice which devoured the bees. "In autumn the earth so teemed with mice that one could scarcely walk anywhere without treading on them; while out of every hollow weed-stalk lying on the ground dozens could be shaken." They were so abundant that " the dogs subsisted almost exclusively on them; the fowls also, from incessantly pursuing and killing them, became quite rapacious in their manner ; whilst the sulphur tyrant-birds (Pitangus) and the Guira Cuckoos preyed on nothing but mice." The cats became wild hunters; "foxes, weasels, and opossums fared sumptuously; even for the common armadillo (Dasypus villosus) it was a season of affluence." Countless numbers of storks and of short-eared owls came to assist at the general feast. The owls were so numerous that any evening after sunset $\mathrm{Mr}$. Hudson could count forty or fifty hovering over the trees about his house. They became destructive to birds as well as mice, and although the naturalist shot many to try to reduce the havoc they were making among the ovenbirds, the gaps he made were so rapidly filled that he grew sick of the cruel war in which he had hopelessly joined. "A singular circumstance was that the owls began to breed in the middle of winter." "By August (1873) the owls had vanished, and they had, indeed, 
good cause for leaving. The winter had been one of continued drought; the dry grass and herbage of the preceding year had been consumed by the cattle and wild animals, or had turned to dust, and, with the disappearance of their food and cover, the mice had ceased to be." The cats sneaked back to the houses. "It was pitiful to see the little burrowing owls; for these birds, not having the powerful wings and prescient instincts of the vagrant Otus brachyotus, were compelled to face the poverty from which the others escaped." They became tame with hunger, and so reduced as scarcely to be able to fly.

Fine weather, ready cover, and plenty of food had allowed the mice to multiply beyond measure, but their enemies had likewise increased. As the herbage disappeared, multiplication of mice ceased, and the army of enemies cleared off the residue so thoroughly that "in spring it was hard to find a survivor, even in barns and houses."

This "wave of life" is one of the most instructive of biological pictures. It illustrates the web of life, and the variety of the struggle for existence. A physical change lets the stream of life overflow, and, as the flood gathers momentum, it widens the breach in its banks. One struggle causes another struggle. Flowers abound, bees abound, mice abound, cats and owls abound, and there is struggle amongst all. Diets are changed, habits are changed, numerical proportions are changed, and then the season changes and all is over. The mice are reduced to a minimum and the wave of life is lost in the sand.

"The fact," Mr. Hudson says, " that species tend to increase in a geometrical ratio makes 
these great and sudden changes frequent in many regions. of the earth; but it is not often they present themselves so vividly as in the foregoing instance, for here, scene after scene, is one of Nature's silent, passionless tragedies open before us, countless myriads of highly organised beings rising into existence only to perish almost immediately, scarcely a hard-pressed remnant remaining after the great reaction to continue the species."

Reasons for the Struggle for Existence.The reasons for the struggle for existence among animals and plants are fundamentally the same as those which lie behind our own human struggle and endeavour. "Why do the people thus strive and cry?" Goethe asked, and gave the answer, "They will have food, they will have children, and bring them up as well as they can." So it is with other living creatures-their twofold, never-ending business is to care for themselves and to care for others. It has been said that hunger and love solve the world's problems, and this is true if we take a wide enough view of these notable words.

(a) One reason for struggle is to be found in the tendency to over-population. The river of life is always tending to overflow its banks. Struggle is the safety-valve against the internal pressure of rapidly increasing population. Wallace quotes Kerner to the effect that a common British weed (Sisymbrium sophia) often has three-quarters of a million seeds; if all grew to maturity for only three years the whole of the land-surface of the globe would not hold them. An annual plant with only two seeds would be represented by 
$1,048,576$ in the twenty-first year. "A bacillus less than $\frac{1}{5000}$ th of an inch in length multiplies, under normal conditions, at a rate that would cause the offspring of a single individual to fill the ocean to the depth of a mile in five days" (H. E. Crampton). "The cholera bacillus can duplicate every twenty minutes, and might thus in one day become $5,000,000,000,000,000,000,000$, with the weight, according to the calculations of Cohn, of about 7,366 tons. In a few days, at this rate, there would be a mass of bacteria as big as the moon, huge enough to fill the whole ocean " (Saleeby).

The slowest breeder among mammals is the elephant; it is supposed to rear one young one every ten years, but, as it lives to more than a hundred, Darwin calculated that in 750 years each pair would, if all their offspring lived and bred, be the ancestor of nineteen millions. The lemmings in the Scandinavian valleys become periodically so numerous that they eat up every plant, and must march or starve. The bands become an army which devastates as it goes, till their problem is solved in the waves of the Baltic or the North Sea.

A cod has two million eggs, they say; if these all developed into cods there would soon be no more fishing. An oyster may have sixty million eggs, and the average American yield is sixteen millions. If all the progeny of one oyster survived and multiplied, its. great-great-grand-children would number sixty-six with thirty-three noughts after it, and the heap of shells would be eight times the size of the world.

Huxley calculated that if the descendants of a single green-fly all survived and multiplied they 
would, at the end of summer, weigh down the population of China.

The common house-fly lays eggs in batches of 120 to 150 at a time, and may lay five or six of these batches during its life-of about three weeks in very hot weather. At the end of summer, if all developed, and if there were six generations, the progeny of a single pair, pressed together into a solid mass, would occupy a space of something like a quarter of a million cubic feet, allowing 200,000 flies to a cubit foot. There is no real increase, hence the mortality must be prodigious.

The intensity of the struggle can be inferred from the rate of increase. If there is slow multiplication and yet no falling off in the number of adults, there is no keen struggle for existence. If there is rapid multiplication and yet no increase in the number of adults, there must be a keen struggle for existence. It is useful to think over the simple equation: the number produced minus the number eliminated equals the normal number of adults.

(b) Another reason follows from the pattern of the web of life-there are nutritive chains, one organism depending on another for its food-supply. Indeed, the struggle that strikes us most is that which follows from the obvious fact that many animals prefer to be carnivorous. There is a good deal of the conjugation of the verb "To eat" in life, and the objection to be eaten is as natural to some animals as the desire to eat is to others.

(c) A third reason for struggle is to be found in the irregular changefulness of the physical environment. Give an animal time, and it may become marvellously well adapted to its surround- 
ings, as hand to glove; but when the surroundings change the adaptation is gone. In some cases, indeed, the living creature is adapted to change with the changes of its surroundings : turning white in winter, for instance, like the mountain-hare and the ptarmigan. But when the outer world changes irregularly, then the shoe pinches. The living creature must accept defeat or struggle, and its struggle may bring it success until a constitutional variation in the right direction has time to establish itself.

(d) Another reason for struggle is often overlooked-namely, the self-assertiveness of the vigorous animal. The lusty creature tends to be a hustler. It elbows its way through the crowd, jostling its neighbours. Even the plant pushes and obstructs, ensnares and strangles, stings and kills.

Results of the Struggle for Existence.There are three chief results of the ubiquitous struggle for existence.

(A) In the first place, there may be a reduction in numbers which relieves the pressure of population without directly making for progress. Out of 533 larvæ of the large garden white butterfly collected by Prof. Poulton, 422 died from ichneumon grubs: four out of every five-a great mortality. But since there was no evidence that the survivors were saved by being the possessors of some peculiarity which those eliminated lacked, the thinning had no evolutionary importance. It was merely fortuitous or indiscriminate elimination.

(B) In the second place, it may be that the organism is driven, by the pressure of the struggle, to seek out a new habitat, to choose a more appro- 
priate environment, or, what comes to the same thing, to form a new habit. From the beginning, necessity has been the mother of invention. For animals, as for man, the exploration of new territory has been a constantly recurrent result of the struggle for existence, and one of the most important. The open-air naturalist is familiar with the way in which nearly related species fill slightly different corners in the same crowded area. It is interesting, also, to think of the gradual peopling of strange habitats, such as the abysses of the ocean, the dark caves, and under the ground; or how fishes come ashore, and mammals get into the air, and crabs go up the mountains.

(c) In the third place, there may be discriminate elimination of the less fit to the given conditions, and it is this result that has most evolutionary interest. The black rat's territory is invaded by the brown rat, and soon there is only brown rat. Probably Kropotkin is right in suggesting that this case is less simple than Darwin supposed, for the arrival of a second rat made man wake up, and the weaker species yielded first. But there is evidence enough to lead us to believe that the struggle between brown rat and black rat leads to the rapid extermination of the black. From this extreme case we find every possible gradation, till all we can say is that the less fit are slightly handicapped in the race of life. But if the slight handicapping tells at all-and tells consistentlyas regards length and vigour of life, or number and vigour of offspring, then it will serve as a selective agent.

It is very important to realise that the struggle for existence may select without rapidly killing off 
the less fit. If it mean that the less fit have a more difficult life and do not live so long, if it mean that they have smaller and less vigorous families, if it mean that the parents are harassed so that they cannot give the offspring the best available start, then it will, in the long run, work out to the same result as if the less fit had come to a rapid violent end. The advantageous character that the fit variant possesses may be of survival-value, although the absence of it does not mean the sudden death of the less fit.

The elimination of the less fit may have a conservative influence, without resulting in any progressive change. It may keep the race up to an established standard. But this is precisely the same kind of process as that which results in progressive adaptation, and should not be separated off. It need hardly be said that when we find a state of 'affairs where slackness is tolerated, it means a temporary resting on the oars. Among 434 toads taken from the same place, Prof. W. E. Kellicott found 5 per cent. with injuries and $3 \cdot 68$ per cent. with abnormalities, mostly disadvantageous. The conditions of life were peculiarly easy, there was abundant food, there were few enemies, there were readily available means of protection and concealment.

Breadth of the Darwinian Concept of the StRugGle FOR Existence.-There are many authorities who insist that what Darwin particularly and mainly meant was the struggle between organisms of the same kind. Thus Weismann ${ }^{1}$ writes: The "struggle for existence," which

1 "Darwin and Modern Science." Edited by A. C. Seward, Cambridge (1909), p. 20 
Darwin regarded as taking the place of the human breeder in free nature, is not a direct struggle between carnivores and their prey, but is the assumed competition for survival between individuals of the same species, of which, on an average, only those survive to reproduce which have the greatest power of resistance, whilst the others, less favourably constituted, perish early." 1

Here, however, as in not a few other instances, Darwin is broader than many Darwinians. Although one of the sections in chapter iii. of "The Origin of Species" is headed "Struggle for Life most Severe between Individuals and Varieties of the same Species," the evidence given hardly justifies the title, and, in any case, another section is headed "The Term, Struggle for Existence, used in a Large Sense." In writing to Hooker in 1856, he said: "The slight differences selected, by which a race or species is at last formed, stand in a far more important relation to its associates than to external conditions"; but there are many passages in "The Origin of Species" which express the view that the struggle for existence as the method of Nature's sifting includes very much more than internecine competition between fellows. "I should premise," he says, " that I use this term ["struggle for existence"] in a large and metaphorical sense, including dependence of one being on another, and including (which is more important) not only the life of the individual, but success in leaving progeny."

1 The same view is expressed by Haeckel and Ray Lankester, but I am glad to find that, in his scholarly and judicial " Handbook of Darwinism," Prof. L. Plate interprets Darwin's conclusions and the state of affairs in nature in much the same way as $I$ have done. 
The position which we are seeking to define and defend is this. The concept " struggle for existence" is wider than is suggested by the words taken literally. It is a function of many independent variables. It expresses the reaction of living creatures to their limitations and difficulties. It means that living is rarely drifting, except for parasites. The physical world is careless of life; there is an extraordinary abundance of life; the river is always surging up to its embankments; love calls, hunger calls, and there is often no satisfaction ; there are many critical moments in growth and development, many risks of falling through holes in the Mirza bridge; the living creature has a will of its own-a will to live,-all this, and more, may be usefully condensed in the formula " struggle for existence."

Our thesis is that we have the struggle for existence wherever living creatures press up against limiting conditions; wherever living creatures, with their powers of growing and multiplying, thrusting and parrying, changing and being changed, do in any way say, "We will live."

The living creature is by its very essence assertive. If it cannot do anything else it will multiply. Life is an endeavour; it expands, it intrudes itself, it protests against limitations. One living creature presses upon another, competes with another, eats another. And for all this thrust and parry between living creatures and their limitations we use the formula-phrase "struggle for existence." Surely Darwin had this broad conception vividly in mind when he used that strange metaphor: "Nature may be compared to a surface on which rest ten thousand sharp wedges touching each other 
and driven inward by incessant blows "- the idea being that any wedge that was relieved from blows would at once rise above the rest. But the comparison to wedges is inadequate; we have to think of living wedges with a will of their own-a will to rise, and then we have got nearer the idea of the struggle for existence. The same idea is suggested by Darwin's extraordinary sentence: "It may metaphorically be said that natural selection is daily and hourly scrutinising throughout the world the slightest variations."

The Other Side of the Struggle for ExistENCE. - If we are right in our wide interpretation of the concept "struggle for existence," which we maintain to be Darwin's, though many biologists, such as Sir E. Ray Lankester, say it is not, then we can pass in a more logical way than heretofore to what has sometimes been called the other side of the struggle for existence: to a recognition of the love of mates, parental sacrifice, filial affection, the kindliness of kindred, gregariousness, sociality, co-operation, mutual aid, and altruism generally. These are facts of life, though we may differ as to the precise psychological terms to be used in describing them. The business of life, all through, includes care for others as well as care for self. As Herbert Spencer says: "If we define altruism as being all action which, in the normal course of things, benefits others instead of benefiting self, then, from the dawn of life, altruism has been no less essential than egoism. Though primarily it is dependent on egoism, yet secondarily egoism is dependent on it." "Self-sacrifice is no less primordial than self-preservation." As has been 
well said: "The purely self-seeking animal has been found to be a fiction, like that of the economic man" (Norman Wilde).

Our position is that, instead of making an antithesis between " struggle for others " and " struggle for self," it is clearer to recognise that both may be included in the rubric of reaction of self-assertive living creatures against the difficulties and limitations of environing conditions. In many cases a kin-instinct is as well defined as a self-preservative instinct, and, in face of difficulties and limitations, a solution may be found along either line or along both. The world is indeed the abode of the strong, but it is also the home of many feeble folk who make up in love what they lack in strength.

Mutual AID.-Kropotkin has done real service to science by showing, in detail, how much there is of mutual aid among animals. There are some genuine societies, where the whole is more than the sum of its parts and sometimes acts as a unity. Ants are little people, and all the world is against them; in facing their limitations-which is what "struggle" means-they have found a solution in sociability, and they are dreaded by much stronger insects. Every one knows that some species of ants go to war. But our outlook on nature should take its colour not only from the warfare, but also from the self-subordination which the whole life of the ant-hill illustrates. In many species it seems to be a law of the hill that an ant with a full crop must never refuse to feed a hungry comrade.

There is something very suggestive in an observation of Hudson's in regard to social and 
sociable animals higher up in the scale, the Viscachas-burrowing rodents of South America. When the farmer destroys a viscacha burrow and buries the inhabitants under a heap of earth, other viscachas, coming from a distance-for village often visits village-dig out those that are buried alive. There are thousands of similar facts, which go to show that there is much more in the animal world than a Hobbesian warfare-each for himself and extinction take the hindmost.

Besides animal societies in the stricter sense there are many flocks and herds-gregarious rather than social creatures; and what we know of their mode of life, though it is not nearly so precise as it ought to be, warrants us in saying that the vulgarisation of the Darwinian picture of the struggle for existence is inaccurate. There is an ugly proverb which says that a wolf is a wolf to other wolves, but Kipling's zoology is finer: there's a law of the pack which means self-subordination. We do not associate kites and vultures with fine feelings, but the Brazilian kite is said to summon its friends to the feast (when it is big enough), and one of the strongest vultures is called-not without good reason-the sociable vulture.

There are instances of co-operation among animals neither social nor gregarious; thus a dozen burying beetles may combine to transport a dead bird to soft ground. Every one knows that little birds, like wagtails, will combine to drive off a falcon, and there are many records of the frequent disappointment of birds of prey when they visit the lake-side crowded with ducks and terns and plovers. It is quite certain that the battle is not always to the strong. Another striking fact is the 
social character of migration in the case of many birds that usually live alone.

Besides sociality, gregariousness, and co-operation, there are the associations of the pair and the family, which evidently include much more than squabbling round the platter. The struggle for existence includes, as Darwin emphasised, "success in leaving progeny." Macgillivray found two thousand feathers in the nest of the long-tailed tit.

It goes without saying that mutual aid pays, and pays because there is a universal struggle for existence. We do not wish, therefore, to complicate the issue with psychological questions of egoism and altruism, self-regarding and other-regarding; nor do we wish to make an antithesis between mutual aid and mutual struggle; our point is that within the wide concept of Struggle-or Reaction to Limitations-there is included mutual aid, and that this mode of solution is attended with success-a success which is more than survival, for it spells progress as well. As Kropotkin says: "Mutual aid leads to mutual confidence, the first condition for courage, and to individual initiative, the first condition for intellectual progress." The intelligence of the social birds, like rooks, parrots, and cranes, has been the subject of admiration since natural history began.

Let us get away from mere words and into contact with facts. Animals get hungry, they seek their food, they endeavour to catch what often endeavours not to be caught, they compete with others who endeavour to catch the same elusive prey, they have also to keep an eye on those who are seeking to catch them while they are seeking to catch something else, and meanwhile they have 
to struggle to keep their foothold amid the storm of the careless physical environment. There are also struggles for mates and for the sake of offspring. Which of these endeavours is the struggle for existence? Each and all. For the real meaning of the phrase is to be found, not in picturing this or that kind of struggle or endeavour, but rather in the general idea of living organisms asserting themselves against limitations and difficulties, partly no doubt due to their immediate competitors of the same kin or even family, but by no means restricted to this.

Our thesis is that progress depends on much more than a squabble around the platter; that the struggle for existence is far more than an internecine competition at the margin of subsistence; that it includes all the multitudinous efforts for self and others between the poles of love and hunger; that it comprises all the endeavours of mate for mate, of parent for offspring, of kin for kin, as well as every detail of self-assertiveness ; that existence for many an animal means the well-being of a socially bound or kin-bound organism in a social milieu; that egoism is not satisfied until it becomes altruistic.

Application of the Concept to Human Life. -What has the Darwinian conception of the struggle for existence to do with human life?

(1) If Nature has any particular word to say to man that word is Endeavour. All through the ages we may see Nature's condemnation of "the unlit lamp and the ungirt loin." Nature is all for efficiency, and down on slackness.

(2) It has to be admitted, however, that, at juncture after juncture, Nature offers the alterna- 
tive of parasitism, and there are thousands of living creatures that have followed this line of least resistance with its reward of adult safety and complete material well-being, with its nemesis of degeneracy. To man also this alternative is offered, and it is not infrequently, in part at least, accepted, both by lower and by higher stocks, and always with inevitably attendant dangers. Let us recall Meredith's verse :

Behold the life of ease, it drifts.

The sharpened life commands its course:

She winnows, winnows roughly, sifts,

To dip her chosen in her source.

Contention is the vital force

Whence pluck they brain,-her prize of gifts.

(3) As among animals, so among men, disturbances of equilibrium and conflict of interests bring about struggle, and there are always two chief lines of solution (besides that of partial parasitism). The one is increased intensity of competition; the other is increased combination and mutual aid. From the biologist's point of view it is important to make clear that Nature has rewarded both these lines of solution with survival, and that the line of mutual aid and sociality has been especially justified by psychical progress. We may take it that, as it has been in the past, survival and progress will continue to be the rewards of those nations in which there is not only valour in competition (more and more shifted from the battlefields), but the virtue of loyal subordination of individual to communal interests.

(4) With the spread of civilisation the character of the struggle for existence among men has 
greatly changed, becoming less and less literal, less and less sustained. It is seldom allowed to work out to a finish, as it does in the animal world. As this is apt to result in a state of affairs in which the superior are defrauded of the rewards of superiority and the inferior are not mulcted for their inferiority-an unnatural state of affairs-it behoves man to secure that the literal struggle for existence is replaced by an endeavour after well-being, which will continue in a subtler, more rational, more humane form the automatic singling and sifting which goes on in Nature. 
CHAPTER IV

\section{THE RAW MATERIALS OF EVOLUTION}





\section{CHAPTER IV}

\section{THE RAW MATERIALS OF EVOLUTION}

Organic Progress Primarily depends on Variability-Darwin's Position-Progress since Darwin's Day in Regard to VariationVariations more Abundant than even Darwin supposedProportion between Frequency and Amount of Variations -Correlation of Variations-Brusque Variations more Frequent than was formerly supposed-Discontinuous VariationsMutations-Darwin's Position in Regard to Mutations-Origin of Variations-Germinal Selection-Variational StimuliModifications or Acquired Characters-Indirect Importance of Modifications - Modification-Species - Individual Plasticity Relation to Human Life.

Organic Progress Primarily depends on VARIABILITY.-The most difficult problem in biology - part of the persisting mystery of life itselfis the innate changefulness which we often see manifested in a family, a herd, or a seed-plot, when we compare one generation with another. Of how much interest and importance is this changefulness ! for it is among the inborn variations of living creatures that we find the raw materials of evolution.

Evolution implies change-change along a definite line, and it also implies a certain continuity throughout the change. Individual development, the growing of the mustard-seed into the greatest of herbs, the "minting and coining of the chick out of the egg," is progressive change in which the 
continuity is one of personal identity. In organic evolution the continuity is racial, not individual; but, as in development, there is progress in the wide sense. It may be up or down, for the better or for the worse, measured by certain standards, but progress of some sort is implied in the concept of evolution, and it is with the raw materials of progress that we are now concerned. The interest of this inquiry is enhanced by the fact that, throughout the ages, life has been on the whole slowly on the upgrade, and that among animals there has been a gradual emergence of greater control and more freedom, of a fuller life and higher intelligence.

Darwin's Position.-Darwin started from the admitted fact of life that offspring are often innately different from one another and from their parents. Through his study of specieswhich began in his boyish beetle-collecting and went on to his eight years' work on barnacleshe had become aware of the fountain of change in living creatures, and he strengthened his impression by patiently accumulating facts in regard to the variability of domesticated animals and cultivated plants. In his original 1858 essay, and in the "Origin of Species" (1859), he recognised two kinds of hereditary variations: (1) large "single variations," or "sports," which occur rarely and result in individuals conspicuously different from the type of the species; and (2), slight "individual variations," which are of frequent occurrence, distinguishing child from parent, brother from sister, or cousin from cousin. He was much interested in the large single variations, such as occurred in the origin of copper-beech and weeping willow, but-true to the influence 
of Lyell-he came to the conclusion that the minute ubiquitous "individual variations" were by far the more important. Fleeming Jenkin, Professor of Engineering in Edinburgh, pointed out that single large peculiarities would be likely to be swamped by inter-crossing, and this criticism had so much weight with Darwin that he ceased to attach importance to the larger divergences, and found his raw material in what he called "individual variations." "The more I work," he said, " the more I feel convinced it is by the accumulation of such extremely slight variations that new species arise."

In reference to both sports and small variation,s, Darwin used the terms " indefinite" and "spontaneous," to distinguish them from "definite variations," which are now called somatic modifications-i.e. definite and direct results of environmental or functional changes. Darwin believed in the occasional transmissibility of these " definite variations," and in so doing he agreed with Lamarck, whose work he does not seem to have adequately appreciated.

Progress since Darwin's Day in Regard to Variation.-While we must still confess, with Darwin, that in regard to the causes of variation our ignorance is immense, we have also to recognise that, in several directions, there is progress to report. For some time after the publication of "The Origin of Species" more attention was given to the directive than to the originative factors in evolution. The idea of selection fascinated naturalists, and it was too much the custom simply to postulate variability to meet the demands of particular problems. Life is so abundant and 
so Protean that biologists tended to draw upon the variability account as if there was no limit to it, scarce waiting to see whether their cheques were honoured. A lesson might have been taken from Darwin's painstaking study (1868) of variations in domesticated animals and cultivated plants, or from Mr. J. A. Allen's pioneer work (1871) in measuring American birds, but the vice of simply postulating variations when they were wanted for theoretical purpose persisted and has been wide-spread for fifty years.

In the preface to his "Materials for the Study of Variation" (1894), Bateson wrote: "We are continually stopped by such phrases as, 'if such and such a variation then took place and was favourable,' or, 'we may easily suppose circumstances in which such and such a variation, if it occurred, might be beneficial,' and the like. The whole argument is based on such assumptions as these-assumptions which, were they found in the arguments of Paley or of Butler, we could not too scornfully ridicule. . . . If we had before us the facts of variation there would be a body of evidence to which, in these matters of doubt, we could appeal. We should no longer say 'If variation take place in such a way,' or 'If such a variation were possible'; we should, on the contrary, be able to say, 'Since variation does, or at least may, take place in such a way,' 'Since such and such a variation is possible,' and we should be expected to quote a case, or cases, of such occurrence as an observed fact."

In the most general terms it may be said that one of the greatest steps of progress in evolutionlore since Darwin's day has been the accumulation 
of accurate data in regard to the variations that do actually occur. It is a tedious task, but peremptorily necessary, and already it is having its reward. The recording and statistical registration of variations-such as we find in the pages of the journal called Biometrika-is rapidly helping us out of the slough of vagueness, in which, to the physicist's contempt, biology is so apt to flounder. Let us try to state some of the general impressions that we get from the post-Darwinian study of variation.

(1) Variations more Abundant than even Darwin supposed.- "Even Darwin himself," as Wallace says, "did not realise how much and how universally wild species vary"; but one of the clear results of much patient work of recent years has been the proof that variations are as marked among creatures living wild in nature as they are among those under man's control. The fountain of change is even more copious than was dreamed of.

In commenting on the "fallacy of the belief that great variation is much rarer in wild than in domesticated animals," Mr. Bateson notes that " if we examine the variation in the vertebræ of the sloths, in the teeth of the anthropoid apes, in the colour of the dog-whelks (Purpura lapillus), etc., we find a frequency and a range of variation matched only by the most variable of domesticated animals." We get the same impression when we look at a good collection of cuckoo's eggs, or of land-snails, or of ruffs, and so on through a long list.

It is difficult to realise the frequency and amount of variations until one begins to measure and 
weigh. In $1871 \mathrm{Mr}$. J. A. Allen measured numerous individual representatives of some common species of American birds, and found that, as regards important points, e.g. length of bill and length of wing, birds of the same sex and season, caught at the same place, on the same day, showed numerous variations, often large in amount. "The facts of the case," Mr. Allen says, "show that variation of from 15 to 20 per cent. in general size, and an equal degree of variation in the relative size of different parts, may be ordinarily expected among specimens of the same species and sex taken at the same locality, while in some cases the variation is even greater than this."

(2) Proportion between Frequency and Amount of Variations.-Another fact has been made clear in regard to variations: there is a proportion between the frequency of a particular change and the amount of its departure from the mean of the character in question. In other words, the variations, when plotted out, show what is called the Curve of Frequency of Error. ${ }^{1}$ In

1 Quetelet (1846) showed that variation followed the law of frequency of error, the mathematical expression of which was discovered by Gauss. Sir John Herschel, in illustrating this, took the case of a rifleman aiming at a target. "It was pointed out that, irrespective of the skill of the rifleman, the shots, after a large number of trials, would be aggregated most thickly about the centre of the target, and would be more and more thinly scattered the farther the distance became from the centre of the target. The only difference between the targets of a good and of a bad rifleman is that in the former case the total area which contains all the shots would be snialler than in the latter case. But in each case the centre of the area would coincide with the centre of the target, and the distribution of shots within the area would be similar. The explanation of this result rests upon the circumstance that, each time the rifleman takes aim, a number of factors come into operation, tending to disturb the correctness 
measurements of 2,600 men, taken at random, Wallace notes that there is 1 of $4 \mathrm{ft}$. 8 in. and 1 of $6 \mathrm{ft}$. 8 in. ; 12 of $5 \mathrm{ft}$. and about 12 of $6 \mathrm{ft} .4 \mathrm{in}$. ; equal numbers at equal distances from the mean of $5 \mathrm{ft} .8 \mathrm{in}$.

This tedious work of registering the variations that occur may lead us right into the heart of the matter; thus the asymmetry or skewness of the curve may show us at a glance that the species is moving in a definite direction as regards the particular character measured, or the formation of a double-humped curve may vividly bring home the fact that the species is dividing into two sub-species. Thus, by a statistical path, we are brought face to face with the most vital of all facts-l'évolution créatrice.

(3) Correlation of Variations.-Another impression which we get from some of the modern work on variation is, that the living creature

of the alignment of the rifle. But as these factors act with equal frequency in every direction, it follows that the point of thickest distribution of the shots will still remain at the centre of the target. Now, variation is found to follow precisely the same law. If measurements of some character are taken in a large number of individuals, it is found that there is a mean measurement in the neighbourhood of which the individuals are most thickly clustered, and that the further the distance from the mean, the fewer are the individuals represented. The analogy goes yet farther: for, just as in the case of the good and bad riflemen, we found the shots to be in close juxtaposition or more widely scattered, so in the case of variation, it is found that the divergences from the mean are in some cases far more accentuated than in other cases; that is to say, the degree of constancy or variation in different organs is very different. But in all cases the variation can be represented by a geometrical curve, the ordinates of which are proportional to the terms in the expansion of the binomial $(a+b)$. Occasionally the individuals are found to cluster round two or more points of thickest distribution, and it is then inferred that they belong to two or more different races,"-Edinburgh Reriew, Jan, 1909. 
varies, in many cases, as a unity, not in this corner and that-like a machine that is perfected by the accumulation of little patents, - but through and through and all at once. As Darwin pointed out, there is a "correlation of variations." One change brings another in its train, and the one that is for the time most important may evolve another much more important. Thus a variation too small in itself to be of value may be carried over the dead point into effectiveness because it is physiologically bound up with another variation.

Another aspect of the same idea is that what seem to be new departures in widely separated parts of the animal may be really diverse outcrops of one deep physiological change. We may have thought of this in connection with some disease that we have watched: it has very different expressions in different parts of the body, though it is due to a single slight derangement in the normal sequence of chemical events. We may have thought of the same idea in connection with sex, where changes apparently confined to minute and superficial and unconnected parts may be, as it were, the correlated outcrop of one deep physiological change. ${ }^{1}$ It is a familiar fact that numerous apparently distant and unconnected changes of adolescence are all fundamentally one. Similarly, when an individual plant or animal varies as a whole, when compared with its parent, this means that the potential individual, the germ-cell, has varied as a unity.

(4) Brusque Variations more Frequent than was formerly supposed.-But the most important

1 "The Evolution of Sex," by P. Geddes and J. Arthur Thomson, "Contemporary Science Series" (1889). Revised Edition (1901). 
general result of the modern study of variability is the evidence that changes of considerable amount sometimes occur at a single leap. These brusque changes are called "discontinuous variations," and, in certain cases, "mutations." Lamarck said, "Nature is never brusque," and we usually look askance at reports of "Jack-inthe-Box" phenomena in nature; but, through the solid work of Bateson, De Vries, and others, there is more reason to-day than there was fifty years ago to believe that organic structure may pass with seeming abruptness from one position of organic equilibrium to another.

Discontinuous Variations.-In the individual development of an embryo there is gradual continuous change from hour to hour, from day to day; and if we suppose similar changes to occur, not as normal stages in the development of one creature, but as new steps of progress in successive generations of creatures, we have the individual variations that Darwin most believed in as furnishing the raw materials of evolution. But in many a development, such as that of a starfish or a butterfly, there is in a certain sense discontinuity; there is a crisis, when the developing creature recommences on a new track; and this sort of change occurring, not as a normal event in individual development, but as a new departure in racial evolution, would be a " discontinuous variation." Using Galton's simile, we can picture a polyhedron oscillating or rocking on one of its faces: this would be an " individual variation," or fluctuation; we can also picture it rolling over to a position of equilibrium on another face: this would be "discontinuous variation," or mutation, 
The greatest contribution in this connection is Bateson's work entitled, "Materials for the Study of Variation," which showed that discontinuous variations of certain kinds are not uncommon. Abundant evidence is given of "the existence of sudden and discontinuous variation; the existence, that is to say, of new forms having from their first beginning more or less of the kind of perfection that we associate with normality."

Mutations.-The idea that the Proteus may leap as well as creep is prominent in the work of the Dutch botanist De Vries, embodied in his "Mutations-Theorie." De Vries tells the story, for instance, of a stock of the evening primrose (Enothera lamarckiana), which he found as an escape in a potato-field near Amsterdam. It was, as it were, frolicking in its freedom ; " sporting," as we say. Almost all its organs were varying, as if swayed by a restless, internal tide. It showed minute fluctuations from generation to generation; it showed extraordinary freaks, such as fasciation and pitcher-forming; it showed hesitancy as to how long it meant to live, for while most were biennial, many were annual, and a few were triennial; best of all, it showed what seemed like new species in the making. From this stock De Vries obtained, in a short time, half a dozen or more distinct varieties or elementary species, breeding true generation after generation. He was led to the important conclusion that " new varieties are produced from existing forms by sudden leaps." 1

1 It is unfortunate that nothing certain is known as to the origin of Enothera lamarckiana, which has been in cultivation for a long time. It is possible that its "mutations" result from the impurity of the stock, As Prof. S, J, Holmes says, in an interesting 
The first part of the Dutch botanist's great work was published forty-three years after "The Origin of Species," and there are many who regard the Mutation Theory and Mendelism as the two greatest steps of progress that have been made in evolution-lore since 1859. Others, such as Alfred Russel Wallace, the Nestor of the evolutionist camp, are very far from sharing this view. In any case we must try to understand what mutations are and what their significance may be.

The general idea is that novel characters may suddenly appear, as it were, full-fledged, with considerable perfectness from the moment of their emergence, and without intergrades linking them to the parents. Furthermore, the novel character of the mutant, if we may use the word, is independently heritable and does not blend; it can be grafted intactly on to another stock, or it can be dropped out as such. Again, mutations are what may be called qualitative, as contrasted with the fluctuations which are quantitative. Thus, some of the new evening primroses which De Vries got out of his changeful stock of Enothera lamarckiana were very different from the parent type-some had few branches instead of many, some had small flowers instead of large, some had quite different leaves, and so on. Mutations have been recorded for a number of other plants, such as violets and shepherd's purse; but the inquiry is still young.

Among animals in nature we know as yet of few

paper on " The Categories of Variation" (American Naturalist (1909), vol. xliii. p. 277): "Should it turn out to be derived from a mixture of two or more forms, the mutation theory would be deprived of some of its best evidence; but there would still remain a con. siderable number of mutations from pure ancestry." 
sudden emergences of qualitatively new characters, but several cases have been reported. Thus pink katydids may abruptly appear among green ones, and short-winged insects in a long-winged race, in both cases without intergrades. Mutations are also described among freshwater fishes and among medusæ.

When we turn, however, to domesticated animals, where we have greater opportunities of intimate observation, the case for mutation becomes stronger. There are sudden negative changesthe entire dropping out of a character-as seen in the abrupt appearance of hornless cattle, sheep, and goats, of hairless dogs and horses, of tailless cats and dogs. There are also sudden positive changes - the acquisition of a new character-such as the appearance of extra digits in poultry and pigs. Those who have bred birds are familiar with such sports, which are often striking. There is evidence in a number of cases that stable and successful breeds have been established, not by the slow increase of minute fluctuations, but by getting a big start in a mutation. In many cases, although breeding or cultivation has grafted the novelty on to a strong stock and made it prepotent, it has not greatly increased the magnitude of the quality which the original sport exhibited.

Darwin's Position in Regard to Mutations. -Though Darwin had not the conception of unit characters - that is to say, independently heritable characters which are handed on intact or dropped out altogether-in its modern clear-cut form, he was well acquainted with mutations in domesticated animals and cultivated plants, and he dismissed most of them as not important. In the first place, 
they seemed to him to partake too much of the pathological. But we must not hurriedly dismiss mutations like that of fowls with webbed feet and no tails as obviously teratological, for most of them may be matched in nature. If there were only one specimen of a cross-bill, for instance, would it not be regarded as a freak which could not possibly survive in nature? In the second place, reacting as he was against a catastrophic view of nature, and looking at things (as he said) through Lyell's ${ }^{1}$ eyes, Darwin naturally fought shy of big sudden changes. Moreover, as he said to Asa Gray: "There seems to me in almost every case too much, too complex, and too beautiful adaptation in every structure to believe in its sudden production." Finally, he thought that a fullfledged new character appearing suddenly would be swamped by intercrossing. ${ }^{2}$

The last difficulty, which is the only serious one, has been removed, for it is characteristic of mutations that, when they arrive, they come to stay, unless they be eliminated as disadvantageous. In

1 It was characteristic of the Lyellian, or Uniformitarian school of geologists to explain large results on the principle of slow suocessive increments, accumulating for a very long time.

2 Let us hear what he says in the last edition of "The Origin of Species" :

"Mr. Mivart is further inclined to believe, and some naturalists agree with him, that new species manifest themselves ' with sudden. ness and by modifications appearing at once....' This conclusion, which implies great breaks or discontinuity in the series, appears to me improbable in the highest degree" (p. 201).

"Although very many species have almost certainly been produced by steps not greater than those separating fine varieties, yet it may be maintained that some have been developed in a different and abrupt manner. Such an admission, however, ought not to be made without strong evidence being assigned" (p. 203). 
other words, a new unit character of a beetle or of a shepherd's purse-two experimentally tested instances-does not blend when its possessor is crossed with the original type. It is not swamped by intercrossing, but reappears in its integrity in a definite proportion of the succeeding generations. Already in actual practice in wheat-growing it is being found that selected single ears breed true, and that no further selection is needed.

The attractiveness of the mutation theory is so great that we must be particularly cautious in our acceptance of it. It would relieve the difficulties that many naturalists have in believing that the apparent big lifts and qualitative changes which the history of organic life implies have arisen by the natural selection of minute individual fluctuations. It would make more intelligible the discontinuity of many species, if we found reason to believe in their saltatory origin. It need hardly be said that the origin of the mutation would remain a mystery, for the mutation theory is not a theory of mutations. It will be interesting if evidence accumulate to show that the Proteus leaps as well as creeps, if future generations look back to Darwin as the naturalist who saw nature moving by small steps, while Dr. Vries caught a glimpse of her dancing !

ORIGIN OF VARIATIONS. - In regard to the difficult question of the origin of variations, we must not be impatient to answer until our knowledge of their nature has greatly increased. We must still confess, with Darwin : "Our ignorance of the laws of variation is profound. Not in one case out of a hundred can we pretend to assign any reason why this or that part has varied." And again he said: 
"If, as I must think, external characters produce little direct effect, what the devil determines each particular variation?"

Having made this confession of ignorance, we venture to discuss the possibilities of answer to a question which can never be far from any thoughtful mind.

There are variations and variations. There are variations that mean nothing more than an augmentation or diminution of an already existing quality. The hair may be very long or the tail very short. Or a variation may mean that a character present in parents and ancestry is absent from the offspring: the entail has been broken. An albino expresses such a variation, or a hornless calf, or a tailless kitten. Or, again, a variation may be interpretable as a novel arrangement of characters or qualities which were present in the ancestry. A piebald pony may serve as a diagram.

Now, in regard to variations of this sortwhich may be described as permutations and combinations of the already existing unit characters-the modern knowledge of the conditions of heredity has made it plain that there are many opportunities for their occurrence before, during, and after fertilisation. We know that each germcell contains a definite number of stainable bodies, or chromosomes, which appear to be the bearers of the heritable qualities. We may compare these to a microscopic pack of cards, and we may say th there is an extraordinarily elaborate shuffling betore development begins. Half of the pack is ejected from the egg-cell in what is known as a "polar body," and the number is raised to the normal again (constant throughout the body of the 
organism) by the entrance of the fertilising spermatozoon whose chromosomes have also been reduced by a half. In fertilisation, at the beginning of each new life, there is an intricacy of combination that may be likened to the making of a living mosaic out of parental and ancestral contributions. It may also be that in the making of the germcells there is a segregation of antithetic qualities, so that two different kinds of germ-cells result, corresponding to the two sharply contrasted parents. It may also be, as Weismann supposes, that there is a struggle between rival unit-characters in the penetralia of the germ-cells. In any case, there is abundant opportunity for new permutations and combinations. There are many factors which may give the vital kaleidoscope a twist.

There is, however, another kind of variation, when novel features appear, which are qualitative rather than quantitative, substantive rather than architectural, in kind rather than in degree, and more than mere rearrangements of previously expressed unit characters. What can be said as to their origin?

Weismann and others have suggested that the stimulus to germinal variations comes from the oscillations and changes in the immediate surroundings of the germ-cells. They get their foodsupply from the body, and that food-supply is liable to be somewhat variable. It may contain a poison, for instance, which seriously shakes the architecture of the germ-plasm at the very start; but it may also contain some stimulus, which provokes the living germ to a new departure. 
Another suggestion, which has some interesting experimental evidence behind it, is that important changes in the environment-changes in chemical composition, heat, light, and electrical conditions, and so on-may saturate deeply through the body and stimulate the germ-cell to change. We shall return to this suggestion later on.

Germinal Selection.-In his theory of "germinal selection" Weismann has elaborated an interesting speculation in regard to the roots of variation. With his characteristic way of following an idea as far as it will lead him, he has extended the concepts of struggle and selection to the primary constituents (or determinants) within the germ-cell. In consequence of unequal nutrition these primary constituents are always varying. If one of them, corresponding, let us say, to a sensecell, receives for a considerable time more abundant food than before, it will grow in proportion, and if the germ-cell develops into an organism the sensory cell may be twice as strong as it was in the parent.

But the strengthened determinant may begin actively to nourish itself more abundantlyattracting the food to itself, and in some measure withdrawing it from its fellow-determinants. In this way "it may get into a permanent upward movement, and attain a degree of strength from which there is no falling back."

In a similar manner a downward variation of a determinant may be started by diminished nutrition, and the weakened determinant will have less affinity for attracting nutriment because of its diminished strength. "If a certain critical stage of downward progress be passed, even 
favourable conditions of food-supply will no longer suffice permanently to change the direction of the variation."

If, in such a case, the determinant be that of a useful structure, then the ordinary process of natural selection will remove the individual; but if the weakened determinant be that of a useless organ it will continue getting weaker generation after generation.

"In most cases the fluctuations will counteract one another, because the passive streams of nutriment soon change; but in many cases the limit from which a return is possible will be passed, and then the determinants concerned will continue to vary in the same direction till they attain positive or negative selection-value. At this stage personal selection intervenes and sets aside the variation if it is disadvantageous, or favoursthat is to say, preserves - it if it is advantageous. But the determinant of a useless organ is uninfluenced by personal selection, and, as experience shows, it sinks downwards; that is, the organ that corresponds to it degenerates very slowly but uninterruptedly till, after what must obviously be an immense stretch of time, it disappears from the germ-plasm altogether." Thus "germinal selection supplies the stones out of which personal selection builds her temples and palaces: adaptations." 1

The theory is, of course, entirely hypothetical, dealing as it does with the invisible, but it enables us to formulate a large number of facts.

Variational Stimuli.-Some of the most interesting and striking work of the last dozen years

1 "The Evolution Theory," by Weismann (1904), vol. ii. 
must be referred to in connection with the origin of variations. It has been shown experimentally that chemical substances in the food of the mother may be carried on into the offspring. Thus, when the dye known as Sudan is mixed with the food of hens, it appears in the yolk of the egg and eventually in the fatty tissue of the chick. Perhaps this sort of thing is commoner than is usually supposed. By changing the temperature and the food of the caterpillars of Vanessa and Arctia, Standfuss and Fischer were able to induce, in the next generation, aberrant characters, which remained distinct when crossed with the parent form.

More striking, however, are the experiments carried on for twelve years by Professor Tower on beetles of the genus Leptinotarsa, which he subjected to unusual conditions of temperature and moisture when the male or female reproductive organs were at a fixed point in their development. The result was to induce in the offspring striking changes, not only in colour and markings, but also in some details of structure. Sometimes all the germ-cells seemed to be affected, sometimes only a fraction of them ; sometimes various changes resulted from the same treatment; some of the changes were brusque, others showed intergrades with the parental conditions; sometimes the change did not occur until after the lapse of several generations in the unusual environment; there was no reversion to the parental condition. Of course Tower could not get at the reproductive organs except through the body, but it should be noted that the body of the parent was not changed, and it was only at particular stages 
that the influence was operative. Here, then, we have definite evidence of germinal variation evoked by environmental stimulus.

Very interesting, also, are the experiments of Dr. C. S. Gager, who exposed the egg-cells and pollencells of Onagra biennis to Radium rays, and found that plants grown from the seeds produced under this influence were very different from the parents, and that the change persisted to the second generation at least. Here, again, there is proof of heritable variation induced by environmental stimulus.

Shortly before his death Darwin began to experiment on the possibility of producing galls artificially. "He imagined to himself wonderful galls caused to appear on the ovaries of plants, and by these means he thought it possible that the seed might be influenced, and thus new varieties arise." 1 What Darwin just began has been carried out with great skill by Prof. D. T. MacDougal. "Among other operations, solutions of sugar, calcium, potassium, and zinc were injected by the use of hypodermic syringes into the developing ovaries of Raimannia, one of the evening primroses, early in 1905, with the result that, out of several hundreds of seeds borne by the treated ovaries, sixteen individuals were found to be notably atypic, among other characters lacking the trichomes which are so conspicuous with the parental form. These reproduced themselves in the second and third generations, coming true to the newly-assumed characters." " Similar experiments were made with Enothera

1 "Life and Letters of Charles Darwin," vol. ii. p. 517.

2 "The Direct Influence of Environment," by D. T. MacDougal, in "Fifty Years of Darwinism" (1909). 
biennis and Penstemon wrightii, and we have decisive evidence that environmental stimulus acting directly on the germ-cells may induce striking variations. This is a very important result, for it is evident that the germ-cells of animals may in a similar way be naturally stimulated to vary by chemical changes in the vascular fluids. With the flowers, as with the beetles, there were not only losses and augmentations of what was previously present, but there were distinct novelties which maintained their distinctness when crossed with the parental strains.

After we have worked for years along the lines of these various suggestions that have been offered as to the causes of variations, we shall be better able to say how far they account for what we believe has occurred in the past, and for what we know to occur at present. Perhaps they will prove insufficient, and evolutionists will be forced to recognise that variability is, like growth, a primary quality of living things, and that "breeding true" has arisen secondarily as a restriction. The relation of genetic continuity between successive generations is an economical arrangement which secures relative constancy amid continual flux, but in spite of this the Proteus continually asserts itself. Its essence is creative power. It lives because it changes, it changes because it lives. From generation to generation there is a continuous lineage of germ-cells; but just as we see a youth growing and changing, taking time into himself and making himself, in some ways, new by his experience, so it may be that there is a power of growing and varying inherent in the germcells-as also in the unicellular organisms in the 
waters-which requires only time and experience to produce what is new.

Modifications, or Acquired Characters.We must now ask a very important question. Are there no other raw materials of evolution besides those inborn changes which we call variations and mutations, which we trace back to more or less mysterious processes occurring in the germinal material ? It is well known that our bodies suffer change according to what we do or do not do, and according to climate and food, and so forth. Does this sort of change not furnish part of the raw material of evolution?

Among the observed differences which mark man from man, or trout from trout, or buttercup from buttercup, there are many to which we cannot apply the word "variation." For, apart from constitutional or inborn changes, there are differences which are impressed upon the body in the course of life by influences from without, such as sun-burning in man or colour in trout; or by use and disuse, such as callosities on the fingers. These do indeed presuppose a constitution capable of being changed, but we can relate each to some definite influence, either of function or of environment, which has brought about a structural change transcending the limits of organic elasticity. We call these modifications, and though they may be of much importance to the individuals possessing them, they are not known to be of any direct importance in the evolution of the race, for the simple reason that there is no convincing evidence that they can be transmitted. Here the Lamarckians entirely dissent; but they have still to prove their case. 
After much discussion most naturalists have come back to the position of Kant, that life does not run on a compound interest principle of adding to the child's inheritance the individual acquisitions (somatogenic or exogenous modifications) of the parents. As a matter of fact, we do not know of any clear case of individual modifications due to surroundings, education, work, or sloth, being transmitted in any degree to offspring. That the parents' mode of life influences the children yet unborn is obvious; but the point is, whether the influence produces a corresponding or representative effect.

Indirect Importance OF Modifications.Those who find no warrant for accepting the Lamarckian postulate of the transmissibility of modifications, do not thereby assert that modifications are of no importance. Many living creatures are exceedingly plastic, and their modifiability sometimes saves them where their variability is at fault. This idea has been elaborated independently by Profs. Mark Baldwin, Lloyd Morgan, and H. F. Osborn, and we venture to quote Lloyd Morgan's terse summary:

(1) Variations (V) occur, some of which are in the direction of increased adaptation $(+)$, others in the direction of decreased adaptation (-). (2) Acquired modifications (M) also occur. Some of these are in the direction of increased accommodation to circumstances $(t)$, while others are in the direction of diminished accommodation ( - ). Four major combinations are-
(a) $+\mathrm{V}$ with $+\mathrm{M}$
(c) $-\mathrm{V}$ with $+\mathrm{M}$
(b) $+\mathrm{V}$ with $-\mathrm{M}$.
(d) $-V$ with $-M$. 
Of these $(d)$ must inevitably be eliminated while (a) are selected. The predominant survival of (a) entails the survival of the adaptive variations which are inherited. The contributory acquisitions $+M$ are not inherited; but they are none the less factors in determining the survival of the coincident variations." Lamarckians believe that useful modifications are in some degree sometimes transmitted. On the view just sketched the modifications are the screens or nurses of coincident variations in the same direction.

We can imagine conditions where swarthiness was a character of life-saving value, where the possessors of inborn variations in the direction of swarthiness were favoured, where those who varied in the direction of increased blondeness were handicapped. It is readily intelligible that those who could acquire swarthiness as an individual somatic modification would also be favoured, and that the acquired swarthiness might act as a lifesaving screen until constitutional and heritable swarthiness had time to establish itself.

Furthermore, although modifications may not be entailed, they may have occasionally important indirect influences on the offspring. A starved mother may have a weakly child.

ModifiCATION-SPECIES.- In the case of animals and plants which we do not know except in particular surroundings, it is quite possible that characters which we credit to inherited nature may be impressed on every successive generation by nurture. Especially among the more vegetative forms of life we find indications, which experiment will some day test, that there are what may be called " modification-species," which differ from 
nearly related species only because the conditions of their life are different.

Individual Plasticity.-At all events, there is great interest in individual plasticity, in what can be effected by changes in nurture. We must picture the living creature as continually running the gauntlet of the mechanical, chemical, physical, and even animate influences that make ur its environment. It passes over a series of anvils, on each of which the hammers ring a different tune. Let us take a few illustrations from among the many.

If the alkalinity of the sea-water be slightly altered, the egg of a sea-urchin allows itself to be fertilised by the sperm of a starfish, or of a crinoid, or of a mollusc (!), producing larvæ which all take after the mother.

If the chemical and physical state of the seawater be slightly disturbed, artificial parthenogenesis can be induced in starfish and sea-urchin, in worm and mollusc.

Sometimes the result of a slight chemical change is very perplexing, and there are many experiments at which we look with bated breath. Quaint abnormal larvæ of sea-urchin and frog are obtained by adding a little lithium to the water, and the addition of a little magnesium to the sea-water containing embryos of the fish Fundulus heteroclitus induces in a large number of these the development of a single Cyclopean eye in place of the normal two eyes. ${ }^{1}$

A small Crustacean called Gammarus, very common in fresh water, has the habit of avoiding

1 Charles R. Stockard, in Journal of Experimental Zoology, February 1909 . 
the light, but add a little acid so that the solution is no stronger than $\frac{72}{1000}$ th of one per cent., and Gammarus swims towards the light.

Remove one or two of the metals from seawater, keeping up the alkalinity, and the seaurchin egg develops into twins. Raising the temperature a little often has the same result.

Cold slows growth and development, yet the population of floating and drifting animals is denser in the Arctic waters than in the Tropicsa curious fact which Prof. Loeb explains by showing that lowering the temperature greatly increases the duration of life. There are more generations living at the same time. Lowering the temperature of the caterpillar box may be followed by curious aberrations of colour in the moths and butterflies, especially in the direction of melanism (Standfuss, Fischer, and others). Prof. Poulton showed that the caterpillars of the small tortoise-shell, for instance, are for a short time so sensitive that those in a white or gilded box have light or golden pupæ, while those from the dark box have dark pupæ.

The influence of diet alone might form the subject of a course of lectures. Take the simple but very suggestive fact reported by Marchal that a scaleinsect, Lecanium corni, becomes $L$. robiniarum when reared on Robinia pseudoacacia instead of on its own normal food-plant, though the reverse experiment does not succeed. Or consider one of the most interesting of recent researches. Mr. C. W. Beebe ${ }^{1}$ caused the scarlet tanager (Piranga erythromelas) and the bobolink (Dolichonyx oryzivorus) to keep their breeding plumage through

1 American Naturaliet (1908), vol. xlii. p. 34. 
the year by giving them fattening food and keeping them without much exercise in dim light. Gradual return to the light and the addition of mealworms to the menu brought back the spring song, even in mid-winter. After a year, and at the beginning of the normal breeding season, individual tanagers and bobolinks were gradually brought under normal conditions and activities, and in every case they moulted from nuptial plumage to nuptial plumage, the dull colours of the winter season having been skipped. The inherited constitution determines what is possible, but there is evidently a large range of plasticity. We do not know that modifications are entailed, but we must attach all the more importance to the influence of the environment in bringing about individual adjustment, in stimulating variation, and in punctuating developmental processes.

Relation to Human Life.--What has all this discussion regarding fluctuations and variations and mutations and modifications to do with human life? It would be easier to answer this question if we knew more about these changes, but some practical considerations are obvious.

To begin with, man probably arose by a mutation; that is to say, by a discontinuous variation of considerable magnitude. Every one who has known a genius has in this happy experience some idea of what is meant by a mutation, though the comparison breaks down inasmuch as the quality of genius is rarely heritable. It is not merely that the genius has more brains; he has a new pattern of brains, and a large mutation is a new constitutional pattern. It is likely that man had his starting-point as a prepotent anthropoid genius. 
Man's origin is hidden, and, whatever our ancestry was, we cannot change it; man's future is also hidden, but it will be, in some measure, of our making. Now, it is evident that some variations are undesirable: they make their possesion miserable, and his neighbours hardly less miserable. We admit that there is an "optimism of pathology"; unpromising buds may burst into flowers as fair as they are unexpected, weaklings bend Titans to their will, cripples make the world go round, and those of marred visage teach us what beauty really is; but, with all the breadth of view that biology will allow, there are some variations on which the verdict of history is that they make for retrogression. Every one wishes these variations to die out.

There are other variations that are unmistakably desirable-in the direction of fine physique, artistic skill, keen mental ability, originality, socialised disposition, and strength of character. Every one wishes these variations to be widely distributed.

Inquiry into the history of good animal stocks shows that steady progress has always rewarded the mating of nearly related forms, while the blending of distant and incompatible types seems often to lead to reversionary mongrels. Here we have a warning to the thoughtless experimenter with his own stock.

One of the characteristics that should distinguish the biologist is an expectancy, an openmindedness, a tolerance, even a reverence, with respect to variations; for these new departures on the part of the ever-changing organism are the raw materials of progress, and should be sedulously guarded. Individuality is often born, often 
smothered, rarely made. A man with an idiosyncrasy, who is snubbed as an impossible person, may be a Moses who might have led us out of bondage! Captain Fitzroy nearly refused to take Darwin on the Beagle voyage because of his nose!

For vorious reasons biologists take a strong interest in the play of animals and of children. Play is no mere safety-valve for overflowing animal spirits : it is a rehearsal, without responsibilities, of some of the essential activities of adult life. But it is more: it affords what the Germans call Abänderungspielraum-playground for variations. The playing organisms are the most educable.

The distinction between variations and modifications seems sometimes academic and tiresome, but if we understand it we see it as one of the most practical of questions. Do the innate changes in the natural inheritance furnish the whole raw material of progress, or do the changes in the body due to peculiarities of nurture furnish some? At present the scientific answer seems to be, that the raw material of organic evolution is due to variations, and in no direct way due to modifications. How closely this touches human life! There is social evolution as well as organic evolution, and social evolution has provided an apparatus whereby the gains of experience may swell the legacy of successive generations, although they do not, from the nature of the case, become part of the germinal inheritance.

As Lloyd Morgan ${ }^{1}$ well says: "The history of

1 "Mental Factors in Evolution," in "Darwinism and Modern Science" (1909), p. 445. 
human progress has been mainly the history of man's higher educability, the products of which he has projected on to his environment. This educability remains, on the average, what it was a dozen generations ago; but the thought-woven tapestry of his surroundings is refashioned and improved by each succeeding generation."

- "Few men have in greater measure enriched the thought-environment with which it is the aim of education to bring educable human beings into vital contact than has Charles Darwin." 


\section{CHAPTER V \\ FACTS OF INHERITANCE}





\section{CHAPTER V}

\section{FACTS OF INHERITANCE}

Progress during the Darwinian Era-Demonstration of Heritable Qualities-Heredity, a Term for the Genetic Relation between Successive Generations-Appreciation of Distinction between Nature and Nurture-The Idea of the Continuity of Generations-Critical Attitude in Regard to Various ConclusionsMendelism-Methods of Studying Heredity-Microscopical Study of the Germ-cells-Statistical Study : Filial Regression -Galton's Law of Ancestral Inheritance-Experimental Study -Pairing of Similar Pure-bred Forms-Blending-Particulate Inheritance-Exclusive Inheritance-Reversion-New Departures-Mendelian Inheritance-Unit Characters-The Case of Andalusian Fowls-Waltzing Mice-Occurrence of Mendelian Inheritance-Practical Importance of Mendelism-Much Progress but Great Uncertainty-Transmission of Acquired Characters-Disease-Facts and Possibilities-A Striking Case - Logical Position of the Question-Cases where the Theory of Modification-inheritance is Inapplicable-Importance of Environment and Function Remains-Selection and Stimulus -Indirect Importance of Modifications-Practical Import of the Question as to the Transmission of Acquired CharactersInheritance of Moral Character-Three General Conclusions.

Even in ancient times men pondered over the resemblances and differences between children and their parents, and wondered as to the nature of the bond which links generation to generation; but, although a recognition of these problems is old, the precise study of them is altogether modern, and may almost be called Darwinian. For it was largely through Darwin's influence that the scientific study of heredity began. "Before and after Darwin," Professor Osborn says, "will always be 
the anteet post urbem conditam of biological history"; so it may be useful to inquire into the advances that have been made in the study of heredity since the beginning of Darwin's day. ${ }^{1}$

Progress during the Darwinian Era. Demonstration of Heritable Qualities.-Before 1859 much attention was given to the demonstration of the general fact of inheritance. In a large treatise like that of Prosper Lucas (1847) many hundreds of pages are devoted to proving, what we now take for granted-that our start in life is no haphazard affair, but rigorously determined by our parents and ancestors; that various peculiarities, important and trivial, useful and disadvantageous, reappear as part of the inheritance generation after generation.

This demonstration of heritability is still going on in reference to particular qualities; thus we have Prof. Karl Pearson's evidence in regard to such subtle qualities as longevity and fecundity, and his indirect proof that mental qualities illustrate the same law of inheritance as bodily qualities. It is very desirable that more data should be accumulated in regard to the heritability of variations, whether Darwin's “ individual variations," or De Vries's " mutations." On the whole, however, it may be said that, since Darwin's day, sufficient evidence has been gathered to justify us in saying that any kind of character which appears as an inborn feature in an organism may be transmitted to the next generation.

(2) "Heredity" a Term for the Genetic Rela-

1 See, for a detailed discussion of what is dealt with briefly in this chapter, the author's treatise "Heredity" (Murray. London, 1908). 
tion between Successive Generations.-Another step is, that we are learning not to spell heredity with a capital " $h$." We no longer think of it as a power or as a principle, as a fate or as one of the forces of nature; we study it as a genetic relation which is sustained by a visible material basis, as a relation of resemblances and differences which can be measured and weighed, or in some way computed. In regard to property there is a clear distinction between the heir and the estate which he inherits; but at the beginning of an individual life there is biologically no such distinction. The organism and its inheritance are, to begin with, one and the same. We inherit ourselves. Thus "heredity" is simply a convenient term for the genetic relation between successive generations, and inheritance includes all that the organism is, or has, to start with in virtue of its hereditary relation.

(3) Appreciation of Distinction between "Nature" and "Nurture."-Another step, following on the last, is that we have begun to realise more clearly the distinction implied in the words "nature" and "nurture"-a distinction made by Shakespeare and definitised by Galton. The fertilised egg-cell contains, in some way which we cannot picture, the potentiality of a particular living creature - a tree, a daisy, a horse, a man. If this inheritance is to be realised there must be an appropriate environment, supplying food and oxygen and necessarystimuli of many kinds. Without this nurture the inherited nature can achieve nothing. The development of every character implies the interaction of the two sets of factorsthe internal organisation and the external environment. But the surrounding influencesare often very 
changeful, and the nature of the young organism may be profoundly modified by them. Thus we try to distinguish - and it is of enormous practical as well as theoretical importance-between the expression of hereditary nature realised in normal nurture and the individually acquired modifications which are due to changes or peculiarities in that nurture. The characters of a newly hatched chick stepping out of the imprisoning egg-shell are in the main strictly hereditary; but they need not be altogether so, for during the three weeks before hatching there has been some opportunity for peculiarities in the environment to leave their mark on the developing creature. Still more is this the case with the typical mammalian embryo, which develops often for many months as a sort of internal parasite within the mother, in a complex and variable environment. And as life goes on, peculiarities due to nurture continue to be superimposed on the hereditary qualities, especially when the creature trades with time, and, by choosing its own nurture, creates for itself an individuality.

(4) The Idea of the Continuity of Generations. -Another step is the general acceptance of a somewhat subtle and yet essentially simple idea, which may be called the continuity of generations. $^{1}$. There is a sense, Galton says, in which the child is as old as the parent, for when the parent's body is developing from the fertilised ovum a residue of unaltered germinal material is

1 In his address "Fifty Years of Darwinism," Prof. Poulton says : "The greatest change in evolutionary thought since the publication of the 'Origin' was wrought, after Darwin's death, by the appearance of that wonderful and beautiful theory of heredity, which looks on parents as the elder brother and sister of their children." 
kept apart to form the reproductive cells, one of which may become the starting-point of a child. In many cases, scattered through the animal kingdom, from worms to fishes, the beginning of the lineage of germ-cells is demonstrable in very early stages before the division of labour implied in building up the body has more than begun. Let us suppose that the fertilised ovum has certain qualities, $a, b, c, \ldots x, y, z$; it divides and redivides, and a body is built up; the cells of this body exhibit division of labour and the structural side of this, which we call differentiation; they lose their likeness to the ovum and to the first results of the cleavage of the ovum. In some of the body-cells the qualities $a, b$ find predominant expression; in others the qualities $y, z$; and so on. But if, meanwhile, there be certain germcells which do not differentiate, which retain the qualities $a, b, c, \ldots x, y, z$ unaltered, these will be in a position by-and-by to develop into an organism like that which bears them. Similar material to start with, similar conditions in which to develop-therefore, like tends to beget like. To use Weismann's words: "In development a part of the germ-plasm (i.e. the essential germinal material) contained in the parent egg-cell is not used up in the construction of the body of the offspring, but is reserved unchanged for the formation of the germ-cells of the following generation." Thus the parent is rather the trustee of the germplasm than the producer of the child. In a new sense, the child is a "chip of the old block." "'

May we think for a moment of a baker who has a very precious kind of leaven; he uses part of this in baking a large loaf; but he so arranges matters, 
by a curious contrivance, that part of the original leaven is not mixed up with the dough, but is carried on unaltered within the loaf, carefully preserved for use in another baking. Nature is the baker, the loaf is a body, the leaven is the germplasm, and each baking is a generation.

Picture the long runner of a strawberry, bearing rooted, flowering plants at intervals: the runner may represent the continuous line of germ-cells, the flowering plants are the individuals, and the relation between them is the relation of genetic continuity, which we call heredity.

It will be obvious that this concept of germinal continuity is very different from Darwin's provisional hypothesis of pangenesis, according to which the germ-cells have their peculiar virtue of reproducing like from like because they become the storehouses of representative gemmules liberated from the various organs of the body. Although the hypothesis did not at the time obtain favour and is less acceptable now than ever, it is interesting to note, as Prof. Strasburger points out, that it included the favourite modern idea of invisible units as the carriers of particular hereditary characters.

(5) Critical Attitude in regard to Various Conclusions.-Another change is seen in the critical attitude which is now taken up in regard to various sets of facts, or alleged facts, relating to inheritance, which were once accepted without question. Thus Darwin said a good deal about reversion; but many phenomena labelled " reversion" have received a different interpretation, and some of the leading authorities on heredity have ceased to use the term. It is difficult to find a scientific worker who believes in what many 
practical men put money on-the influence of a previous sire on offspring subsequently borne by the same mother to a different father. More serious, however, is the wide-spread scepticism as to the transmission of individually acquired characters or modifications.

(6) Mendelism.-But the greatest change that has come about since Darwin's day is the most recent $^{1}$ one-associated with the work of Mendel. We shall devote some attention to this at a later stage in our exposition, but it may be noted, in the meantime, that Mendelian experiment has afforded evidence that an inheritance often consists, in part at least, of well-defined, nonblending " unit characters." "By a unit character in the sense of Mendel's law we mean any quality or part of an organism, or assemblage of qualities or parts, which can be shown to be transmitted in heredity as a whole and independently of other qualities or parts." 2 The inheritance in a fertilised egg-cell consists of an assemblage of distinct ingredients in duplicate, contributed from the father and from the mother. If both the germcells (egg-cell and sperm-cell) bring in a similar ingredient when they unite in fertilisation, then all the germ-cells of the offspring will have it; if neither bring it in, then none of the germ-cells of the offspring will have it. Two blue-eyed parents (without pigment in the front of the iris) do not have dark-eyed children. If the

${ }_{1}$ We must say recent, for although Mendel died two years after Darwin and published his great discovery in 1865, his work was lost sight of till 1900, when Correns, Tschermak, and De Vries were independently led to a rediscovery of Mendel's law and to a discovery of his buried memoirs.

2 W. E. Castle, in "Fifty Years of Darwinism" (1909), p. 146. 
ingredient come in from one side and not from the other, then, on an average, in half the resulting germ-cells it will be present, and from half it will be absent. "This last phenomenon, which is called segregation, constitutes the essence of Mendel's discovery." "In this," Mr. Punnett says, "lies the explanation of the facts that hybrids mated together produce a definite proportion of the pure forms, which subsequently breed true without ever giving a hint of their mixed ancestry."

Methods of Studying Heredity.-In studying a difficult problem, such as the weather, there are three possible lines of attack: we may make minute researches, e.g. on the rôle of dust in forming fog; we may make experiments, e.g. on the change of a cloud into rain, or on the effect of tree-planting on climate; or we may collect a multitude of observations of a statistical character, e.g. as to the rainfall in different localities and at different times of year. These are three sound methods, which have been worked with success. They are complementary, not opposed.

Similarly, we may attack the problems of heredity by the microscopical study of the germcells in which life is continued from generation to generation, by breeding experiments, and by the statistical study of the measurable characters of successive generations. ${ }^{2}$ These three different methods of attacking the problems of heredity

1 W. Bateson, "The Methods and Scope of Genetics " (Cambridge, 1908), p. 15.

2 It is of interest to note that Sir Francis Galton, who may be taken as the representative of the statistical study, and Gregor Mendel, who was the pioneer of the experimental study, were born in the same year (1822). 
seem to be equally valid, and though the generalisations reached along the different lines do not at present cohere in a harmonious body of doctrine, there is no reason to doubt that this will gradually develop. Let us illustrate some of the results attained along the three lines.

Microscopical Study of the Germ-cells.Most plants and animals are built up of cells and start in life as fertilised egg-cells, and it was in a fertilised egg-cell that our own natural inheritance consisted. A few exceptions may be made-e.g. for bananas, which have no longer any seeds; for potatoes, which are multiplied by cutting; for the drone-bees and summer greenflies, which have mothers but no fathers; and for the simple, single-celled organisms which are themselves comparable to eggs and sperms; but the exceptions are trivial compared with the vast majority of living creatures of which it is certain that each individual life begins as a fertilised egg-cell-the result of the intimate and orderly union of a spermatozoon and an ovum.

We get a very misleading idea of the ovum, or egg-cell, when we think, as we always do at first, of birds' eggs. For in these familiar objects the true egg-cell has been dilated by an enormous quantity of nutritive yolk, on the top of which a minute drop of nucleated living matter lies like an inverted watch-glass. Most ova are very minute cells, often invisible to the naked eye. The spermatozoon, or male element, which fertilises the egg, is smaller still; it is often only $\frac{1}{100000}$ th of the ovum's size. In a way that we cannot picture each of the germ-cells (or gametes) carries a complete set of hereditary characters. All theory 
apart, it is by the minute germ-cells that the secret of life and the character of each kind of living creature are sustained from generation to generation. Within every cell in the body of an organism there is usually a nucleus, and within the nucleus a number-a definite number-of readily stainable rods, or loops, or grains called chromosomes. Each kind of living creature has a definite number; thus, there are thirty-two in man and in the cockroach, twenty-four in mouse and in lily, twelve in the grasshopper, and two in a species of threadworm. There is no doubt that these stainable bodies, or chromosomes (including less visible bodies associated with them), are very important. There are many facts pointing to the conclusion that they are bearers (not perhaps the exclusive bearers) of specifically different materials which, in appropriate conditions, will develop into particular heritable qualities. One of the leaders of experimental zoology, Dr. Przribram, sums up a number of remarkable investigations when he says: "Substances or parts can be actually demonstrated in the ovum, the removal of which conditions the absence of definite organs or parts in the embryo." Now, while the immature germ-cells have the same number of chromosomes as the cells of the body have, the mature germ-cells have half the normal number. If 8 be the normal number, the ripe ovum has 4, and the fully formed spermatozoon has 4, so that when the ovum is fertilised the normal number is restored. In a remarkable way, by a kind of cell-division which occurs only in the maturing germ-cells, the number of chromosomes is always reduced by a halfexcept, indeed, in certain cases of parthenogenesis. 
In this reduction, which means in the case of the egg the absolute rejection of half of the chromosomes (which are carried off by the first polar body and come to nothing), we see an opportunity for permutations and combinations among the items of the inheritance, e.g. for the dropping out of a character altogether.

Not less important is the visibly demonstrable fact that sperm and ovum contribute the same number of chromosomes (except in certain cases where half of the spermatozoa have an extra chromosome), and that, when the fertilised eggcell divides, each daughter-cell receives the normal number of chromosomes, half of maternal origin and half of paternal origin. This has been followed for several divisions, so that, if the chromosomes are inheritance-bearers, we have ocular demonstration of the truth of the prophetic statement which Huxley made in 1878: "It is conceivable, and indeed probable, that every part of the adult contains molecules derived both from the male and from the female parent; and that, regarded as a mass of molecules, the entire organism may be compared to a web of which the warp is derived from the female and the woof from the male."

Statistical Study: Filial Regression.Darwin's illustrious cousin, Sir Francis Galton, has been the leader in the statistical study of inheritance. He has shown the value of collecting statistics as to the resemblances and differences in successive generations, e.g. as regards stature, colour of eyes, and intellectual ability, and he has reached several general inductions which express the inherent orderliness obtaining even 
in a domain where occurrences seem as capricious as those of weather.

It has often been remarked that the children of extraordinarily gifted parents are sometimes very ordinary individuals, and that the children of under-average parents sometimes turn out surprisingly well, both physically and mentally. Every one who has looked into the facts of inheritance in greater detail, and has compared the average of qualities in successive generations, has noticed, in a general way, that there is a tendency to sustain the same average level from generation to generation. Even the older inquirers, like Lucas, called attention to the fact that extraordinary qualities in families tend to wane away, as if there were some mysterious succession-tax levied on marked deviations from the average, whether in the way of excellence or of defect. But we owe to Galton's careful statistical work the generalisation known as the Law of Filial Regression, which has replaced a vague impression by a definite formula. He has defined and measured the tendency towards mediocrity, the tendency to approximate to the mean, or average, of the stock. We must notice, at the outset, that this Filial Regression has nothing to do with reversion or with degeneration, that it works upwards as well as downwards, forwards as well as backwards.

The data which Galton utilised were chiefly the records of family faculties, obtained from about one hundred and fifty families, and dealing especially with stature, eye-colour, temper, artistic faculty, and some forms of disease. These were supplemented by measurements at Galton's anthro- 
pometric laboratory, and by observations on sweet-peas, and to some extent on moths.

Most trustworthy, however, were the data procured in regard to stature, which, as Galton points out, is a quality with many advantages as a subject of investigation. It is nearly constant during mature life, it is readily and frequently measured with accuracy, and it does not seem to be of appreciable moment in sexual selection. Its variability, though small, is normal ; that is to say, it is expressible in the normal curve of the frequency of error.

As the subject is by no means easy to those unaccustomed to statistical inquiry, and as we cannot, within our limits, explain the methods, it may be most profitable to give a few illustrative quotations from Galton's " Natural Inheritance" (1889).

"If the word 'peculiarity' be used to signify the difference between the amount of any faculty possessed by a man and the average of that possessed by the population at large, then the law of regression may be described as follows. Each peculiarity in a man is shared by his kinsmen, but on the average in a less degree. It is reduced to a definite fraction of its amount, quite independently of what its amount might be. The fraction differs in different orders of kinship, becoming smaller as they are more remote" (p. 194).

"However paradoxical it may appear at first sight, it is theoretically a necessary fact, and one that is clearly confirmed by observation, that the stature of the adult offspring must on the whole be more mediocre than the stature of their parents; 
that is to say, more near to the mean or mid of the general population" (p. 95).

"The law of regression tells heavily against the full hereditary transmission of any gift. Only a few out of many children would be likely to differ from mediocrity so widely as their mid-parents, ${ }^{1}$ and still fewer would differ as widely as the more exceptional of the two parents. The more bountifully a parent is gifted by nature, the more rare will be his good fortune if he begets a son who is as richly endowed as himself, and still more so if he has a son who is endowed yet more largely. But the law is even-handed; it levies an equal succession-tax on the transmission of badness as of goodness. If it discourages the extravagant hopes of a gifted parent that his children will inherit all his powers, it no less discountenances extravagant fears that they will inherit all his weakness and disease" (p. 106).

"It must be clearly understood that there is nothing in these statements to invalidate the general doctrine that the children of a gifted pair are much more likely to be gifted than the children of a mediocre pair. They merely express the fact that the ablest of all the children of a few gifted pairs is not likely to be as gifted as the ablest of all the children of a very great many mediocre pairs" (p. 106).

Nor must the fact of regression be supposed to affect the general value of a good stock or the general disadvantage of a bad one. Two gifted members of a poor stock may be personally equiva-

1 The mid-parent is a statistical fiction, with a stature half that of the two parents when allowance is made for the average difference of stature in the two sexes. 
lent to two ordinary members of a good stock, but " the children of the former will tend to regress ; those of the latter will not" (p. 198).

Let us give a concrete illustration from Prof. Karl Pearson's "Grammar of Science" (1900, p. 454): "Fathers of a given height have not sons all of a given height, but an array of sons of a mean height different from that of the father and nearer to the mean height of sons in general. Thus, take fathers of stature 72 inches, the mean height of their sons is $70.8 \mathrm{in}$., or we have a regression towards the mean of the general population. On the other hand, fathers with a mean height of 66 in. give a group of sons of mean height $68.3 \mathrm{in}$., or they have progressed towards the mean of the general population of sons. The father with a great excess of the character contributes sons with an excess, but a less excess of it; the father with a great defect of the character contributes sons with a defect, but less defect of it. The general result is a sensible stability of type and variation from generation to generation."

There seems no reason to doubt the general occurrence of regression towards mediocrity, though the law requires modification in regard to characters which are subject to keen selection, either natural or sexual, and though it does not apply to sharply defined "unit characters" which do not blend.

Galton's Law of Ancestral Inheritance.It is necessary, however, to ask what this statistically established fact of filial regression really means biologically.

In all ordinary cases of reproduction the offspring has a strictly dual or bi-parental inheritance. 
Whatever the inheritance may be in its expressionwhether it show a blend or takes after one side of the house-it is made up, to begin with, of equal contributions from the two parents. Obviously, however, if the concept of the continuity of the germplasm be correct, the contribution from the father is made up of contributions from his two parents, and the contribution from the mother is made up of contributions from her two parents. And so on backwards. Thus we reach the idea, to be corrected in cases where Mendelian inheritance has been proved for particular characters, that an individual inheritance is a mosaic of ancestral contributions. Incidental corroborations of this fruitful idea are familiar to all-e.g. in the reexpression of peculiarities which were characteristic of, say, a grandfather or a great-grandmother.

But we owe to Galton's careful statistical work, as to stature and other qualities in man, and as to coat-colour in Basset hounds, a generalisation which formulates the share which the various ancestors have, on an average, in the inheritance of any individual organism. This Law of Ancestral Inheritance is as follows: "The two parents between them contribute, on the average, one-half of each inherited faculty, each of them contributing one-quarter of it. The four grandparents contribute between them one-quarter, or each of them one-sixteenth; and so on, the sum of the series $\frac{1}{2}+\frac{1}{4}+\frac{1}{8}+\frac{1}{16}+\ldots$, being equal to 1 , as it should be. It is a property of this infinite series that each term is equal to the sum of all those that follow: thus $\frac{1}{2}=\frac{1}{4}+\frac{1}{8}+\frac{1}{16}+\ldots$, $\frac{1}{4}=\frac{1}{8}+\frac{1}{16}+\ldots$, and so on. The prepotencies or subpotencies of particular ancestors, in 
any given pedigree, are eliminated by a law that deals only with average contributions, and the varying prepotencies of sex in respect to different qualities are also presumably eliminated." Thus an inheritance is not merely dual, but through the parents it is multiple, and the average contributions made by grand-parents, great-grandparents, etc., are definite, and diminish in a precise ratio according to the remoteness of the ancestors.

Experimental Study.-Perhaps we may most profitably illustrate the experimental study of heredity by asking what the possible results are of pairing two hypothetical organisms. Although prediction as to the result of any individual pairing is apt to be falsified (except in clear cases of Mendelian inheritance), there are some wellknown alternatives of expectation.

(1) Pairing of Similar Pure-bred Forms.-Let us begin with the offspring of similar pure-bred organisms. When similar forms are bred together for several generations a certain uniformity of type is likely to result. If by selection the most similar are mated together, while the least similar are persistently removed from the stock, and if there is also some measure of inbreeding, then there is likely to be more or less constant uniformity of type. These " pure-bred" organisms produce others like themselves, and we suppose this to mean that the hereditary items in the ovum have not only their counterpart, but their equivalent, among the hereditary items in the spermatozoon. This, then, is one of the modes of inheritance-that the offspring closely resemble the parents and one another. The variability is restricted within a small range.

(2) Blending.-Passing from the mating of 
similar pure-bred organisms to other cases, we note, as a frequent occurrence, that the offspring is a combination of the paternal and maternal characteristics in such a thoroughgoing way that the result may be described as an intimate blend. In a cross between the long-eared lop-rabbit and a shorteared breed, Castle found that forms with ears of intermediate length are produced, and that these intermediates breed true. The colour of the skin in mankind seems to blend when white and black races are crossed. Many plant hybrids are precisely intermediate between the two parents.

(3) Particulate Inheritance.-The offspring often show what may be called a coarse-grained or non-blended combination of the paternal and maternal characteristics, the former appearing in one part of the body, the latter in another part, as when a light-coloured horse and a dark-coloured mare have a piebald foal, or when a sheep-dog has an eye like its father on one side and an eye like its mother on the other side. This is often described as particulate inheritance.

(4) Exclusive Inheritance.-It often happens that the offspring takes wholly after one of its parents, or wholly as regards particular organs, and extreme forms of this are spoken of as exclusive inheritance. The inheritance of eye-colour in mankind belongs to this type. Although the inheritance is dual, it seems as if only one set of the heritable characters found expression-at least as regards particular organs. The more pure-bred parent is the more likely to be prepotent in the inheritance. This exclusive inheritance may be the first step in a clear Mendelian case, which we shall consider later. 
(5) Reversion.-Another mode of inheritance - known as Reversion-is seen when the offspring exhibits features which were not expressed in its immediate ancestry, but were characteristic of more remote ancestry, as when crossing different races of pigeons, which have been breeding true, results in the production of the ancestral rockdove type. Professor Cossart Ewart crossed an "Owl " with an "Archangel" and obtained a hybrid more like the former than the latter. $\mathrm{He}$ crossed this with a prepotent white fantail and obtained two pigeons closely resembling the wild rock-dove type. Darwin laid stress on such reversionary Blue Rocks which occur when widely differing breeds are crossed and the hybrids are bred together, but some recent experiments, e.g. those of Staples-Browne, suggest that there may be a Mendelian interpretation even of Darwin's classic cases of reversion. The case of rabbits is very suggestive. When rabbits of different colours are turned loose and breed together, their descendants tend to be eventually all grey. Darwin regarded this as a reversion, and it may still be described as reversionary; but it is not due to the reassertion of long latent grey colouring. The return to grey is due, as the Mendelian experiments show, to the recombination of at least eight colour-ingredients that go to the make-up of wild greyness. Man has sifted out all the various colours from the complex coloration of the wild stock, and when the long-separated items are brought together again by unrestricted interbreeding there is, naturally enough, a reconstruction of the original grey colour.

(6) New Departures.-Just as we began by 
noting that the offspring of carefully pure-bred types might be almost replicas of the parents, so we must notice the opposite extreme, where the offspring represent something quite new-a novel position of organic equilibrium-a "freak," or " sport," or " mutation," or " discontinuous variation." That these new departures have sometimes formed the beginning of a new domesticated breed or cultivated variety is well known; and it is possible that species in nature may sometimes have arisen in a similar way.

(7) Mendelian Inheritance.-In typical cases of Mendelian inheritance we have to do with the pairing of two pure-bred types which differ from one another in respect of one or more unit characters, which may be obvious qualities, such as colour and markings, or more subtle qualities, such as the loaf-producing "strength" of wheat, its susceptibility or immunity in respect to rust, the broodiness or non-broodiness of poultry, the horned or hornless state of the head in cattle.

The result of the crossing is that the "hybrid" progeny all resemble one parent in respect of the contrasted characters. There are no intermediates, for Mendelian characters do not blend. The offspring of grey and white mice are all grey; the offspring of giant and dwarf peas are all tall; and so on. It is usual to speak of the character that persists and is expressed as the dominant character, while that which remains unexpressed or latent is called recessive.

But when the "hybrids" are inbred, the next generation shows a reappearance of the original parental types both dominant and recessive- 
both breeding true-and a number of forms, usually like pure dominants, which, when inbred, again produce "pure dominants," "pure recessives," and "impure dominants" like themselves. In typical cases, where attention is paid to one pair of contrasted characters, the proportions of the "hybrids" always approximate to the formula-1 pure dominant : 2 impure dominants : 1 pure recessive.

This may be expressed in a simple schema:

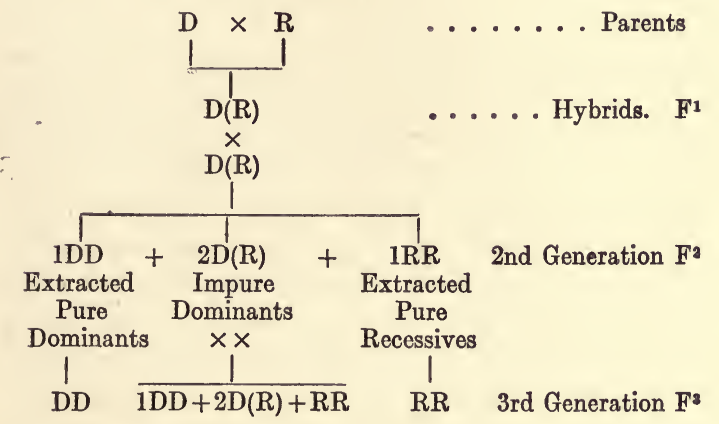

Mendel explained his results by the ingeniously simple hypothesis of segregation. He supposed that the germ-cells of the hybrids segregated into two contingents, one half bearing the dominant character and one half bearing the recessive character. If fertilisations follow the laws of chance the second generation should theoretically show the proportions which actually occur. When there are two pairs of contrasted charactersfor instance, when a tall yellow-seeded (Dd) pea is crossed with a dwarf green-seeded one $(\mathrm{Rr})$ the offspring are tall yellows $(\mathrm{Dd})$, combining the 
two dominant features; and when these are selffertilised (which is equivalent to inbreeding), out of 16 offspring there are 9 tall yellows (Dd), 3 tall greens (Dr), 3 dwarf yellows (Rd), and one dwarf green $(\mathrm{Rr})$. When a rabbit of the wild grey colour is crossed with an albino, the offspring are all grey, and these, if bred together, give in certain cases 9 greys, 3 blacks, and 4 albinos, which is a slight modification of the ordinary $9: 3: 3,1$ ratio due to the impossibility of distinguishing, by external appearance, between two different kinds of albino.

UNTT Characters.-We do not at present know with certainty how many qualities and parts can be called "unit characters" in the Mendelian sense. The only criterion is the experimental one : can the character be lost, as a whole, in crossbreeding? Prof. W. E. Castle ${ }^{1}$ gives an illustration: "If we cross a black guinea-pig with one which lacks black-say a brown one-we obtain only black offspring; but these bred inter se produce black offspring and brown ones, in the proportion three black to one brown. We thus learn that black is a unit character. It was contributed by one parent to the cross, but not by the other, and transmitted by the cross-bred individual to half its offspring, but not to the other half. This is Mendel's explanation of the 3:1 ratio, now familiar to every biologist.

"But if we cross the same black parent in the foregoing case, not with a brown individual, but with a white one or with a yellow one, we may obtain, not black offspring, but wild-coloured

1 " The Behaviour of Unit Characters in Heredity," in " Fifty Years of Darwinism" (1909), p. 148. 
' agouti' ones, which bred inter se will produce agouti, black, white (or else yellow) young, with perhaps those of other new classes in addition. Such a result as this puzzled Darwin, and would naturally puzzle any one; but in the light of Mendel's law becomes capable of ready explanation. The production of black pigment is a process in which more than one unit character is concerned, the production of a grey coat involves more units still. ... What was unknown to Mendel has been made clear since 1900: that in many cases two or more independent unit characters must be present to produce a single visible effect."

The Case of Andalusian Fowls.-The phenomena of Mendelian inheritance are well illustrated in the case of the Blue Andalusian fowl. We quote Mr. Punnett's account ${ }^{1}$ : "The Andalusian has long been known to possess an inconvenient peculiarity : it will not breed true. It always throws ' wasters' of two sorts : blacks, and whites marked with some black splashes. There are, therefore, three kinds of Andalusians, and consequently six possible types of mating among these three varieties. With regard to the results of these types of mating, careful experiment has brought out the following facts :

Blue $\times$ Blue gives Blacks, Blues, and Whites, in the ratiol :2:1. Blue $\times$ Black , Blacks and Blues in equal numbers.

Blue $\times$ White", Blues and Whites in equal numbers. Black $\times$ Black , Blacks only. White $\times$ White," Whites only. Black $\times$ White ,, Blues only.

1 "Mendelism in Relation to Disease," "Proc, Roy. Soc. Medicine" (March 1908). 
"We are dealing here with a case in which every possible form of mating has been carried out, and some of the results, at first sight, seem paradoxical. Thus, for instance, the blacks always breed true, whatever their ancestry may have been; and the same holds good for the whites. The white that is produced by two blues, themselves the product of mating blue with blue over many generations, breeds as true to whiteness as the white of pure white ancestry. A black is pure for blackness and a white is pure for whiteness, whatever the ancestry of the bird may have been. Again, it seems at first sight incongruous that the mating of black with white should give just twice as many blues as two blues mated together.

"We are dealing with an alternative pair of characters, blackness and whiteness. Every germcell, or gamete, whether ovum or spermatozoon, bears a representative of this pair. But it can bear only one representative, viz. either blackness or whiteness. Hence for this pair of characters there are two, and only two, types of gamete: 'black' gametes and 'white' gametes. When a black gamete meets a black the result is a black bird; when a white meets a white the result is a white bird; but when a white meets a black the resulting zygote ${ }^{1}$ contains the representatives or factors for both blackness and whiteness, and develops into a blue bird. Now we must suppose that the gametic representative of a character, the factor, is an unsplittable entity so far as inheritance is concerned. The zygote, being

1 Gamete is the technical term for a germ-cell, either egg-cell or sperm-cell; zygote is the technical term for the egg-cell after it has been fertilised by the sperm-cell. 
formed by two gametes, must contain two factors. It is a double structure, and, when it comes to form gametes, these single structures are produced by the separation of the two factors present in any zygotic cell. The factors representing the characters are said to segregate from one another in the process. In a zygote produced by the union of similar gametes, the segregation is between like factors, and all the gametes produced are alike. But a zygote which has been formed by two dissimilar gametes, each bearing one of the factors corresponding to a pair of characters, must, on forming gametes, give rise to gametes of two sorts, and must give rise to them in equal numbers. On this simple hypothesis is afforded a ready explanation of the various experimental facts given above.

"A blue hen is producing equal numbers of 'black' and 'white' eggs-let us say $2 n$ of each. To fertilise these eggs are brought large numbers of spermatozoa of the two sorts, black and white, in equal numbers. Every black egg, then, has an equal chance of being fertilised by a black or a white spermatozoon. In the former case it will form a black, and in the latter a blue, bird. From our $2 n$ black eggs we shall obtain $n$ black, and $n$ blue birds; that is to say, the mating of blue with blue must, on the assumption of the purity of the gametes, give black, blue, and white in the ratio $1: 2: 1 . "$

WaLtzing Mice.-Let us take another illustration relating to the quaint Japanese waltzing mice, which waltz round and round in circles and have only one semicircular canal of the ear well developed. When waltzing mice are crossed with 
normal mice all the progeny are normal. The waltzing habit is recessive, the normal is dominant. When the hybrids are inbred the resulting generation consists of normal mice and waltzing mice in the proportion of three dominants to one recessive. The recessives of this generation, when inbred, yield only recessives, for as many generations as one likes to breed them. The dominants are found to be of two kinds: one-third of themcalled pure dominants-when inbred yield only dominants; the other two-thirds-called impure dominants-yield dominants and recessives in the old proportions of $3: 1$.

It is supposed that the hybrids have germ-cells of two kinds, one half bearing the waltzing character, the other the normal character. Each germ-cell is "pure" as regards this character. There are twice as many chances of the unlike combination occurring - that is, of normal and waltzing -as of the like combination occurring-that is, of normal meeting normal, or waltzing waltzing. In other words, the percentage of individuals in the three groups will be what it is: 25 pure normal, 50 impure normal, and 25 pure waltzing.

OcCURRence of Mendelian Inheritance.Mendelian phenomena are known in rats, mice, rabbits, guinea-pigs, poultry, canaries, snails, silkworms, and some other animals ; in peas, beans, stocks, wheat, barley, maize, and some other plants. The characters which illustrate it are such as size, colour, markings, crests, horns, hairiness, peculiar features such as the waltzing habit in mice, and elusive properties, such as broodiness in hens, time of ripening and immunity in wheat. It is doubtful how far Mendelian phenomena 
occur in man. Human eyes may be arranged in two groups: $(a)$ those with brown pigment on the outer as well as on the inner surface of the iris (usually browns and greens); and (b) those without such brown pigment on the outer side, but with some pigment on the inner side (blues and greys). It appears, from the researches of Hurst and of Prof. and Mrs. Davenport, that the first type is dominant and the second recessive. Hurst also gives some evidence that " fiery red" hair behaves as a recessive to brown, and that the musical sense is recessive to the non-musical. The clearest case, as yet, is that peculiar condition of the hands and feet known as brachydactyly, which Farabee and Drinkwater have found to be dominant to the normal condition. Of great interest also is $\mathrm{Mr}$. Nettleship's account of the descendants of one Jean Nougaret (born 1637) who was afflicted with night blindness - a condition apparently due to loss of the visual purple. There are records of over 2,000 individuals; and the night blindness is dominantover the normal. During two and a half centuries no normal member of the family who has married another normal, whether related or not, has ever transmitted the disease.

Practical Importance of Mendelism.-The work of the Mendelian school of experimenters since 1900 is full of achievement and promise, and no naturalist can help envying those who have been able to share in it, all the more that their discoveries are full of practical as well as theoretical import. Prof. Bateson writes: "If we want to raise mangels that will not run to seed, or to breed a cow that will give more milk in less time, or milk with more butter and less water, we can turn to 
genetics with every hope that something can be done in these laudable directions. But here I would plead what I cannot but regard as a higher usefulness in our work. Genetic inquiry aims at providing knowledge that may bring, and I think will bring, certainty into a region of human affairs and concepts which might have been supposed reserved for ages to be the domain of the vísionary." He alludes to liability to particular disease, addiction to a particular vice, and so on, and says: "As regards the more tangible of these physical and mental characteristics there can be little doubt that, before many years have passed, the laws of their transmission will be expressible in simple formulæ." 1

Much Progress, but Great Uncertainty.Especially through the work of the Mendelians great strides have been made in the last ten years in our-knowledge of the laws of inheritance. By breeding two pairs of rabbits which, to the ordinary eye, seem identical, an experimenter like Mr. Hurst acquires a knowledge of their inherent germinal qualities (or gametic constitution), and he can successfully predict the difference between the results of mating the two pairs. The statisticians can predict average results in 1,000 offspring; the Mendelian breeder can predict the distribution of certain characters in a litter. In spite of this progress, and partly because of it, we are confronted with an array of unanswered questions concerning this most fascinating of problems. In what cases are the facts of inheritance clearly Mendelian, and how do these cases differ from others that seem as clearly non-Mendelian? Is it the case

${ }^{1}$ W. Bateson, "The Methods and Scope of Genetics" (1908). 
that particular ancestral qualities may be latent for more than two generations, and then re-assert themselves as reversions? What adjustment of statement, if any, will bring Galton's Law (a statistical conclusion) and Mendel's Law (an experimental conclusion) into harmony? What is the nature of the character which we call " maleness" or "femaleness," and is there any law which will formulate its distribution in the progeny of a pair ? These are some of the urgent questions towards the answering of which facts are accumulating every month.

The Transmission of Acquired Characters.Let us turn, however, for a little to the long-drawnout controversy as to the possible transmission of " acquired characters," or somatic modifications. It may be said that the disputants are now agreed as to the precise point at issue, and perhaps it may also be said that neither the yeas nor the nays ring out so confidently as they did ten years ago. Let us state the case. Members of the same species often differ from one another, and these differences can be measured and registered under the title of " observed differences," which commits one to no theory. Many of these differences depend on age and sex, and these can be readily recognised and allowed for. Others depend on peculiarities of " nurture," in the wide sense; that is, they are the direct results of peculiarities in surrounding influences or in function. Such changes in plant or animal are impressed from without, they are " exogenous" in origin, they are acquired not inborn, and they are technically called "somatic modifications," or " acquired characters." They may be defined as structural changes in the body of 
an individual directly induced by changes in function or in environment, which transcend the limit of organic elasticity and thus persist after the inducing conditions have ceased to operate. Thus fattening and sumburning are modifications, though the predisposition to them may be inborn; the formation of a callosity as the result of pressure and the reduction of a muscle by prolonged disuse are modifications, though it does not, of course, follow that callosities and reduced muscles may not come aboutin a quite different way, namely, by a germinal variation. Now, when we subtract from the total of observed differences between members of the same species all that can be described as modifications, we find a large remainder which we must define off as inborn or germinal variations. We cannot causally relate them to any peculiarities in the organism's habits or surroundings, they are often distinct at birth or hinted at before birth, they are rarely alike even among forms whose conditions of life seem absolutely uniform. They are endogenous, not exogenous in origin ; they are results of changes in the germinal material; they are born, not made ; and they are more or less transmissible, though they are not by any means always transmitted." They form-at least some of them form-the raw material of organic evolution, whereas modifications, as defined, are probably not of direct importance in evolution, since we have no secure evidence that they are ever transmitted as such, or in any representative degree.

1 Darwin assumed that little fluctuations are more certainly transmissible than marked idiosyncrasies, but all that we are quite certain of is that a number of variations, both large and small, are definitely transmissible. 
There is no doubt that modifications are very common, that they are of much individual importance, that they may have an indirect influence through the body on the offspring (especially in the case of mammalian mothers), that they may have an indirect importance in evolution in several ways, but the precise point at issue is this: Does a structural change in a part of the body, induced by use or disuse, or by change in surroundings and nurture generally, ever influence the germ-plasm in the reproductive organs in such a specific or representative way that the offspring will thereby exhibit the same modification that the parent acquired, or even a tendency towards it? We do not know of any clear case which would at present warrant the assertion that a somatic modification is ever transmitted from parent to offspring.

In regard to this important question, let us try to clear the ground by noting a few of the common misunderstandings. ${ }^{1}$

I. How can there be progressive evolution if acquired characters are not entailed? By the accumulation of germinal variations, such as those which have separated the higher from the lower races of mankind. Yet Herbert Spencer actually said, "Either there has been inheritance of acquired characters, or there has been no evolution." In 1796 the speed of the English trotter was a mile in 2 mins. 37 secs. ; it is now a mile in 2 mins. 10 secs., or less; but that is the result of the selection of inborn variations, not of the transmission of acquired characters.

II. Many facts in nature are readily interpretable

1 See "Heredity," by J. Arthur Thomson. (Murray. London 1908.) 
on the theory that the results of use and disuse and of environmental change are, as such, transmissible. The black skin may be interpreted as due to the sun. The callosities on the knees of the wart-hog may be interpreted as due to pressure on the ground. The twelve hours' sleeping and waking of many acacias may be interpreted as a functional adaptation which has become hereditary. But the interpretations may be erroneous.

III. Many beg the question by starting with a character, like short-sightedness or gout, which has not been proved to be a modification. First catch your modification. The little toe is said to be dwindling in consequence of wearing tight boots ; but we are not sure that there is dwindling, and if there is, we have no experimental reason for blaming the boots.

IV. The reappearance of a modification in successive generations is often mistaken for transmission. It may be hammered on to each successive generation. Nägeli put Alpine plants in rich garden soil and they became very different, and their progeny likewise; but transference to poor soil brought back the Alpine characters, which showed that the new characters had not taken any hereditary grip.

V. Infection of the offspring by the parent before birth has nothing to do with inheritance in the true sense.

VI. Transmission in unicellular organisms is not to the point, for, as they have no "body," the concept of somatic modifications does not apply to them.

VII. Changes in the germ-cells along with changes in the body, where there are deeply 
saturating influences such as poisons, are not cogent.

VIII. Modifications may have secondary effects on the germ-cells and the offspring, e.g. in the way of bad nutrition, but unless the offspring show peculiarities in the same direction as the original modifications, we have no data bearing precisely on the question at issue.

A belief in the inheritance of modifications was perhaps expressed in the old proverb, " The fathers have eaten sour grapes, and the children's teeth are set on edge "-a proverb which Ezekiel, with such solemnity, said was not any more to be used in Israel. Now if "setting on edge" was a structural modification, and if the children's teeth were "set on edge" as their fathers' had been before them, there would be a presumption in favour of the transmission of this acquired character, though it would be still necessary to inquire carefully whether the children had not been in the vineyard too. If, as Romanes said, the children were born with wry necks, we should have to deal with the inheritance of an indirect result of the parents' vagaries of appetite, and not with any direct representation in inheritance of the particular modification produced in the paternal dentition.

IX. Finally, there is no use appealing to data from fewer than three generations. Sheep transported to a cold country get longer fleece, their offspring have still longer fleece; but this is not to the point, since the offspring were subjected to the modifying influences from birth. We wish to know whether the third generation is more markedly modified than the second.

Disease.-As a particular case we may take 
the important question of the transmissibility of acquired disease. When the question is carefully considered, it seems possible to distinguish between (1) abnormal or deranged processes which have their roots in germinal peculiarities or defects (variations), and (2) abnormal or deranged processes which have been directly induced in the body by acquired modifications, i.e. as the results of unnatural surroundings or habits, including the intrusion of parasites. There is very little evidence to suggest that this second kind of disease is heritable as such, though the indirect effects may influence the offspring. When we go further and come to understand that prenatal infection is not inheritance, that inheritance of a predisposition to a disease is not inheritance of the disease, that the general weakening of the offspring through disease in the parent is a very different matter from the transmission of a specific disease, we are almost irresistibly led to the conclusion that in the sense in which the word " inherited " is used in biology, there are no inherited diseases. What does seem to be inherited, however, is a defectiveness or degeneracy of the germplasm which finds one expression in the parent and another in the offspring.

Facts aNd Possibilities.-The evidence in support of the transmission of acquired characters is either very anecdotal or very uncritical, and, until some cogent cases are forthcoming, the thoroughgoing scepticism which Weismann expressed many years ago remains justified.

Besides the unsatisfactory nature of the evidence, we have to admit the difficulty of imagining any means whereby a modification of a particular 
organ of the body can react upon the germ-cells in a manner so specific that these can, when they develop, reproduce the particular parental modification or any approach to it. Darwin and Spencer both faced this difficulty, and tried to meet it; but no one now accepts their provisional hypotheses. It is true that a mechanism may exist though it remains unknown; it is true that important influences, mysterious in their nexus, pass from reproductive organs to body; but we should not have recourse to difficult hypotheses before we are sure that there is any need for them. There is no doubt that the germ-plasm may be influenced by the blood, but this is different from admitting the transmission of a particular acquired character.

In a well-known case, where the evidence points, according to some, to the heritability of an artificially induced epileptic condition, it has been suggested that the epilepsy produces a toxin which passes to the germ-cells so that the offspring are epileptically affected. Now if we dared to suppose that a deeply saturating modification produces a representative chemical substance analogous to a toxin, and that this passes to the germ-cells, the hereditary reappearance of a modification would be more conceivable.

There are many who think that, sooner or later, there must be a return to Darwin's idea of pangenesis - of specific substances passing from body to germ-cells. The study of hormones is a line of investigation that is of much interest in this connection. "Hormones" are specific substances produced by cells, and passed into the bloodstream to play an important part in stimulating 
or controlling developmental and metabolic processes. Injection of extracts of thyroid has usually a beneficial effect in reducing goitre. Injection of extracts of fotus has an effect on the mammary glands. Injection of testicular extract causes the temporary development of a cock's comb on a hen. There are enough of facts of this kind to make us chary of dogmatism in regard to the possibility of an influence passing from a modification of the body to the germ-cells thereof. As Prof. E. B. Wilson says: "Let us admit freely that such an interaction as Darwin assumed may be a real and potent factor in heredity, though it gives us no hint of its existence in the visible apparatus of the cell. In the present defective state of our knowledge we may well grant that there may be many a thing between germ-cell and body that is not yet dreamed of in our biological philosophy." 1

A Striking CASE.-Kammerer's experiments on salamanders afford the most remarkable piece of evidence as yet adduced in support of the thesis that acquired characters may be transmitted.

(a) The common yellow and black-spotted salamander (Salamandra maculosa) is either viviparous, producing a large number of larvæ 25-30 mm. in length with four limbs and short gills, or ovo-viviparous, laying large eggs which hatch out into similar larvæ $23-25 \mathrm{~mm}$. in length. After a few months of larval life in the water, they undergo metamorphosis into land-salamanders 45-56 mm. in length.

(b) The black Alpine Salamander (Salamandra

1 "The Cell in Relation to Heredity and Evolution," in "Fifty Years of Darwinism" (1909), p. 113. 
atra) produces at birth two fully formed terrestrial young 38-40 mm. in length.

(c) Kammerer kept S. maculosa in the cold, and got it, after a few pregnancies, to produce only two young ones, as in $S$. atra.

(d) He kept $S$. atra in a warm place with plenty of water, and got it to produce 3-9 aquatic larvæ, thus approaching the condition in $S$. maculosa.

(e) The offspring of the Salamanders thus treated $(c$ and $d)$, became sexually mature when three and a half years old in conditions normal to S. maculosa. The offspring of (c) gave birth (1) to very advanced larvæ, $45 \mathrm{~mm}$. long with much-reduced gills, metamorphosing several days after, or moderately advanced aquatic larvæ $40 \mathrm{~mm}$. long, with large gills; or (2) to small larvæ, $20 \mathrm{~mm}$. long, with rudimentary gills, laid on land, and metamorphosing after four weeks into salamanders $29 \mathrm{~mm}$. long. Thus there was a partial persistence of a modified mode of reproduction in the absence of the modifying conditions.

$(f)$ The offspring of $(d)$ bore in the water 3-5 larvæ, $33-40 \mathrm{~mm}$. or $21-23 \mathrm{~mm}$. in length, light in colour, and possessing gills. Thus there was an augmentation of the parental modification (d) in conditions which resembled those of the original experiment.

The difficulties in regard to this very interesting set of experiments are: (1) they do not deal with a structural modification; (2) it is possible that the experimental conditions acted directly on the germ-cells in $(c)$ and $(d)$; (3) there was some measure of artificiality in the conditions under which the second generation developed, 
which may have disturbed the normal routine of reproduction.

Logical Position of the Question.-Let us notice the logical position of the question. There are two possible lines of argument: $(a)$ by experiment, and (b) by interpretation. (a) As to $e x-$ periment, it is plain that hundreds of failures to prove the transmission do not demonstrate its impossibility. They only show that it is not usual. One good case experimentally proved would show that the transmission is possible. The best case we know is Kammerer's, and it does not seem cogent. Perhaps better cases will become known. The Lamarckian does not, of course, say that every change of conditions will produce appreciable hereditary effects in a few generations, or that any particular change of conditions chosen more or less arbitrarily for experimental purposes will produce recognisable results in the following generation. But do we know of any clear case of even a faint trace of a well-defined structural modification being transmitted? (b) As to the second method, that of the interpretation of facts, it cannot be conclusive either, since each side has to prove a negative in order to establish its case. The Neo-Lamarckians have to show that the phenomena they adduce as illustrations of modification-inheritance cannot be interpreted as the results of selection operating on germinal variations. In order to do this to the satisfaction of the other side, the Neo-Lamarckians must prove that the characters in question are outside the scope of natural selection, that they are non-utilitarian and not correlated with any useful characters-a manifestly difficult task. 
The Neo-Darwinians, on the other hand, have to prove that the phenomena in question cannot be the results of modification-inheritance. And this is, in most cases, impossible. Thus we seem to reach a logical dead-lock. What we need are more facts.

CAses Where the Theory of ModificationINHERITANCE IS INAPPLICABLE.- It is true, however, that there are certain characters of particular organisms in regard to which it may be said with some security that they could not have arisen by the inheritance of acquired modifications. Thus many insects, and the like, have adaptive characters in their cuticular structures-knobs for crushing, saws suited for cutting, gimlets suited for boring, and so on. But these cuticular structures are non-cellular, non-living parts of the external investment of the body; they are made and remade (after moulting) by the underlying, living skin. How, then, can they be interpreted in terms of modification-inheritance? The matter becomes even more difficult when we consider cases in which the adaptiveness is in the colour or markings of these inert cuticular parts. Weismann has argued that, since there are some adaptive characters which cannot be interpreted in terms of modification-inheritance, this hypothetical factor need not be assumed in attempting to interpret the origin of other adaptations, similar to the former, except that the factor in question is not by the nature of the case apparently excluded from having any connection with them.

But it cannot be said that this application of the "law of parsimony" is altogether successful. It may recoil on those who use it. It might be 
argued that there are some adaptive characters which cannot be readily interpreted in terms of natural selection (as is implied in the appeal of some Neo-Darwinians to "intra-selection," " germinal selection," and so on), and that therefore natural selection cannot be regarded as a generally acting factor. Moreover, the Neo-Lamarckian is at liberty to reply that he does not regard the modification-inheritance theory as applicable to all possible cases.

Importance of Environment and Function Remains.-Although bodily changes due to changes in environment or in function may not be transmissible, the importance of these influences remains. (1) An inheritance cannot be realised without an environment; any more than a man whose legacy was a cheque could make much of it without a bank. (2) Changes in environment and funotion, saturating through the body, may stimulate the variability of the germ-plasm. This may be the cause of mutation. (3) Living creatures are in many cases very plastic, and their modifications are often of great individual importance, and may even preserve the life. (4) The secondary effects of modifications may reach and influence the germ-cells. (5) Every one admits that the state of the maternal constitution is very important in all cases where there is an intimate connection between the mother and the unborn young.

Selection and Stimulus.-In two other ways changes in the conditions of life are of great importance : they form part of the mechanism of selection, whereby the relatively less fit variants are quickly or slowly, roughly or gently, eliminated, and they act as a stimulus to the intrinsic self- 
assertiveness and "endeavour after well-being" which characterise living creatures. We must advance beyond the conventional view that the environment is like a net closing in upon passive victims, which can only escape if they have been fitted by germinal variation (or acquired modification) to pass through some of the meshes; we must recognise, as a fact of life, what Lamarck and many others have discerned, that organisms actively assert themselves against this closing net, and by active endeavour (also, of course, a variational character when traced back) may win their way through. At certain levels every one is actively on the outlook for "a niche of organic opportunity." In his " Luck or Cunning ?" Mr. Samuel Butler asked, "Do animals and plants grow into conformity with their surroundings because they and their fathers take pains, or because their uncles and aunts go away?" The accurate answer is that the question is wrongly put, for even those who most believe in the negative importance of uncles and aunts going away will be willing to admit, likewise, the positive importance of "taking pains." A rehabilitation of the Lamarckian position perhaps depends on making clear what the "effort" of the creature amounts to, and what it really means.

INDIRECT Importance OF Modifications.But there is another important consideration, which has been stated independently by Profs. Mark Baldwin, Lloyd Morgan, and H. F. Osborn, namely, that adaptive modifications may act as the fostering nurses of germinal variations in the same direction. We have referred to this elsewhere, but it may give greater completeness to 
our survey if we quote a brief statement of the idea as expounded by Lloyd Morgan ("Habit and Instinct" (1896), p. 319):

"Persistent modification through many generations, though not transmitted to the germ, nevertheless affords the opportunity for germinal variation of like nature.

"Suppose that a group of plastic organisms is placed under new conditions. Those whose innate plasticity is equal to the occasion are modified and survive. Those whose plasticity is not equal to the occasion are eliminated. . . . Such modification takes place generation after generation, but, as such, is not inherited. ... But any congenital variations similar in direction to these modifications will tend to support them and to favour the organism in which they occur. Thus will arise a congenital predisposition to the modifications in question.

"The plasticity still continuing, the modifications become yet further adaptive. Thus plastic modification leads, and germinal variation follows ; the one paves the way for the other.

"The modification, as such, is not inherited, but is the condition under which congenital variations are favoured and given time to get a hold on the organism, and are thus enabled by degrees to reach the fully adaptive level."

Practical Import of the Question as to the Transmissibility of Acquired Characters.It is scarcely necessary to point out that the longdrawn-out discussion is one of great importance, affecting our whole theory of evolution, and even our everyday conduct. Herbert Spencer went the length of saying that " a right answer to the 
question, whether acquired characters are or are not transmitted, underlies right beliefs, not only in biology and psychology, but also in education, ethics, and politics."

A modification is a definite change in the individual body, due to some change in " nurture." There is no secure evidence that any such individual gain or loss can be transmitted as such, or in any representative degree. How does this affect our estimate of the value of "nurture" ? How should the sceptical or negative answer, which we believe to be the scientific one, affect our practice in regard to education, physical culture, amelioration of function, improvement of environment, and so on ?

(a) Every inheritance requires an appropriate nurture. if it is to realise itself in development. Nurture supplies the liberating stimuli necessary for the full expression of the inheritance. A man's character as well as his physique is a function of "nature" and of "nurture." In the language of the old Parable of the Talents, what is given must be traded with. A boy may be truly enough a chip of the old block, but how far he shows himself such depends on " nurture." The conditions of nurture determine whether the expression of the inheritance is to be full or partial. It need hardly be said that the strength of an (inherited) individuality may be such that it expresses itself almost in the face of inappropriate nurture. History abounds in instances. As Goethe said, man is always achieving the impossible. Semon relates a pretty experiment with young acacias (Albizzia lophantha). They had never been exposed to the normal alternation of day and night, to which their race responds by expanding and closing the 
leaves. Semon exposed them to artificial days and nights of six hours' or twenty-four hours' duration ; but the plants exhibited the twelve-hours' cycle quite unmistakably-just a little altered. After this experiment Semon exposed the plants to continuous darkness or continuous illumination. The twelve-hours' cycle still manifested itself for a time, but gradually became indistinct. Here we see the inherited nature struggling, as it were, against inappropriate nurture.

(b) Although modifications do not seem to be transmitted as such, or in any representative degree, there is no doubt that they or their secondary results may in some cases affect the offspring. This is especially the case in typical mammals, where there is before birth a prolonged (placental) connection between the mother and the unborn young. In such cases the offspring is for a time almost part of the maternal body, and liable to be affected by modifications thereof-e.g. by good or bad nutritive conditions. In other cases, also, it may be that deeply saturating parental modifications, such as the results of alcoholic and other poisoning, affect the germ-cells, and thus the offspring. A disease may saturate the body with toxins and waste-products, and these may provoke prejudicial germinal variations.

(c) Though modifications due to changed "nurture" do not seem to be transmissible, they may be reimpressed on each generation. Thus " nurture" becomes not less, but more, important in our eyes. "Is my grandfather's environment not my heredity?" asks an American author quaintly and pathetically. Well, if not, let us secure for ourselves and for our children those 
factors in the "grandfather's environment" that made for progressive evolution, and eschew those that tended elsewhere.

Are modifications due to changed nurture not entailed on offspring? Perhaps it is just as well, for we are novices at nurturing even yet. Moreover, the non-transmissibility cuts both ways: if individual modificational gains are not handed on, neither are the losses.

Is the "nature "- the germinal constitution, to wit, all that passes from generation to generationthe capital sum without the results of individual usury? Then we are freed, at least, from undue pessimism, because of the many harmful functions and environments that disfigure our civilisation. Many detrimental acquired characters are to be seen all around us, but if they are not transmissible, they need not last.

(d) The plasticity of the organism admits of definite modifications being reimpressed on successive generations of individuals, and this is the more important when we consider what has been said in the section on "The Indirect Importance of Modifications." They may serve as modificational screens until coincident variations in the same direction can emerge and establish themselves. This also cuts both ways in human societies, where natural selection is interfered with, and where naturally prejudicial deviations from the norm are not necessarily punished by elimination.

(e) Of particular importance is the fact that man, in contrast to other creatures, has developed around him an external heritage, a social framework of customs and traditions, of laws and institutions, of literature and art, by which results almost 
equivalent to the organic transmission of certain kinds of modifications may be brought about.

$(f)$ Is there not some result of the almost tiresome controversy on " the inheritance of acquired characters," if we are thereby freed from indulging in false hopes, but are forced to the conviction that "nurture" is more important than ever? Although what is "acquired" may not be inherited, what is not inherited may be acquired. Thus we are led to direct our energies even more strenuously to the business of reimpressing desirable modifications, and therefore to developing our functions and environments in the direction of progress.

It may be, however, that our methods must change with the change in our expectations. For though we can, by modification, directly influence the individual, and in some measure even control the expression of his inheritance, it is not through modifications that we can hope directly to influence posterity. Man is a slowly reproducing, slowly varying organism. What is above all precious is the conservation of good stock. No number of veneering modifications-superficial screens of organic defects - can atone for allowing a deterioration of the germinal inheritance to diffuse itself or to accumulate. For progress which is really organic-for progress, that is, in our natural inheritance-we must wait, or rather work, patiently.

Even when it is impossible to do much, there is practical importance in accuracy-which is greatly needed in connection with human heredity. How slow of dying is, for instance, the fallacy that ancient and powerful families are necessarily degenerate. 
In spite of what Galton and other careful workers have said, it is persistently asserted that noble and illustrious families usually end in sterilitya mistake largely due to ignoring the female lines of descent.

Inheritance of Moral Character.-In the development of " character" much depends upon early nurture, education, and surrounding influences generally, but how the individual reacts to these must largely depend on his inheritance. Truly the individual himself makes his own character, but what does that mean but the habitual adjustment of an hereditarily determined constitution to surrounding influence? Nurture supplies the stimulus for the expression of the moral inheritance, and how far the inheritance can express itself depends on the nurture-stimuli available just as surely as the result of nurture is conditioned by the hereditarily determined nature on which it operates. It may be urged that character, being a product of habitual modes of feeling, thinking, and acting, cannot be spoken of as inherited, but bodily character is similarly a product dependent upon vital experience. Some children are " born good" or " born bad," just as some children are born strong and others weak, some energetic and others "tired " or "old."

It is entirely useless to boggle over the difficulty that we are unable to conceive how dispositions for good or ill lie implicit within the protoplasmic unit in which the individual life begins. The fact is undoubted that the initiatives of moral character are in some degree transmissible, though, from the nature of the case, the influences of education, example, environment, and the like, are here more 
potent than in regard to structural features. We cannot make a silk purse out of a sow's ear, though the plasticity of character under nurture is a fact which gives us all hope. Explain it we cannot, but the transmission of the raw material of character is a fact, and we must still say, with Sir Thomas Browne: "Bless not thyself that thou wert born in Athens; but, among thy multiplied acknowledgments, lift up one hand to heaven that thou wert born of honest parents, that modesty, humility, and veracity lay in the same egg, and came into the world with thee."

Three General Conclusions.-(1) The study of inheritance is apt to leave a fatalistic impression in the mind, and to some extent this is justified. We cannot get away from our inheritance. As the poet Heine said, half laughingly half bitterly: "A man should be very careful in the selection of his parents." On the other hand, looking forward, we may change the word " parent " into " partner," recognising that a good inheritance is the most precious of all possessions, and that it should be guarded from mixture with bad stock.

(2) But, again, the conclusion is strongly borne in on us that a good nurture is the necessary complement of a good nature and the individual corrective of a poor nature.

(3) If there is little or no scientific warrant for our being other than extremely sceptical at present as to the inheritance of acquired characters-or better, the transmission of modifications-this scepticism lends greater importance than ever, on the one hand, to a good " nature," to secure which is the business of careful mating; and, on the other hand, to a good " nurture," to secure which for our 
children is one of the most obvious and binding duties : the hopefulness of the task resting especially upon the fact that, unlike the beasts that perish, man has a lasting external heritage of ideas and ideals, embodied in prose and verse, in statue and painting, in cathedral and university, in tradition and convention, and above all in society itself. 

CHAPTER VI

SELECTION: ORGANIC AND SOCIAL 



\section{CHAPTER VI}

\section{SELECTION : ORGANIC AND SOCIAL}

Influence of Malthus-Darwin's Position-The Theory stated-The Theory of Natural Selection to be tested as an Interpretative Formula-Illustrations of Natural Selection-Objections and Criticisms - Adaptations-Changes since Darwin's DayEvidences of Natural Selection-Lessening the Burden of the Theory-Sexual Selection-Isolation-Gradual Diminution of Natural Selection in Mankind-Contrast between the Human Race and the Animal World-Some Natural Selection remains-The Dilemma of Civilisation-The extreme laissezfaire Position-Social Surgery-How far is Social Selection compensating for Diminished Natural Selection ?-Reversed Selection in Human Society-Summary of the ArgumentConstructive Suggestions-Selection of Eutopias-Selection of Healthful Occupations-Eugenic Selection.

DARwIN is often called the Newton of biology, though some say he was rather its Copernicus. In any case, he discerned in nature the working of a great process, which has helped us to understand how things have come to be as they are. Among his services there is none greater than this, that he discovered the efficacy of Natural Selection, which means Nature's sifting. The raw materials are inborn variations; the internal condition is the heritability of the favourable variations; the external condition is the struggle for existence; the process of sifting is discriminate elimination; the result is the survival of the fittest to the given conditions.

INFLUENCE OF MALTHUS.-Adumbrations of the 
general idea of selection are to be found in various pre-Darwinian documents, ${ }^{1}$ but it was to Malthus only that Darwin, who was very generous in dealing with anticipations, owned any debt. He speaks of this in a well-known passage in his "Autobiography": "In October, 1838, fifteen months after I had begun my systematic inquiry, I happened to read for amusement 'Malthus on Population,' and, being well prepared to appreciate the struggle for existence which everywhere goes on from long-continued observations of the habits of animals and plants, it at once struck me that, under these circumstances, favourable variations would tend to be preserved and unfavourable ones to be destroyed. The result of this would be the formation of new species. Here, then, I had at last got a theory by which to work."

Twenty years after-Darwin having published no theory meanwhile-history repeated itself. Alfred Russel Wallace was collecting insects at Ternate and suffering badly from fever. As he was resting one day between fits, he happened to recall Malthus' "Principles of Population" which he had read about twelve years before-the first book that he had come across approaching philosophical biology. He thought of what Malthus had said regarding the way disease, famine, and war keep down the population of savage races to a much lower average than that of civilised peoples; he thought of the similar elimination that goes on in the animal world, and it occurred to him to ask the question, "Why do some die and some live?" "And the answer was, clearly, that on the whole the best fitted live. From the effects of disease the most

i E.g. by Charles Wells, Patrick Matthew, James Cowles Prichard. 
healthy escaped; from enemies, the strongest, the swiftest, or the most cunning; from famine, the best hunters or those with the best digestion; and so on. Then it suddenly flashed upon me that this self-acting process would necessarily improve the race, because in every generation the inferior would inevitably be killed off and the superior-that is, the fittest-would survive. Then at once I seemed to see the whole effect of this. ..." His words in the 1858 paper were : "If any species should produce a variety having slightly increased powers of preserving existence, that variety must inevitably in time acquire a superiority in numbers." Thus, for the second time, from the domain of human society the idea of natural selection was suggested.

Perhaps the suggestion was made a third time, for it is an interesting fact that in 1852-six years before the theory of natural selection was launched by Darwin and Wallace, when Herbert Spencer wrote his famous evolutionist article on "The Development Hypothesis," he published another important essay entitled, "A Theory of Population," toward the close of which he came within an ace of recognising that the struggle for existence was a factor in organic evolution. Spencer was not guilty of reading much, but it would be striking if he too had been stimulated by Malthus. In any case we have the fact that, at a time when pressure of population was practically interesting men's minds, Darwin, Wallace, and Spencer were independently led towards a theory of organic evolution. There could be no better illustration of the Comtian thesis that science is a social phenomenon. Prof. Patrick Geddes suggests that 
the severity of industrial competition, which had increased bitterly between Malthus's time and Darwin's, was at least subconsciously in the mind of both Darwin and Wallace, and gave spring to the theory which they projected upon nature. ${ }^{1}$

Darwin's Position.- - Let us try to understand Darwin's problem. His studies as a naturalist had made him acquainted with a large number of animals and plants, and two facts had especially impressed him: first, that the various kinds are suited to the niches which they fill-suited often as hand to glove; and second, that in many cases the various kinds are closely linked together by resemblances which evidently mean blood-relationship. What Darwin wished to get at was a theory of the origin of one species from another, and a theory of the origin of the adaptations with which the world of life is full. He found the answer to both his questions in discovering a process actually at work-Nature's sifting of the changes that crop up. He defined it as "the preservation, during the battle for life, of varieties which possess any advantage in structure, constitution, or instinct."

1 Following Bacon, we may draw a useful distinction between a scientific theory in the stage of suggestion-an anticipation of nature, and a scientific theory in the stage of verification-an interpretation of nature. In the stage of suggestion the theory of natural selection was in greater part sociomorphio; but it passed, by Darwin's careful workmanship, into the stage of verification, and it should be remembered that the validity of a scientific theory is not affected by what suggested it. A theory is to be estimated by its power of formulating a definite order of facts.

At the same time those who insist on using the formula of natural selection in the interpretation of human affairs, and who call it a biological formula, must remember the history-that it was from the human domain that the suggestion of the theory came. Perhaps there is some supplementary suggestion from human s ociety, equally valuable, which no Darwin has yet arisen to appreoiate. 
His general line of thought was something like this. The gardener and the breeder watch for changes or variations; they select for propagation those variants that please them, keeping all others away; gradually they establish new varieties that breed true. So it is in nature, Darwin said, where variations are continually cropping up. But what takes the place of the breeder? Nature's sifting in the struggle for existence. Man has done much in a short time; what may Nature not have done in a long time? As has often been pointed out, there are some differences in detail between artificial and natural selection, but the essential features are the same.

"The theory of natural selection," Mr. Wallace writes, " commonly called Darwinism, is one of the most simple and easy of comprehension in the whole range of science; yet, after fifty years of continuous exposition and study, there is perhaps none that is so widely and persistently misunderstood." Let us therefore linger over it.

When one visits that scientific Aladdin's cave called the British Museum (Natural History), one is impressed, on entering, by the statue of Darwin, and from it the eye falls to a tree full of pigeons with the wild rock-dove (Columba livia) as a centre, and on the branches round about Pouters and Carriers, Tumblers and Trumpeters, Jacobins and Fantails, and other breeds. That case of pigeons is a Darwinian diagram, for Darwin chose these birds for special study-and they led him to a goal as famous as Ararat. There are over two hundred very well-marked breeds of domestic pigeons, and there are at least ten that would be 1 Fortnightly Review (March 1909), p. 411. 
ranked as distinct genera if they occurred wild. Yet there is strong evidence that all are scions of the blue rock-pigeon (Columba livia). Darwin pointed out that the social, non-arboreal habits, the mode of cooing, and other characters of domestic pigeons, point to Columba livia; that this bird has a wide range of distribution; that it is very variable in plumage, easily tamed, and actually domesticated; that all races of domestic pigeons are fertile when crossed, and their offspring are usually fertile-two facts which point to one origin for all; that all domestic pigeons tend to revert to the blue rock-pigeon; and so on.

In the same way, as is well known, Darwin brought forward evidence that all the breeds of poultry-Hamburghs and Dorkings, Bantams and Silk-fowl, and all the rest of them-are descended from the jungle-fowl, Gallus bankiva, which is still found wild in some parts of India and the Malay Islands. There seems to be evidence that the jungle-fowl-which our gamecock most nearly resembles-was domesticated in the East before 1400 B.c., and was introduced into Europe about 600 B.c. The clear cases of pigeon and fowl were backed up by more difficult cases, such as those of horse and dog, where it seems almost certain that the domesticated breeds have arisen from several distinct wild species.

At all events, Darwin proved, up to the hilt, that the breeder is a transformist. Circe changed men into pigs; the prehistoric breeders made a wolfish creature into a trustworthy guardian of their flocks. What is the method? The breeder cannot create; he waits for what turns up, and then he 
directs. He directs by bringing similars together and by eliminating undesirables from the flock or herd. So Nature directs-but automatically -by singling and sifting in the struggle for existence.

The Theory Stated.-(1) Darwin started with the fountain of change within the living creature, whence variations are always welling forth. Offspring are not quite like their parents, or like one another. It is a fact that there are individual variations, for better and for worse, between living creatures of the same kind. In some cases it is definitely known that these variations may be transmitted.

(2) Life is very prolific, and in every kind of living creature-except man-the majority die young. There is not usually any increase in numbers from generation to generation. There is a ceaseless struggle for existence-a phrase to be taken in a wide and metaphorical sense as a description of what goes on in nature because of the limits of space and the self-assertiveness of the individual, because of the prolific multiplication of the eaters and the insufficiently rapid supply of the eatable, because of the changeful and merciless physical environment, and all the subtle interrelations of things in the web of life, whose warp and woof are love and hunger.

It is very important to realise the web of life in this connection, for, as an acute critic points out, it alone warrants us in believing that "slight differences may give one creature an advantage over its neighbour in a nicely balanced struggle for life. In other words, it introduces the conception of a correlation between even minute variations and 
the survival or non-survival of their possessors." 1 As Darwin says, in a notable passage: "Battle within battle must be continually recurring, with varying success; and yet, in the long run, the forces are so nicely balanced that the merest trifle would give the victory to one organic being over another."

(3) The theory continues, that, if variations occur in the direction of increased fitness, and if the variations are heritable, and if there is discriminate elimination with reference to these variations, then the possessors of the fitter variations must be favoured with longer life and larger families-with survival, in short. And if this is kept up consistently, then new adaptations, and, with the help of isolation, new species, will arise. Those members of a species that are handicapped will become a minority and eventually their type will be eliminated. Those that have varied so as to be in any appreciable way favoured will become the majority, and eventually the type, of the species.

A little refection will show that there are two main modes of natural selection. It may produce its effects by the discriminate elimination of the less fit, or by the increased and more effective reproductivity incident on the success of the more fit. These two modes are sometimes distinguished as Lethal and Reproductive Selection respectively. In both cases the fitter members of a generation contribute more than the less fit to the next generation. If we regard sexual selection as a special case of natural selection, which seems the clearest view, we have to include extreme cases like that

1 "Evidence of Natural Selection," by E. S. Russell, in Rivista di Scienza (1908), vol. iii. 
of the single drone that overtakes the queen-bee in her nuptial flight-all the others being left to die non-reproductive.

Darwin summed up the theory in a couple of sentences: "As many more individuals of each species are born than can possibly survive, and as, consequently, there is frequently recurring struggle for existence, it follows that any being, if it vary however slightly in any manner profitable to itself, under the complex and sometimes varying conditions of life, will have a better chance of surviving, and thus be naturally selected. From the strong principle of inheritance any selected variety will tend to propagate its new and modified form."

The Theory of Natural Selection to be TESTED as aN INTERPRetative Formula.-For what has occurred in the past the theory of natural selection can never be proved; we can only show that it offers a reasonable interpretation, that it is a formula that fits. In the case of many of the most remarkable adaptations, such as those of mimicry and protective resemblance, it is the only interpretation in the field that has any approach to feasibility.

In regard to what is going on at present, several attempts have been made (as we shall see later) to catch natural selection at work, to prove the occurrence of discriminate elimination with reference to a particular character, to show that what determines that one organism should be taken and another left is that the first lacked something which the survivor has. This is extremely important, for it is " as easy as winking" to imagine possible utilities for a particular character, whereas 
it is our business to prove that the survivors survive because they have the character in question.

Illustrations of Natural Selection.-In the 1858 essay Darwin gave the following imaginary illustration. Some dog-like animal lives on rabbits, and on hares, when it can get them; the rabbits become scarcer, and the hares more plentiful, so the carnivore turns its attention to hares; those carnivores that varied in the direction of swiftness and sharp-sightedness would get on best, would be more successful as regards numbers and vigour of offspring; in a thousand generations there would be a marked effect-as surely, he said, as greyhounds can be improved by selection and careful breeding.

Many insects in Madeira have reduced and useless wings, or none, while their allies in Europe have them well developed. The Darwinian interpretation is, that as Madeira, like similar islands, is exposed to sudden gales, the flying insects have been blown out to sea, while those that varied in the direction of flightlessness have survived. It is easy to make fun of this, as Samuel Butler did when he said it was like explaining our own presence by the fact that our cousins, uncles, and aunts had gone away. A little reflection, however, will show that the theory fits the facts, and our confidence in the interpretation grows when we find that other exposed and wind-swept islands agree with Madeira in having flightless insects. Thus, in the stormy and shelterless Kerguelen all the insects (including a moth, several flies, and many beetles) are flightless and most are wingless. Many Arctic mammals and birds-such as fox and falcon-have a beautiful white colour: what 
is the selectionist interpretation of this characteristic? The first step is to recognise that animals are very variable as regards colouring, and thus there is raw material to work on. Furthermore, a variation in the direction of whiteness is commonwhite blackbirds and swallows, white rats and moles, being well known. It seems likely that a ferment essential to the manufacture of the pigment drops out of the inheritance of these albinos. The change is of germinal origin, and it is hereditary. Now there is a keen struggle for existence in Arctic regions, and any character that gives its possessor a pull is likely to have selective value. But there are various advantages in a white dress in snowy regions-it is the least conspicuous and the most comfortable. Those who turn white will get on best, other things being equal. Therefore we have white races in Arctic regions, and we may corroborate the argument by referring to a simple experiment. Prof. Davenport had 300 chickens in a field, 80 per cent. white or black and conspicuous, 20 per cent. spotted and inconspicuous. In a short time twenty-four were killed by crows, but only one of the killed was spotted.

In a heavy snowstorm at Johannesburg in August 1909, many hundreds of trees were destroyed by the weight of snow on the branches. It was interesting, after the storm, to notice that the elimination was in a marked degree discriminate. The trees that suffered most were the imported Australian trees, such as Blue Gums and Black Wattles, quickly growing, with soft wood, and with abundant foliage that caught the snow. On the other hand, the deodars from the Himalaya 
Mountains, constitutionally adapted to let the snow slide from their pendulous branches and acicular leaves, had hardly a twig broken. If similar storms occurred several times a year, instead of once in twenty years, there would soon be no Blue Gums or Wattles.

Objections ANd CRITicisms.-Darwin's suggestion was that new adaptations, new varieties, new species have arisen by the elimination of the relatively unfit variants and by the selection of the relatively fit. In other words, natural selection is the main directive factor in evolution. That is to say, given variations, the secret of success is sifting. Against this theory all manner of objections have been urged-fair and unfair, competent and incompetent, wise and foolish. The army of objections is so huge that one feels there must be strong virtue in a theory that is so vigorous after fifty years. It should always be remembered that the best and the severest critic of the theory of natural selection was Charles Darwin himself. ${ }^{1}$ We do not propose to defend the theory or to slay the thrice slain, but the following statements may serve to remove some common misunderstandings.

(1) It must be clearly understood that the "fittest" which survive are not necessarily best or highest on any absolute standard, but simply fittest for the given conditions. The liver-fluke is "fit," as well as the sheep.

(2) Until we know more about the origin of the variations which form the raw material of

1 An admirable statement of the objections to the theory of natural selection, and an answer to them, will be found in Prof. Plate's "Handbook to Darwinism." (Leipsig, 1908.) 
progress we are open to the reproach of giving a theory of the survival, but not of the arrival of the fittest. Yet there are often two misunderstandings in the minds of those who play with this reproach, which Darwin met long ago. (a) It is, of course, clear that natural selection is Siva, the Destroyer, ${ }^{1}$ and that L'Evolution créatrice is the secret of the organism. Natural selection prunes a growing and changeful tree. Natural selection is a directive, not an originative, factor. The problem of origins is the problem of variation. (b) It must also be noted that, if the fittest have arisen by very gradual steps, by the accumulation of variations small in amount, then the reproach of explaining, not the arrival, but only the survival, loses much of its force.

(3) With unwearying reiteration the objection is raised that the initial stages of new adaptations will be too minute to have survival value. This difficulty has been often dealt with, and it may suffice here to point out $(a)$ that no one can decide, in an a priori way, how small a change may be of critical moment; $(b)$ that in the fine texture of the web of life a trivial difference, as Darwin said, may determine survival; (c) that elimination may be effective though it is not accomplished in a generation; and $(d)$ that an incipient change

1 Most biologists admit, what Darwin himself clearly recognised, that in strictness the real process is natural elimination. As an American biologist says: "The fit are not selected-it is the unfit who fail to survive, and the fit are merely the survivors. The process is negative throughout. A railway train selects its passengers in the same sense-those who come in time get aboard, those who do not, get left." At the same time it must be understood that, although the process is negative, the results are in part positive. 
may be carried through its initial stages by being correlated with another more important change.

(4) The eliminative processes that most Darwinians believe in, because they see them going on, may be slow as well as quick, gentle as well as severe, environmental as well as competitive. The selected are not necessarily those saved from the jaws of violent death; they may be simply those who, in virtue of a heritable peculiarity, have a rather longer and more successful life and a rather larger and more successful family. The only eliminative processes that can be believed in as counting for much in evolution are those which are discriminate and consistent. Thinning turnips may serve as our diagram of indiscriminate elimination (only very indirectly does it improve the turnip race); Luther Burbank carefully burning some of his most interesting creations because they are not quite right for his purpose may serve as our diagram of discriminate elimination. But while the modes of natural selection are many and various, the logic of the process is always the same-when a heritable peculiarity is of critical moment in favouring survival it will tend to persist, provided $(a)$ that its occurrence is sufficiently frequent, and (b) that the discriminate selection fostering it is kept up consistently for a long enough period.

AdaPtations. - No one can rightly appreciate the theory of natural selection who does not realise in some measure the universal occurrence of those detailed fitnesses of structure and function which are called adaptations. ${ }^{1}$ The general idea

1 We use the word adaptation to express a result achieved; it is aometimes used to express the process of reaching that result. 
of fitness is familiar; we are irresistibly pleased in our own affairs with arrangements like safetyvalves and regulators which bring about important results in an effective way; we pour contempt on tools that will not work, on machines that will not go. But we have not to travel beyond our own bodies to find illustrations of safety-valves and regulators that put to scorn all machinery, and one of the perennial delights of natural history, in the wide sense, is its continual discovery of fresh instances of hand-and-glove adaptations.

There is wonderful fitness even in one of the lowest forms of life-it is always changing and yet it remains the same, it answers back effectively to external stimuli, it grows and passes from one phase to another, it reproduces itself, and it is said that some of the simplest never die. We cannot, at present, get behind this primary adaptiveness of living creatures-it is implied in what we mean by living. It is convenient, however, to keep the word "adaptation" for something super-added to what we must take for granted, and yet it is difficult to draw the line. The power of growth is a primary attribute; the capacity of regrowing a readily broken limb depends on this; and yet it is difficult to understand why, for instance, a chameleon should not be able to regrow its tail, as almost all other lizards can do, unless we regard the distribution of the regenerative capacity as adaptive, adjusted in the course of ages to frequently recurrent needs. We say that the immunity which certain organisms have to certain poisons is an adaptation, it has been wrought out and added on; but is it not, perhaps, a special case of the immunity which even simple 
organisms have to considerable accumulations of their own self-made poisons or waste-products?

To illustrate adaptations Weismann takes, for instance, the whale-type among mammals, and refers to " the fish-like form of the body, the hairlessness of the skin, the transformation of the fore-limbs to flippers, the disappearance of the hind-limbs and the development of tail-flukes, the layer of blubber under the skin, which affords the protection from cold necessary to a warmblooded animal," and so on through a long list. The whale is a great bundle of adaptations to a mode of life which is peculiar for a mammal.

Whether we take actively functional parts, such as our own hand, or passively functional structures, such as a feather; whether we take obvious features, such as the typical spindle-like shape of fishes, or more recondite features, such as the structure of a bone; whether we take mimicry or migration, "wherever we tap organic nature," as Romanes said, "it seems to flow with purpose."

Natural selection is the theory of the indirect coming about of this wide-spread purposefulnessthe possibility of variations in the direction of fitness being granted. Lamarckism, which assumes the hereditary accumulation of functional and environmental modifications, is a theory of direct adaptation-on the whole simpler than the selection theory, but suffering from the serious disadvantage that its fundamental assumption is still without cogent evidence in its favour.

Birds' eggs are of diverse shapes, and we know in some detail the actual factors which determine these. We also know that individual variations in the shape are not uncommon. We can under- 
stand, then, that if a certain shape were particularly well suited for special conditions, that shape would be selected, i.e. the birds that were constitutionally unable to lay eggs of the fit shape would be eliminated. Now Darwin points out that, in sea-birds like guillemots and razor-bills, which lay their eggs on the narrow ledges of precipitous cliffs, the shape of egg is very markedly top-like. The adaptiveness of the shape is that, if the egg be jostled by the parent or some other bird, or be caught in a swirl of wind, it rotates on its short axis without rolling from its original position.

Let us take another instance. The Essop prawn (Hippolyte varians) may be red, yellow, blue, orange, olive, violet, brown, green, and other colours. It is born without a bias and it takes on the colour of its surroundings, both when young and when adult. Put some in a glass aquarium, and line the sides and floor with paper of almost any colour; the prawn follows, and from one colour it may be changed to any other.

As bright yellow, blue, and violet are not common colours among the seaweed, it has been argued that the power of colour-change cannot be the outcome of selection. But that is an absurd conclusion; it is by no means certain that the bright colours are absent among seaweed, and, besides, adaptiveness is rarely perfect.

Many colour-adaptations are very striking. Thus Prof. Poulton has shown that certain caterpillars will, within certain limits, take on the colour of their surroundings, and Engelmann has shown that the peculiar algæ known as Oscillatoria become green in red light, red in green lightphysiologically the best possible colours. 
We may speak of an organism as a bundle of adaptations, but we are not justified in saying that every structure is an adaptation. There are some structures whose use is unknown, and there are others which seem to be of no value, such as wellconcealed decorativeness. It may be, however, that some of the details whose significance is unknown are the architectural correlates of important characters.

Changes since Darwin's Day.-Darwin did not doubt the legitimacy of supposing that some of the direct effects of use and disuse and of the influence of surroundings may be transmitted as such or in a representative degree. He was, therefore, to a limited extent a Lamarckian, and there are some competent authorities who occupy a similar position. We are far from dogmatically declaring that the Lamarckian position is quite untenable, but we have hinted at some of the difficulties which have led us to abandon it until further evidence is forthcoming.

Leaving this as a drawn battle, we wish to refer briefly to two marked changes since Darwin's day. In the first place, there has been a useful attempt to give some experimental demonstration of the working of natural selection. In the second place, there is a growing feeling among different bodies of workers that it is not necessary to burden the shoulders of the natural selection theory so heavily as heretofore.

Evidences of Natural Selection.-One of the most interesting - though, from the nature of the case, least impressive-steps of progress since Darwin's day is the attempt to secure definite evidence of the operation of natural selection. 
It must be admitted that Darwin left the theory in this form: Variations occur abundantly; there is a complex, subtle struggle for existence; there is a constant process of sifting and winnowing; if fit variations occur among the rest, and if there is discriminate elimination so intense that survival depends on the presence or absence of the variation in question, then new adaptations must result. Those who have something of a naturalist's experience and have some appreciation of the enormous scale upon which Nature works-as to time, as to numbers, as to chances-have usually been content to accept this theory of natural selection as a good working hypothesis.

But what we wish is actual proof of discriminate elimination, that survivors do survive in virtue of particular qualities. A few illustrations in the present may legitimise our belief that similar processes occurred in the past. Let us summarise the best of these illustrations.

With silk threads Cesnola ${ }^{1}$ tethered forty-five green praying mantises to green herbage, and sixtyfive of the brown variety to withered plants. He watched them for seventeen days, and all survived unnoticed by birds. But when he put twenty-five green ones among brown herbage all were killed by birds in eleven days, while of forty-five brown ones on green grass, only ten survived at the end of seventeen days. Here we have definite proof of a selective death-rate, definite proof of the selective value of the protective coloration.

Poulton and Saunders ${ }^{2}$ fastened 600 pupæ of the

1 See " Biometrika," vol. iii. p. 58.

2 "Report of the British Association, Bristol Meeting" (1899), pp. 906-909. 
tortoise-shell butterfly (Vanessa urtica) to nettles, tree-trunks, fences, walls, and so on. At Oxford there was a mortality of 93 per cent., pointing to an extremely high elimination-rate, and the only pupæ that survived were on nettles, where they were least conspicuous. At St. Helens, in the Isle of Wight, the elimination was 92 per cent. on fences where the pupæ were conspicuous, as against 57 per cent. among nettles where they were inconspicuous. Here, again, there is definite evidence of discriminate elimination.

Another illustration is to be found in the late Prof. Weldon's ${ }^{1}$ well-known experiments on crabs. He placed 248 male shore-crabs (Carcinus monas) in a vessel of sea-water containing in suspension a quantity of china-clay; and 94 survived. It was found that the mean of the frontal breadths of the survivors was distinctly smaller than that of the eliminated. "A difference in the mean value of a character between survivors and eliminated, when both have been exposed to identical environmental conditions, is proof that the character is being acted upon by natural selection. . . ."2 That is, by the ordinary " secular selection," for there is another mode-“" periodic selection," in which the mean value of the character is not changed, but extreme deviations from the mean are lopped off. "Periodic selection" can be detected by the decrease in the range of variability.

Measuring small specimens (10-15 mm.) of shore-crab taken from Plymouth Sound, in the

1 "Proc. Royal Soc." (1895), vol. lvii. pp. 360-79. Also Nature (1898), vol. lviii. pp. 499-506 and 595-6.

2 See "The Evidence of Natural Selection," by E. S. Russell, in Ririsia di Scienza (1908), vol. iii. 
years 1893, 1895, and 1898, Prof. Weldon found that, during the time between the first measurement and the last, the frontal breadth of the crabs, taken relatively to their length, had distinctly decreased. As the amount of suspended clay and sewage in Plymouth Sound had increased during the same period, Prof. Weldon concluded that those with broad fronts were being persistently eliminated. As the experiment referred to above shows, those with narrow fronts withstand the muddy water better. ${ }^{1}$ The inference was that the elimination was definitely discriminate.

Prof. Bumpus ${ }^{2}$ relates an interesting observation on the house-sparrow in North America. After a storm 136 were picked up and brought into the laboratory, where 72 revived and 64 succumbed. Survivors and eliminated were measured as to length, size of wing, weight, length of head, length of humerus, of femur, of tibio-tarsus, width of head, and length of sternum. For all but the last of these characters the range of variation was considerably greater in those that succumbed, the extreme variants (e.g. those with longest as well as shortest wing-span) were eliminated (periodic selection). Moreover, the survivors were a little shorter, lighter, longer in the leg, the humerus, and the breast-bone. General stability of structure, Prof. Bumpus says, was the essential characteristic of the survivors.

A fine proof of the efficacy of natural selection

1 For criticism see J. T. Cunningham, in Nature (1898), vol. lviii. pp. 593-4.

2 "The Elimination of the Unfit as Illustrated by the Introduced Sparrow," by Hermon C. Bumpus, Biol. Lect. Woods Holl, Boston (1898), pp. 209-26. 
is given by Prof. H. E. Crampton ${ }^{1}$ for the Saturnid moth, Philosamia cynthia. A large number of pupæ were collected from a small areas and kept till they hatched. But only 16.6 per cent. of the total number collected gave perfect moths. Many of the pupæ were dead within the cocoon (" pupal elimination "), 129 out of 310 died in the period between the formation of the imago and its emergence (" pupal imaginal elimination"). Mr. Crampton compared 134 male pupæ that survived pupation with 130 that died immediately after pupation, as regards length, width, and depth of the bust of each, and as regards length and breadth of antennæ. Those that survived were longer, narrower in the bust, and had longer, stouter antennæ. Similarly, he compared 176 surviving female pupæ with 180 that died, and selection in type was found to be certain for all dimensions and to be in the same direction as in the male pupæ. The survivors were also less variable. We need not discuss the pupal-imaginal elimination, where the results were somewhat different. It is interesting to notice, as Mr. Crampton points out, that the selected characters are not such as seem to be directly or indirectly " useful" to their possessors, yet they are demonstrated to have the high utility of determining survival-which is indeed, for the evolutionist, the final criterion of utility. ${ }^{2}$

We cannot do more than allude to the careful statistical methods by which Prof. Karl Pearson and others have proved that there is selective

1 "Biometrika" (1904), vol. iii. pp. 113-30.

2 See "The Evidence of Natural Selection," by E. S. Russell, in Rivista di Scienza (1909), vol. iii. 
death-rate in man. A certain number of people are killed every year in Britain by lightning; their death is purely fortuitous. But this cannot be said of phthisis, where the elimination is in part quite definitely discriminate. Even from the fact that longevity is truly heritable it is evident that there must be a selective death-rate in mankind.

Lessening the Burden of the Theory.another change which seems now coming about as the result of discussion and investigation is expressed in a growing tendency to lessen the burden that has been hitherto laid-faute de mieux-on the shoulders of Natural Selection. We cannot do more than illustrate how different bodies of workers are arriving at the same general conclusion.

(a) If we find increasing warrant for postulating the occurrence of mutations of considerable magnitude and for believing that they are not readily lost when they once emerge, then it is not necessary to suppose that every character has arisen by the accumulation of minute steps. It goes without saying that mutations must pass through the selection sieve.

(b) Whether we postulate mutations or fluctuations, we cannot but sympathise with the heresy which is often whispered, that it is very difficult to give a concrete selectionist interpretation of what may be called the "big lifts" ${ }^{1}$ in evolution.

1 The difficulty in regard to "big lifts" is bound up with the question whether there are any qualitative steps in evolution, or whether change apparently qualitative may not be due to the accumulation of minute quantitative changes. It is said that there are no transitions between a sledge and a wheeled cart, and that a new unity cannot arise piecemeal. It is difficult, however, to feel confidence in these arguments from analogy. Conscience, or the habit of judging our actions by a standard, is a very distinctive 
Given heritable fluctuations and selection, we can perhaps interpret the perfecting of an adaptive structure, such as an elephant's trunk. Given mutations and selection and isolation, we can perhaps interpret the origin of a new species. But when we face the "big lifts" the difficulty is very great. Gymnosperms have probabiy evolved from fern-like plants. But " the seed and all that goes with it is a new character, and how selection could have originated it is a question at whose answer even scientific imagination balks. It is evident that the ovules of Gymnosperms are related by descent to the sporangia of ferns in some way, but so extensive a change does not seem to come within the possibilities of natural selection." 1

It may be noted that some palæobotanists, notably Grand'Eury and Zeiller, maintain that the rock-record is distinctly suggestive of the sudden appearance of new forms differing by marked characters from those that gave them birth.

(c) Another view which finds adherents is that many minor characters are the physiological or developmental concomitants of major characters which have undeniable selection-value. They follow in the wake of the more primary qualities. Thorns used to be interpreted by the eager Darwinians as a protection against grazing animals, and human character, and yet it is conceivable that it has evolved from pre-human habits by a series of very slight changes, some of the links being found in self-subordinating behaviour among animals, in parental care, in the law of the pack. As Norman Wilde puts it, "Because darkness passes through twilight into day by imperceptible degrees, we do not deny the difference in quality between darkness and light."

1 "The Theory of Natural Selection from the Standpoint of Botany," by Prof. John M. Coulter, in "Fifty Years of Darwinism" (1909), p. 60. 
they seem sometimes to have this value. But this cannot be the whole truth. Apart from the just objections that thorns are often prevalent in countries where there are few grazing animals and that they do not appear in the early stages when they are most needed, experiment has shown that many thorns arise in response to poor nutrition. ${ }^{1}$ Thorns are the natural outcrops of a kind of constitution suited to dry countries.

This idea was familiar enough to Darwin, as we see from the emphasis which he laid on instances of " correlated variability." In this connection, Sir Ray Lankester observed, at the Cambridge Centenary Celebrations: "In my opinion he has thus furnished the key to the explanation of what are called useless specific characters and of incipient organs. That key consists in the fact that a general physiological property, or character of utility, is often selected and perpetuated which carries with it distinct, even remote, correlated growths and peculiarities obvious to our eyes, yet

1 See Coulter, op. cit. (1909), and Geddes, "Proc. Brit. Assoc." (1889.) Prof. Coulter points to significant facts like the following: the nettle can get on quite well without its stinging hairs; many seeds, especially in arid regions, develop a testa so hard that it inter. feres with the breaking through of the embryo-which looks like "over-adaptation"; further investigation has played havoc with the pretty story of the extra-floral nectaries attracting a body-guard of harmless ants. It is probable that in these and a hundred other cases our task is rather that of discovering the physiological and embryological significance of the structures in question, than that of searching diligently for a utilitarian justification which does not exist. A familiar example may be found in our finger-prints, which illustrate discontinuity in evolution-the apparently abrupt origin of new patterns; but, as we have no warrant for supposing that natural selection operates in any way in this case, we must suppose that these patterns are the expressions of internal growthconditions. 
having no functional value. At a later stage in the history of such a form these correlated growths may acquire value and become the subject of selection." 1

(d) Among palæontologists, too, there are some, like Prof. H. F. Osborn, who make out a strong case for the origin of new characters by definite progressive variation, and "not by the selection of the fit from the fortuitous." In other words, many palæontologists claim that indefinite variations off the main line are absent, so far as the rock-record tells.

"The law of gradual appearance or origin of many new characters in definite or determinate directions from the very beginning I regard as the grandest contribution which palæontology has made to evolution." 2 We must attach great importance to this expression of opinion, for it is shared by many who, like Prof. Osborn, have given their life to studying the actual history; but it must be borne in mind that highly specialised types, like Ammonites and mammals, may be like well-pruned trees-they may have been selected through long periods into lines of determinate variation. The power of divergent idiosyncrasy may have been pruned out of them.

After referring to the work of Waagen on Ammonites and his own work on mammals (e.g. their teeth), Prof. H. F. Osborn says : "The law of gradual change in certain determinate, definite, and, at least in some cases, adaptive directions, through very long periods of time, and the absence

1 Nature (July 1, 1909), p. 10.

2 "Darwin and Palæontology," by H. F. Osborn, in "Fifty Years of Darwinism" (1909). 
of chance and non-direction in the origin of a large number of adaptive and other new characters, is the common working principle both in Vertebrate and Invertebrate palæontology." 1

(e) Another change of view-rank heresy to those of the straiter sect of Darwinians-is seen in the writings of not a few naturalists who do not feel themselves bound to find a use for everything. There are many apparently trivial characters for which careful investigation has discovered very definite and unexpected utility-Weismann gives, as an example, the beautiful microscopic anchors and dises of lime found in the skin of the burrowing, worm-like Holothurians known as Synaptids; but, on the other hand, the tyranny of an extreme zoological utilitarianism may become absurd. When the wind blows the long, sharp-pointed leaf of the sand-binding bent-grass it often makes a perfect circle on the sand, but there is no significance in this. Nor is there in the beautiful ripplemarks on the sand or in the frost-flowers in the window. It seems likely that there are many such things in living creatures-registrations of orderly rhythms of the body, but not useful. The barring on a feather may be of life-saving value, it may also mean nothing more than diurnal variations in blood-pressure when the feather was a-making.

Sexual Selection.-As a corollary to his theory of natural selection, Darwin expounded a theory of sexual selection, in which he interpreted some of the secondary peculiarities of the sexes as the outcome of selective processes involved in the combats of rival suitors and in the choice 1 op. cit. (1909). 
exercised by the coy females. All sorts of masculine weapons, such as antlers; all sort of decorations, such as brilliant plumage; all sorts of excitants, such as love-calls and fragrance, may be interpreted in terms of the sexual selection which seems to occur in many cases, especially where there are more males than females, or where polygamy occurs. The whole matter is difficult, perhaps more difficult than Darwin thought, and there is great difference of opinion in regard to it. Wallace does not see his way to believing at all in the action of female choice; Weismann is wholeheartedly with Darwin. It must suffice to state a few conclusions based on some of the postDarwinian contributions to this fascinating subject.

(a) The combats of rival males are often very fierce. The younger or weaker candidates may be killed, or expelled, or left unmated. In such cases there seems little reason to doubt the discriminateness of the elimination. In some curious cases, as in spiders, the tournaments are prolonged, but the combatants do not seem to hurt one another; and it is possible that the significance of the jousting is to excite the females, who sometimes stand by, as it were interested spectators. In some other cases, e.g. among Lamellicorn beetles and Bearded Monkeys, there seems to be more bluffing than fighting, for precedence is given to the candidate of most imposing appearance.

(b) In regard to those masculine characters which indubitably attract the female and probably serve to excite her and to overcome her coyness, there seems, as Wallace has consistently maintained, very little evidence that the female chooses a partner out of a number of suitors. At the same 
time, there is evidence, in some cases, that certain males are left out in the cold unmated, and that these are inferior in attractiveness or in stimulating power.

(c) While the cases of preferential mating which Darwin relied on, for instance among birds and butterflies, require further study in the light of criticism, there is no doubt that in many cases the males exert themselves to display their special qualities. Thus Prof. and Mrs. Peckham have described, in spiders of the family Attidæ, the extraordinary dances of the males before the females. That the female literally chooses the handsomest dancer remains unproved, yet it is well known that she often punishes a suitor who does not adequately please her by killing him there and then.

(d) In many cases, e.g. the antlers of stags, there is a very intimate correlation between the reproductive organs and the development of the secondary sex characters. It seems that an internal secretion from the reproductive organs is necessary to start the development of certain secondary sex characters. There is also evidence that the secondary differences between males and females hang together physiologically, being manifold outcrops of the deep constitutional difference which makes of one animal an egg-producer and of another a sperm-producer. But this kind of inquiry, still very incipient, is at a level deeper than that of sexual selection, which does not touch the question of origins.

(e) It is now generally believed that what the female chooses is not so much slight improvements in chirping or song, slight excellences in colour 
or scent, but rather the tout-ensemble of that male who most excites her sexual interest. As Weismann says: "Even though we certainly cannot assume that the females exercise a conscious choice of the 'handsomest' male, and deliberate, like judges in a court of justice, over the perfections of their wooers, we have no reason to doubt that distinctive forms (decorative feathers and colours) have a particularly exciting effect upon the female, just as certain odours have among animals of so many different groups, including the butterflies." 1

Though Darwin sometimes seems to credit the female with no small degree of æsthetic fastidiousness, he also states that " it is not probable that she consciously deliberates; but she is most excited or attracted by the most beautiful, or melodious, or gallant males." As Lloyd Morgan says: "The most vigorous, defiant, and mettlesome male is preferred, just because he alone affords a contributory stimulation adequate to evoke the pairing impulse, with its attendant emotional tone." From the human point of view, perhaps the most important point is that, in the course of evolution, sexual behaviour has come to be associated with psychological values which hitch it to the skies.

Isolation.-Besides selection in its varied forms there is another directive factor in evolutionwhich Darwin to some extent recognised-and that is Isolation. This term is used to include all the means which restrict the range of intercrossing within a species: geographical barriers, such as arise when a peninsula becomes an island; temporal barriers, such as arise when the members

1 "Darwin and Modern Science" (1909), p. 47. 
of a species reach sexual maturity at different times of year; habitudinal barriers, when a species splits into two or more castes with different habits of life; physiological barriers, such as arise by some variation in the reproductive organs; and psychological barriers, which rest on profound antipathies. The subject has been worked at a good deal since Darwin's day, by Wagner, Gulick, Romanes, Jordan, and others - and Romanes went the length of saying that Isolation was a sine qua non in the origin of new species. The great difficulty is to get a sufficient body of reliable facts.

From many passages in Darwin's works it is evident that he recognised that isolation, or segregation, is important in natural selection, just as it is in artificial selection. "I do not doubt," he says, "that isolation is of considerable importance in the formation of new species." But he did not analyse the idea as some post-Darwinian workers have done.

When a species spreads, several contingents may become isolated from one another, and, if different variations spring up in the several contingents, then the isolation will favour the origin of distinct species. It works in two ways: (1) by preventing intercrossing and its possibly levelling effects, and (2) by involving close inbreeding, which develops prepotency or stability of type. There is one bird peculiar to Britain, namely, the red grouse, but it is closely allied to the Scandinavian willow grouse, and it seems impossible to doubt that the literal isolation of Britain has allowed the red grouse to diverge as a new species from the willow grouse stock.

There are said to be eighty species of the land- 
snail Cerion on the Bahama Islands, and Gulick reports 200-300 species of the land-snail Achatinella in the various valleys of the Sandwich Island Oahu.

President Jordan has devoted some attention to the occurrence of cognate or "geminate" species on opposite sides of some barrier. "In a general way, such species agree with each other in all the respects which usually distinguish species within the genus. Their differences appear in minor regards, characters of degree, or proportiontraits which we may safely suppose to be of more recent origin than the ordinary characters marking off species within the group." As examples of what are probably in some measure the results of isolation, he takes the following: "Each well-separated island in the West Indies has its own form of golden warbler. Each island in the East Indies has its own forms of reptiles, monkeys, snails, and fresh-water fishes. Each island in Hawaii has its own species of each genus of Drepanine birds; each forest its own type of land-snails. Each of the three groups of rookeries in Bering Sea has its own species of fur-seal. Each section of the Isthmus of Panama has its geminate species of fishes, representing nearly every genus or sub-genus of the shore-water off Mexico." 1

There is considerable evidence to show that isolation, with its attendant inbreeding, has played an important rôle in human evolution, fixing and intensifying and giving hereditary grip to types which began their career in small communities.

1 "Isolation as a Factor in Organic Evolution," in "Fifty Years of Darwinism" (1909), p. 81. 
SEIECTION : ORGANIC AND SOCIAL 213

\section{SELECTION IN HUMAN SOCIETY}

Gradual Diminution of Natural Selection IN Mankind.-In early days man had probably a precarious foothold on the earth, contending with wild beasts and with physical conditions of which he had little mastery. The serpent bit his heel, the thorns cut his naked skin, the floods rose and drowned him in his cave. There was probably much squabbling around the platter of subsistence, a keen and literal struggle, and it may be that we owe much to the natural selection of those ancient days. But as age succeeded age, and man's brain developed, he cared less and less for what serpent or thorn or flood could do; his struggle for existence changed in tone and colour. And nowadays, except in the outskirts of civilisation, there are few wild beasts that worry man much, the serpent that bites his heel is usually more or less microscopic, every year increases his mastery over physical forces, and he is extending his kingdom to the heavens.

All through the ages there has been a winnowing by disease and famine, still very marked in certain peoples, and to this also, as regards some of our qualities, we have probably owed much. Of the primæval crudity of the struggle for existence, to which sections of mankind are sometimes forced back, we get occasional appalling glimpses; for instance, when a panic unmans men altogether. But every one knows that we do all that in us lies to put a stop to elimination by disease and famine. Partly through genuine sympathy, partly 
from a desire to avoid unpleasantness, we insist on keeping the unfit alive.

As the struggle with physical forces and with wild beasts became easier, with more frequent breathing-times and with more encouragement to self-assertiveness, there came to be more competition between fellows, and it may be that we owe much to the deadly inter-tribal wars of ancient times, which would tend to favour not only strength but solidarity. The conflict of races still continues among civilised peoples, in trade as much as in war; and, if there must be this conflict, it is to be desired that, as the result of it, there may be " mastery for the foreseeing nation, for the nation with the cleaner bill of health, the more united purpose of all classes, and the sounder intellectual equipment of its units." 1 It is impossible to ignore, however, that the whole aspect has changed in modern times, and that the issues are less clear. We cannot trust to the selective process with equanimity. It is obvious, for instance, that the issue of the conflict often depends very largely on length of purse and up-to-date-ness of equipment, and only to a slight extent on the organic qualities of the race or people.

Contrast between the Human Race and the Animal World.-It is not necessary to spend time in showing at length that the venue changes greatly when we pass from the animal world to the human race. Apart from the social feelings which make the cruder forms of natural selection intolerable, there are many complicating factors.

(1) Animals have very little power outside their

1 "The Scope and Importance to the State of the Science of National Eugenics," by Karl Pearson. London, 1909. 
own constitution of strengthening their position in the struggle for existence, but man has much. $\mathrm{He}$ gets to himself appliances and instruments, engines and machines, and the dwarf bends the Titan to his will.

(2) If a number of unsociable men were shipwrecked on a Robinson Crusoe island and lived each for himself, a more or less natural selection might occur. In human societary forms, however, there is so much division of labour that, all social sentiment apart, many get a chance whom Nature would not tolerate. As a simple illustration, we may note that the extremely short-sighted are by no means excluded from having a successful career. Even short-sighted dogs and horses survive in domestication. But in wild nature a short-sighted vulture must perish; it cannot get spectacles.

(3) Most animals have to get their own food directly; we cite as great rarities cases like that of the slave-keeping ants, who not only have their food collected but have literally to be fed by their minions. But in mankind the majority get their bread and butter in exchange for something else. Thus types that could not survive in open nature flourish bravely.

(4) Most animals have no inheritance outside of themselves, but in mankind there are many kinds of external legacies. It is only in a very literal sense that the millionaire's son can say, "Naked came I forth," and an inherited title may save a man in the social struggle for existence when neither his body nor his brains could avail.

Some Natural Selection Remains.-While much of the selection that takes place in human 
society is very different from natural selection, and while we systematically thwart the process of natural selection, some still persists in present operation. Let us get a hold of Prof. Karl Pearson's argument. If Darwinism applies to man, "we must have evidence (1) that man varies, (2) that these variations, favourable or unfavourable, are inherited, and (3) that they are selected." (1) "The extent of variation in both man and woman has been measured by the Biometric School in nearly two hundred cases." (2) "There appears no doubt that good and bad physique, the liability to and the immunity from disease, the moral characters and the mental temperament, are inherited in man and with much the same intensity." (3) Careful work has shown that the death-rate in man is partly selective -a function of his constitution. But while there is still some natural selection left at work, it has diminished out of all proportion to the need for it. "Consciously or unconsciously, we have suspended the racial purgation maintained in less developed communities by natural selection."

Sir Ray Lankester has pointed out that the ceaseless increase of man is absolutely peculiar to him of all living species, animal or vegetable, and this is, as Saleeby says, "the source of the major facts of history and the besetting condition of every social problem that can be named at this hour." Man's persistent increase is the more remarkable since he is well known to be a slowly reproducing animal-slowest perhaps, except a few extreme cases like the elephant. The point is this, that whereas most animals have a much higher birth-rate than man, there is none with 
such a low death-rate. The meaning of this is that man has thrown off the natural selection bondage, and insists on saying, and saying successfully, "I will live," when every natural chance is against him."

The Dilemma of Civilisation.-The whole trend of evolution since civilisation began has been to throw off the yoke of natural selection, and we are thus brought face to face with a formidable dilemma. It is impossible to return to a natural selection regime, and yet we have not been able to put an equally effective social selection into operation. No one has stated the dilemma more clearly than Herbert Spencer: "The law that each creature shall take the benefits and the evils of its own nature has been the law under which life has evolved thus far. Any arrangements which, in a considerable degree, prevent superiority from profiting by the rewards of superiority, or shield inferiority from the evils it entails-any arrangements which tend to make it as well to be inferior as to be superior, are arrangements diametrically opposed to the progress of organisation, and the reaching of a higher life."

The Extreme "Laissez-faire" Position.-In face of this dilemma various suggestions have been made. The first is that we should try to restrict our kindness-a kindness which the future may call cruelty. Plato, in his "Laws," recognised the value of the "purgation of the State" which was effected automatically by a stern struggle for existence; and to an interference with natural selection, it is said, much of our sea of troubles is

1 See "The Kingdom of Man," by Sir E. Ray Lankester. (London, 1906.) 
due. Can we not return, then, in some measure to the old regime? Should we not be more guarded in our interference with natural elimination, e.q. in preventing the elimination of weaklings and wasters whose survival and propagation cannot but be a drag on the race?

This suggestion is open to many objections. In the first place, there is the general answer that, as civilisation has involved continuous interference with natural selection, there is danger in the proposal to pursue directly opposite tactics. In the second place, the theoretical suggestion to return to the old natural selection regime is not practicable, partly because of the complexity of our social organisation, which offers so many niches of opportunity to weaklings and wasters, and partly because, without a great change in social sentiment, it is in civilised communities quite impossible not to try to save those to whom Nature would show no mercy. It is likely that we are often cruel in our charity, but we cannot altogether help it.

Besides these general objections to the extreme laissez-faire position, there are many particular objections. Let us take, for instance, the suggestion that we should cease supporting hospitals and the like.

(1) Our attempt to lessen an artificially exaggerated infantile mortality cannot be accurately described as an interference with the order of nature!

(2) Much weakness which we try to strengthen is only superficially, not organically weak; and while we keep alive some who are rotten we save many who only require temporary shelter. One 
enthusiast over bacterial selection says: "The higher the infantile mortality which medicine so energetically combats, the surer is the next generation of being purged of all weak and sickly organisms." But he forgets that the infantile maladies also affect the intrinsically strong and capable, and often weaken them, one might say, quite gratuitously.

(3) Many of the microbes which thin our ranks are very indiscriminate: they remove the wrong people. Prof. Berry Haycraft, in his "Darwinism and Race Progress," points out that the hygienists, in warring against microbes, are eliminating the eliminators who have made our race what it is. This is a very doubtful thesis; but, even if it were true, it is open to us, as the author of course recognises, to put other modes of selection into operation. Can man not select better than bacteria?

Social Surgery.-A second suggestion, which goes a step further than the first, is that we should take more thought for the morrow by deliberately pruning our stock of its diseased buds, especially of those who, if they survive, will be miserable themselves and a cause of misery to others.

Nietsche had the courage to say what many feel, that it would be a kindness to suppress a good many of us. There is no doubt about that, but would it be a permissible kindness? Who is sufficient for these things? It is one thing to discourage in every feasible way-compatible with rational social sentiment-the breeding of weaklings by weaklings; it is another thing to look a fellow creature in the eyes and say, "You must die." Remove weaklings, forsooth! read over the roll of 
them first; might they not say, "Yet we are the movers and shakers of the world for ever, it seems"?

Perhaps the time may come when the noblest social sentiment and a maturer science will agree that this bud and that should not be allowed to open; but the time is not yet. The biologist distrusts social surgery because of his ignorance; the sociologist rejects it because the thought of it makes the foundations of society tremble, and because the social ideal of good citizens is wider than the ideal of good physique; and the practical man will not hear of it because he knows that it is not in us to practise it. Even if the way were clear, it would be like destroying fruits and leaving roots, and securing a fictitious comfort by an entirely artificial method of disowning our social liabilities.

Is Soctal Selection compensating for the Diminution of Natural Selection?-A third suggestion leads us nearer practicable tactics, for it raises an inquiry into the modes of selection which are at present in operation in human societies. How do these compare with natural selection, and how far can they be trusted to effect the purgation of the State?

Whatever form natural selection may takeand it has a thousand-this is always true about it, that the eliminated are eliminated because of some defect in or pertaining to them, " the unlit lamp and the ungirt loin " in some form, and that the survivors survive because of some relatively advantageous quality in or pertaining to them. But there are many selective processes in human society which depend on something else than the 
inherent bodily or mental quality of those selected. Let us consider some illustrations of these.

A German Professor, writing of the enormous mortality of children in large towns, says that all those young lives must pass out because there is no place laid for them at Nature's great table: "Natural selection, don't you know." But the hideous mortality in question has almost nothing to do with Nature's great table or with natural selection. How can one tell? The statistics show, to some extent, what the children die of, and it is, to a large extent, of their parents! For some large towns the deaths of infants have been carefully classified, not only as to the cause of death, but in reference to what the parents do or do not do ; the mortality is double in some classes what it is in others; and this seems certain, that in many cases the selection is not related to the physique of those eliminated. The selection depends, in great part, on the parental standard of comfort and standard of character.

But, it may be said, if there is a differential deathrate, a larger infant-mortality in the less thrifty families, will that not work out right in the long run, since their elimination implies a sifting out of the hereditarily thriftless types? The answer is that, along with the greater mortality, there is associated a greater fecundity, so that the sifting is partially counteracted; moreover, it is not to be supposed that the less thrifty families with high infant mortality are to be thought of as necessarily undesirables; much of the thriftlessness is as artificial as much of the mortality is unnecessary.

Take another instance, which may serve to bring out the difference in method and results between 
social selection and natural selection. In some countries there are posts as foresters and police which are filled by picked men, often by very desirable types physically, mentally, and morally. Here, then, is the setting up of a standard and a rejection of the unfit; and, of course, it works in the right direction. But it is easy to see that it differs from what goes on in nature, and that the issues are complicated. For instance, as a German writer points out, the ineligible were also ineligible for military service. There are no disadvantageous consequences of this; the rejected are spared time and money, they can marry earlier, and so on.

The stress of competition exercises a certain selective influence, but how differently it works from natural selection! It does not necessarily make for the elimination of the unsuccessful; it shifts him. It may compel him into an occupation where his chances of death are lessened. If he is driven out of regular employment altogether, he passes into ranks with a high death-rate, but even then natural selection does not work, for he usually has a large family in the meantime. Thus we see that many processes of differential elimination in human societies turn out, on close inspection, to be very different from natural selection, and this is our whole point at present-that these processes of social selection cannot be trusted, and that nothing is more absurd than to murmur "Survival of the fittest "happening either in the Darwinian sense or in any other.

Reversed Selection in Human Society.Those who are unfamiliar with the biological point of view seem to find it difficult to bear in mind 
that organisms may evolve " downwards" as well as " upwards" in becoming fitter to given conditions. By " upwards" is meant in the direction of a more differentiated and integrated organisation-a more complex and controlled constitutionand we have a habit of regarding ourselves as being very much " up." Now, while it is true that the general trend of evolution throughout the ages has been "upwards," we must not forget that the tapeworm has been evolved as truly as the golden eagle, the one in a dark bypath, the other on the mountain-tops, both well adapted to their conditions of life.

The term "reversed selection" has been applied to cases where, under altered conditions, organisms seem to have gone " downwards," but the term is unfortunate. If by selection a race is becoming better adapted to the conditions of its life, it is to the cold-blooded scientific onlooker immaterial whether the direction of the race-movement is up or down. It is evolution all the same. Considering the movement in relation to a standard, however, we may say that some selective processes make for progress along the lines which have marked the general trend of evolutiongreater complexity, greater control, a fuller, freer life-and that other selective processes make for change in the opposite direction.

Our question now is, are there in human society selective processes at work which make for degeneracy? We all know the difficulty of answering this question, because social processes are so complex and many-sided. Even when the social selection is in part wrong we cannot always stop it. Civilisation is a long-drawn-out compromise. 
In illustration, let us briefly consider the biological aspect of prolonged wars. In his "Human Harvest" President Jordan tells of a man more strenuous than wise, who possessed a stud of horses, which he would make more strong and fleet. "So he rode them swiftly with all his might, day and night, always on the course, always pushed to the utmost, leaving only the dull and sluggish to remain in the stalls. For it was his dream to fill these horses with the spirit of action, with the glory of swift motion, that this glory might be carried on and on to the last generation of horses. There were some who could not keep the pace, and to these, and these alone, he assigned the burden of bearing colts. And the feeble and broken, the dull of wit, the coarse of limb, became each year the mothers of the colts. ... For a time whip and spur made good the lack of native movement . . .; but the current of life ran steadily downward. Each generation yielded weaker colts, rougher, duller, clumsier colts, and no amount of training or lash or spur made any permanent difference for the better. The horse-harvest was bad. Thoroughbred and race-horse gave place to common beasts, for in the removal of the noble the ignoble always finds its opportunity. It is always the horse that remains which determines the future of the stud. In like fashion, from the man who is left flows the current of human history."

Let us observe how Jordan works out his thesis in relation to man. "In the conquests of Rome, $V i r$, the real man, went forth to battle and to the work of foreign invasion; Homo, the human being, remained in the farm and the workshop and begat the new generation." Prof. Seeck, one of the 
historians of the downfall of the ancient world, says that it was due mainly to " the rooting out of the best." "Only cowards remained, and from their brood came forward the new generations." "Wars are not paid for in war times," Franklin said; "the bill comes later." "The Roman Empire," says Seeley, " perished for want of men." There were plenty of people-“" people with too much guano in their composition," as Emerson said; but even Julius Cæsar noted that men were becoming terribly scarce. Prof. Bury writes: "The effect of the wars was that the ranks of the small farmers were decimated, while the number of slaves who did not serve in the army multiplied." The German historian goes on : "Out of every hundred thousand strong men, eighty thousand were slain. Out of every hundred thousand weaklings, ninety to ninety-five thousand were left to survive."

But all that was long ago. So we take up Jordan's "Human Harvest" again, and turn to France-to France, ever young and splendid in spirit. But the birth-rate continues steadily to fall; the average stature is lower by two inches than it was a century ago ; and, as with ourselves, there are other disquieting symptoms. These are doubtless due to a variety of co-operating causes, but can we exclude what one of themselves has said, that "it will take long periods of peace and plenty before France can recover the tall statures mowed down in the wars of the republic and the first empire "?

Year after year Napoleon seized the youth of good stature, and left their bones in great heaps throughout Europe. "You can always fill the 
places of soldiers," he said; but he had eventually to be content with boys. "The mighty swirl of the Moscow campaign sucked in 150,000 lads of under twenty years of age into the devouring vortex"; out of 600,000 who crossed the Niemen to conquer Russia, 20,000 famished, frost-bitten spectres staggered back. It was the rapid succession of skimmings that told. "In less than half a year after the loss of half a million men a new army, nearly as numerous, was forthcoming and the grim roll-call of wasted men, many of them wasted heroes-about half of whom were French-amounted, according to some, to three millions." It is true that glorious France survived all this bleeding, but how impoverished, qualitatively as well as quantitatively! and even a great life-saver like Pasteur could not restore the cubit of stature which the great life-destroyer had lopped off.'

We admit that wars have been necessary and righteous-especially necessary-and that they may be so still, but this opinion does not affect the fact that prolonged war in which a nation takes part is bound to impoverish the breed, since the character of the breed always depends on the men who are left. How else can we understand what has happened so often, that an older civilisation

1 While I plead guilty to disbelief in the biological value of modern war, I do not think this is inconsistent with an appreciation of the soldier's qualities. Who does not admire what Mr. Sandeman describes in his "Uncle Gregory"? (1909) . . . "That quite unmistakable note that you get in a very few people who, in one way or another, have actually accepted death, and are only, so to speak, alive in the meantime. It belongs to the flawless perfection of the military spirit, with its entire detachment from life itself, from selfwill, from fear, and from ease, and from all pretences." 
is overthrown by another less evolved? The only thing a nation dies of is lack of men: and is there not disquieting evidence of the increase of incapables? It is said that we cannot relax one spine of our national belligerence, since we must, at all costs, uphold our national supremacy, having all these teeming millions to feed. But is this not, in part at least, a vicious circle? The question arises whether it is not in great part preoccupation with militarism that is responsible for keeping up our national misery. With a little money saved off belligerence, what might not be done towards social improvement!

An end, then, to the courage and the daring and the chivalry which war has ever kept alive! But can any one seriously believe this? The story of the exploration and conquest of earth and sea is full of heroes, whose work was constructive, not destructive. The man who has grit enough to bring about the afforestation or the irrigation of a country is not less worthy of honour than its conqueror.

Summary of the ARgument.-In early days there was a keen struggle for existence with the forces of nature, with wild beasts, and between fellow-men. There was much natural selection. Gradually the venue changed, there has been a persistent emancipation from the yoke of natural selection, and among civilised peoples it has now but little sway. This exposes our race to the gravest risks of retrogression. To obviate this, some suggest that we should return in part to the old regime; other advise the practice of some social surgery; but neither of these suggestions is feasible-for general tactics at least. It is also 
suggested that there are many forms of social selection in operation which take the place of natural selection; but inquiry-here very superficial-shows that these forms of social selection do not work out as natural selection does, and that some of them have results which are, from the biological point of view, retrogressive.

Constructive Suggestions.-As we are here mainly concerned with getting the biology of the problem clear, we cannot do more than hint at the general policy of betterment. In general, it cannot be other than this-to adhere to and increase those forms of selection which make for the survival of beautiful and healthful surroundings, educative and wholesome occupations, sane and progressive men and women. The first ideal has been called that of Eutopias, the second that of Eutechnics, the third that of Eugenics.' They obviously correspond to the three fundamental categories of biology: Environment, Function, and Organism.

Selection of Eutopias.-Possessed by certain enthusiasms or illusions, a man may gladly liveand perhaps more gladly die-on a cinder-heap; and there is a local patriotism which throws a halo round any home. But deep down in every healthy human being, rooted perhaps in a once closer contact with nature, there is a love of the fresh air, the clean earth, the running brook, the waving trees, the singing birds $-a$ beautiful place, in short, such as even a garden city might afford.

The biological importance of living in beautiful

1 The first two by Prof. Patrick Geddes, the third by Sir Francis Galton. 
surroundings is inestimable. It makes for health of body and brain ; it awakens long-dormant buds ; it fills up the life with wholesome delights; it produces pleasant modifications on the individual; and who can tell how its potent messages may travel by "the wireless telegraphy of ante-natal life"?

All this is familiar, yet are we not slow to adopt a resolute policy of securing one of the really good things in life-a Eutopia? Every one knows that this is no Utopia, if we can only make up our minds to live more in the present and less in the future.

Selection of Healthful Occupations. - Within the hands of all men of good-will there is a powerful instrument of progress, technically known as "the criticism of consumption." It is one of the most effective factors in amelioration, especially as regards the selection of healthful occupations. Perhaps more might be made of it if the strategy involved was more generally recognised. When we discover that certain articles are socially injurious, bad for the maker, bad for the buyer, we should not buy them, but get instead something which it was good for a man to make, and good for us to have. Now, if we do this consistently and keep at it unwaveringly, and get others to do the same, we will, if we keep the selection a-going long enough, often enough, stringently enough, put an end to an ugly article and an injurious occupation. The process is never quick enough to be unjust or cruel, as the swings of fashion often are. Apply this consistent selection to favouring wholesome people, not wasters, constructive occupations, not destructive ones, beautiful places, not ugly ones-and we have 
returned to Nature's method on a higher turn of the spiral. Even natural selection would favour the survival of qualities like healthfulness; it is for a rational social selection to continue the endless task.

Eugenic Selection.-The third aspect of the biological ideal towards which it is necessary to select is the improvement of the human breedthe ideal of eugenics. There is perhaps no nobler enthusiasm, and while some of the enthusiasts are occasionally carried away by their zeal, we must not reject the quiet wisdom of a veteran general like Sir Francis Galton, because of the extravagant utterances of subalterns. But, apart from subalterns, it is not easy for even expert students possessed by a worthy enthusiasm to keep the complex issues in perspective. Illustrations may be found, for instance, in the excellent exposition of the eugenist argument which Dr. Saleeby has given us in his "Parenthood and Race-Culture" (1909). "The idea of selection for parenthood as determining the nature, fate, and worth of living races is Darwin's chief contribution to thought, and finds in eugenics its supreme application."

"The question is not whether a given proposal is socialistic, individualistic, or anything else, but whether it is eugenic. If it is eugenic, that is final. To this all parties will come, and by this all parties will be judged. . . . I claim for eugenics that it is the final and only judge of all proposals, and principles, however labelled, new or old, orthodox or heterodox." This is forcibly put, but it illustrates the difficulty of appreciating the complexity of the human situation. The eugenic ideal is the breeder's ideal-vigorous organisms, and the 
eugenist's method is the breeder's methodselection for parenthood; but the difficulty is that we have to deal with larger ends than men, we cannot ignore the social framework and a whole hierarchy of social integrates. Even if we ignore them in theory, they will be too strong for us in practice. The eugenic programme must submit to social criticism, which will not be merely theoretical.

Let us recall some of the facts which bring the importance of the eugenic ideal home to us. One quarter of the married people of this country, one-sixth to one-eighth of the total adult population, Prof. Karl Pearson tells us, produce 50 per cent. of the next generation. "How essential it is for the maintenance of a physically and mentally fit race that this one-sixth to one-eighth of our population should be drawn from the best, not the worst stocks!" "We cannot recruit the nation from its inferior stocks without deteriorating our national character." This is the argument which Pearson so powerfully develops.

Of course the statistics of diminishing birth-rate require careful treatment by experts. The average annual birth-rate per 1,000 has fallen from $35 \cdot 35$ in 1876-80 to $28 \cdot 10$ in 1901-1905, but against this we must notice that the death-rate has also fallen from 20.79 to 16 . The ominous fact is that it was by a gradual but persistent diminution of natality that France reached her present state of a death-rate in excess of the birth-rate.

Yet Prof. Pearson's point is not so much the general diminution, but the differential diminution. In Britain the diminution seems greatest where it is least wanted, namely, among the workers of 
the community and among the more far-seeing and provident classes. French statistics show that the birth-rate is less in proportion to the standard of comfort. At present the birth-rate in France is said to be below the death-rate in all sections except manufacturing centres. Among academically educated Americans the average number of offspring is less than two.

There seems no doubt as to the ominously rapid multiplication of the relatively unfit. "Degenerate stocks under present social conditions are not short-lived; they live to have more than the normal size of family." They have at present a better chance to survive and multiply than ever before. Especially in Britain do the weeds spread quicker than the flowers. The feeble-minded are prolific; certain kinds of degenerates are prolific; the thriftless are prolific. From a study of $150 \mathrm{de}-$ generate families, Dr. Tredgold found that the average number of children in a family was $7 \cdot 3$, not including those still-born, instead of the normal average of four.

Let us be as generous as we can. An unpromising bud may burst into a fine flower: John Bunyan's father was a tinker. But every one is agreed that there should be no breeding from epileptics, lunatics, paralytics; should not this list be added to ? ${ }^{1}$ Is it not a pity, for instance,

1 In his Robert Boyle Lecture on "The Scope and Importance to the State of the Science of National Eugenics" (2nd ed., 1909) Prof. Karl Pearson says: "If we realise the antinomy which Eugenics brings to our notice between high civilisation and racial purgation, we ask: How can the dominant fertility of the fitter social stocks be maintained when natural selection has been suspended ? I do not think any wise man would be prepared with a full answer to this question to-day. There is no sovereign remedy 
that we should look with favour on the marriage of deaf-mutes? Let us admit that many of the unfit may be only modificationally unfit-illnourished plants in the crowded garden-requiring only new soil. Many criminals are simply anachronisms-people out of time and out of placewho need, not incarceration, but transplantation. Cure the poacher by making him a collector. But this will not cover all.

Let us admit, too, that very bad stock-such as the uncontrolled alcoholic type-tends to work itself out. Taints may be swamped, just as excellences often are.

Prof. Biffen has bred into a good stock of corn the quality of immunity to rust which a poor stock had, and perhaps-perhaps-the future has in store for us analogous ways of getting a clean thing out of an unclean in human kind.

Meanwhile, what is to be done? Many gentle measures are possible-fostering pride of race, encouraging the marriage of desirables, developing

for degeneracy. Every method is curative which tends to decrease the fertility of the unfit and to emphasise that of the fit. We may find it difficult to define the socially fit, although physique and ability will carry us far ; but when we turn to the habitual criminal, the professional tramp, the tuberculous, the insane, the mentally defective, the alcoholic, the diseased from birth or from excess, there can be little doubt of their social unfitness. Here every remedy which tends to separate them from the community, every segregation which reduces their chances of parentage, is worthy of consideration. . . Is not something more to be insisted upon with regard to the increase of good stock ? . . A clean body, a sound if slow mind, a vigorous and healthy stock, a numerous progenythese factors were largely representative of the typical Englishman of the past; and we see to-day that one and all these characteristics can be defended on scientifio grounds ; they are the essentials of an imperial race," 
prejudice against the marriage of undesirables, fuller recognition of woman's rights, both as to mating and maternity. For another step we shall soon be ready-a form of rational social selection - the institution of a sort of marriage test and some attempt to prevent the multiplication of those who, by their own inefficiency, have fallen back on the community for support.

Social sentiment will not permit social surgery, which is probably just as well; but we cannot be proud of our tender-heartedness when we reflect on what we do permit in the way of slow murder in the present and in the way of keeping up misery for the future.

In this connection Mr. Whetham writes: "When we have built and endowed schools and hospitals, pulled down insanitary dwellings and thrown open green spaces, brought in fresh water and uncontaminated milk, vaccinated babies and destroyed tuberculous cows, when we have established a cult of fresh air, a whole science of naturestudy, and the paraphernalia of the simple lifewe are brought up sharp against a stone wall. We are informed that our unemployed are chiefly unemployable, that the provision of more lunatic asylums is of greater urgency than the provision of increased school accommodation, that a whole class of feeble-minded individuals has grown up and is totally unprovided for, that ability is more difficult to find and mediocrity shows no tendency to rise, that general physical deterioration may be knocking at our doors-in short, in spite of all our efforts, matters are conceivably worse than when we started, and an uncomfortable feeling comes that "in spite of " might possibly be more 
correctly written "on account of." 1 Unless we are prepared to do nothing, saying with Sir Boyle Roche, "What has posterity done for us ?" then we must try " to replace Nature's selective death-rate by a selective birth-rate." 2 In any case, we can share in forming public opinion.

Whymper, in his "Scrambles among the Alps," says some forcible things about the marriage-the Church marriage-of cretins who swarm in the valley of Aosta and elsewhere. For many generations the strongest and healthiest peasants had to go to the wars; the idiotic and goitrous were left. The disease may not be in itself hereditary, but susceptibility to it is; and in one village it was said that all had a goitre except the young priest. In any case the cretins of Aosta thrive and multiply, and the consummation of the tragedy is that the Church solemnises their union. ${ }^{3}$ At one end we have the celibacy of the clergy-often remarkably fine peasant thinkers and dreamers-and the celibacy of the most gentle and spiritual womena segregation from the race of some of its finest types-at the other end the blessing of the goitrous pair. Which things are a parable.

Some sneer at eugenics as obtruding into the sanctity of human relationships the counsels of the farm-yard; but reflection will show that the sanctity is heightened, not lessened, when the solemn issues are realised.

It is likewise quite certain that, whether we

1 "Inheritance and Sociology," by W. C. D. Whetham, in The Nineteenth Century and After (No. 363, Jan. 1909), pp. 74-90.

2 Saleeby, "Parenthood and Race Culture" (1909).

3 Of course one hopes it has been changed in the last few years. It was true quite lately. 
have celibate fellowships at the colleges, or advertise for a gardener "without encumbrances," or dismiss women teachers on marriage, or refrain from marrying till we have ten times the income our father had when he begat us-the list can be continued ad nauseam-we are ignoring the fundamental laws of good breeding or eugenics, just as we are when we refrain from condemning the marriage of the feeble-minded or from protesting against certain charitable devices which create more misery than they relieve.

By way of illustration, let us think for a moment of China-a country of extraordinary interest to the biologist. It has kept up a continuity of state organisation and culture for four thousand years; the people have big brains and marvellous physique; they are very fertile, the aristocracy not less than the unlearned; they have genuine old families, going back to Confucius, and not decadent; they are in many ways very moral; and so on.

Now there are many reasons for all this, but two strike the biologist: (1) To an extent quite impossible for us, the Chinese allow natural selection in famine and disease, etc., to go on without hindrance. Here we cannot imitate them. (2) For thousands of years, on the other hand, the Chinese have paid great attention to breeding, to family histories, to family life, to family feeling, and honour of ancestry. Ages ago they used to send a policeman to eligible bachelors with a notice to marry. In their positive eugenic practices the Chinese are worthy of our imitation.

And what is the conclusion of all this talk? Nothing new. More and more our human societies 
SELECTION : ORGANIC AND SOCIAL 237

free themselves from natural selection, and it behoves us to make sure that some rational winnowing takes the place of the automatic process of nature. There are many processes of social selection going on, some for evil and some for good. They require to be sternly criticised, especially as those that are for good do not seem to be getting any grip of the organic qualities of the breed.

We must take more thought of the improvement of our breed, not only for its own sakefor healthfulness is as fundamental as virtue is supreme-but also lest we become involved in some terrible inter-societary struggle and findlike Samson-when we arise and go out and shake ourselves, as at other times before, that our strength has gone from us in our sleep. 

REPRESENTATIVE BOOKS ON DARWINISM 

UC SOUTHERN REGIONAL LIBRARY FACILITY

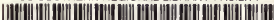




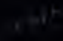

,

(4) 